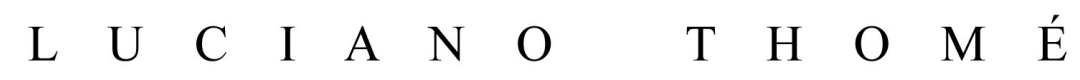

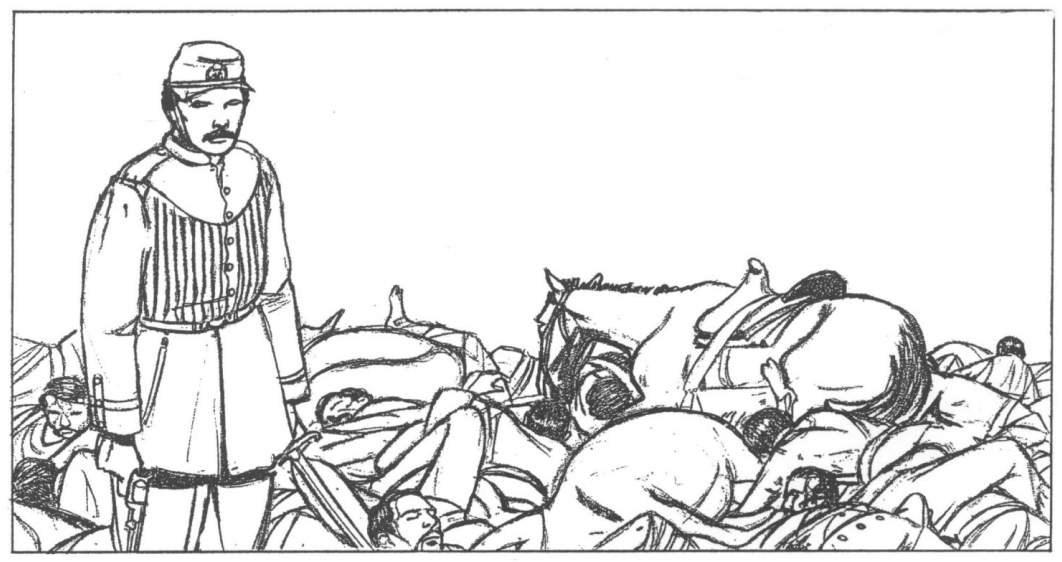

H ISTÓRIAS e m Q UADRINHOS e DIDÁ TICA da HISTÓRIA no BRASIL

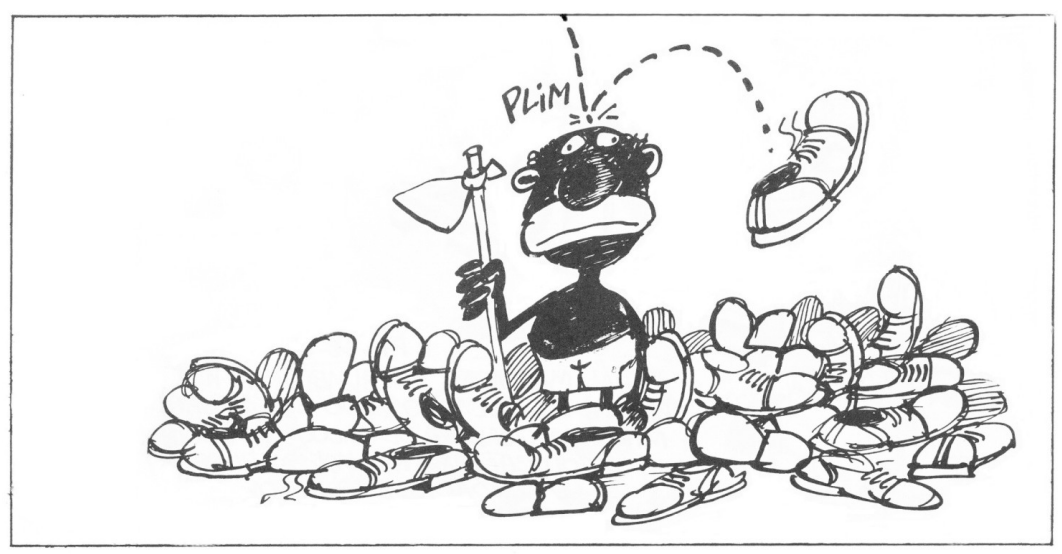

A f o r m a qua d r i n ír t i c a e o c o n h e c i me nto his tór r c o

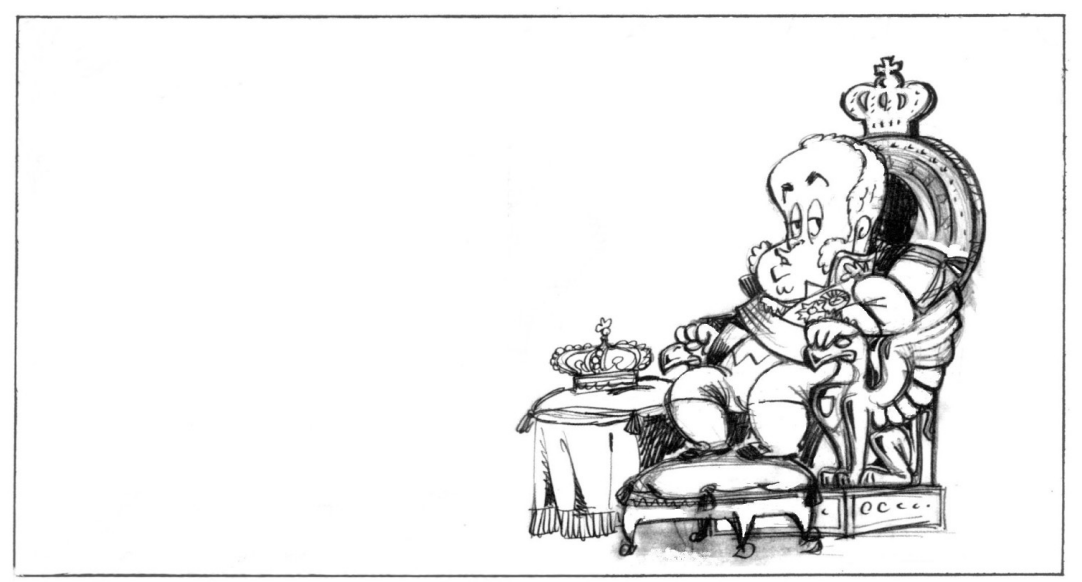

E C A - U S P

S ã o $\quad P$ a u 1 o -2 o 12 
LUCIANO THOMÉ
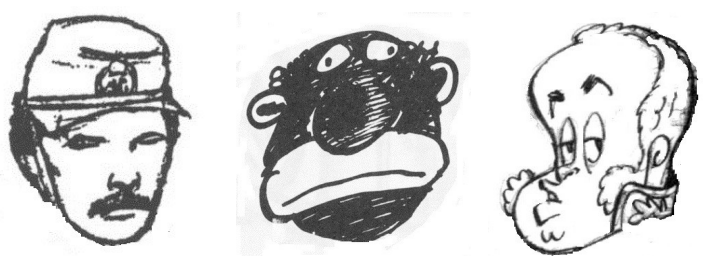

HISTÓRIAS EM QUADRINHOS E DIDÁTICA DA HISTÓRIA NO BRASIL: a forma quadrinística e o conhecimento histórico

São Paulo 
LUCIANO THOMÉ

\section{HISTÓRIAS EM QUADRINHOS E DIDÁTICA DA HISTÓRIA NO BRASIL: a forma quadrinística e o conhecimento histórico}

Dissertação apresentada à Escola de Comunicações e Artes da Universidade de São Paulo, como exigência parcial para obtenção do título de Mestre em Ciências da Comunicação.

Área de Concentração: Interfaces Sociais da Comunicação.

Linha de Pesquisa: Comunicação e Cultura

Orientador: Prof. Dr. Waldomiro Vergueiro

São Paulo 
Autorizo a reprodução e divulgação total ou parcial deste trabalho, por qualquer meio convencional ou eletrônico, para fins de estudo e pesquisa, desde que citada a fonte.

Catalogação da Publicação

Abraão Antunes-Silva

CEDOC Ação Educativa

Thomé, Luciano

Histórias em Quadrinhos e Didática da História no Brasil: a forma quadrinística e o conhecimento histórico / Luciano Thomé; Orientador: Waldomiro Vergueiro. São Paulo, 2012.

122 f. : il.

Dissertação (Mestrado) ECA/USP, 2012.

1. História em Quadrinhos 2. História (Didática) 3.Quadrinho Histórico 
Nome: THOMÉ, Luciano

Título: Histórias em Quadrinhos e Didática da História no Brasil: a forma quadrinística e o conhecimento histórico.

Dissertação apresentada à Escola de Comunicações e Artes da Universidade de São Paulo, como exigência parcial para obtenção do título de Mestre em Ciências da Comunicação.

Aprovado em: $/ 2012$

Banca Examinadora

Prof. Dr. Instituição:

Julgamento: Assinatura:

Prof. Dr. Instituição:

Julgamento: Assinatura:

Prof. Dr. Instituição:

Julgamento: Assinatura: 
Aos meus pais

e meus irmãos

Aos "meus amiiigos!"

A Dessa

ma déesse 


\section{AGRADECIMENTOS}

Agradeço ao professor Waldomiro Vergueiro por acolher e orientar esta pesquisa.

Aos professores Marcos Silva e Paulo Ramos por suas sugestões e observações críticas.

Aos amigos e colegas Abraão Antunes-Silva, Andressa Goulart Crossetti, Carlos Torcato, Felipe Thomé, Maracajaro Mansor e Victor Ghiraldini por suas contribuições.

À Escola de Comunicações e Artes e Universidade de São Paulo por seu acolhimento e à instituição de fomento acadêmico CNPQ/CAPES, pela concessão de bolsa de pesquisa para a sua realização. 


\section{RESUMO}

O presente estudo analisa as relações entre a forma quadrinística e o conhecimento histórico científico tomando os casos específicos das obras Adiós, Xamigo Brasileño (...); Redescobrindo o Brasil; e D. João Carioca (...). Tal análise se faz por meio das metodologias das teorias comunicativa das histórias em quadrinhos e da didática da história em relação interdisciplinar.

Palavras-Chave: História em Quadrinhos; História (Didática); Quadrinho Histórico;

THOMÉ, L. Histórias em Quadrinhos e Didática da História no Brasil: a forma quadrinística e o conhecimento histórico. 2012. 118 f. Dissertação (Mestrado) - Escola de Comunicações e Artes, Universidade de São Paulo, São Paulo, 2012. 


\section{ABSTRACT}

The present research analyzes the relationship between sequential art form and scientific history knowledge in the specific case studies of the works Adiós, Xamigo Brasileño (...); Redescobrindo o Brasil; e D. João Carioca (...). Such analysis is made by interdisciplinary methods informed by communication theory on sequential art and history didactic theory.

Keywords: Sequential Art, History (Didactic), Historical Comics; 


\section{SUMÁRIO}

1.INTRODUÇÃO 10

2. QUADRINHOS COMO FORMA DE COMUNICAÇÃO ESTÉTICA 13

2.1. Quadrinhos como forma 13

2.2. Quadrinhos como comunicação e como estética 17

3. COMUNICAÇÃO ESTÉTICA DO CONHECIMENTO HISTÓRICO 27

3.1. De outras formas de comunicação da história 30

3.1.1. Lukács e o romance histórico 31

3.1.2. Peter Burke e a pintura histórica

4. COMUNICAÇÃO QUADRINÍSTICA DO CONHECIMENTO HISTÓRICO 36

5. ESTUDOS DE CASOS DIDÁTICO-HISTÓRICOS 39

5.1. Adiós, Xamigo Brasileño: o quadrinho histórico de André Toral 40

5.1.1. O quadrinho histórico como forma científica de arte (...) 43

5.1.2. O quadrinho histórico como derivação do romance histórico 45

5.1.3. O quadrinho histórico como reconstituição histórica ou historiografia 52

5.1.4. Esquadrinhando Adiós, Xamigo (...) 58

5.1.4.1. Realismo visual 59

5.1.4.2. Representação da cultura material 65

5.1.4.3 Símbolos visuais $\quad 69$

5.1.4.4. Representação do monumento histórico $\quad 70$

5.1.4.5. Crítica do relato oral e metalinguagem histórica 77

$\begin{array}{ll}\text { 5.1.4.6. Representação do imaginário } & 78\end{array}$

5.1.4.7. O quadrinho histórico em sua dialética (...) 79

5.2. A comunicação cômica do conhecimento histórico 84

5.2.1. A coleção Redescobrindo o Brasil como cartunismo histórico 85

5.2.1.1. Alegorias na coleção Redescobrindo o Brasil 88

5.2.1.2. Coleção de quadrinhos?

5.2.2. D. João Carioca (...): o quadrinho histórico de Schwarcz e Spacca 100

5.2.2.1. Da representação caricatural de personagens históricos 101

5.2.2.2. A referência documental em D. João Carioca (...) 104

5.2.2.3. O problema do anacronismo 110

6. CONCLUSÃO 114

$\begin{array}{ll}\text { BIBLIOGRAFIA } & 118\end{array}$ 


\section{INTRODUÇÃO}

O presente estudo, intitulado "Histórias em quadrinhos e didática da história no Brasil: a forma quadrinística e o conhecimento histórico", parte do interesse em um fenômeno cultural que, embora não constitua inteiramente em uma novidade (remonta a meados do século $\mathrm{XX}$ ), conseguiu destaque significativamente na última década, a primeira do XXI: trata-se da produção de histórias em quadrinhos concernidas à comunicação do conhecimento e da cultura histórica no Brasil. O fato possui notáveis implicações em diversos âmbitos da nossa cultura, dos quais se destacam o desenvolvimento da produção quadrinística nacional, por um lado, e o da prática comunicacional da cultura e do conhecimento histórico, por outro. É basicamente sobre essa proeminente (e promissora) relação entre histórias em quadrinhos e didática da história que dissertaremos nas páginas seguintes.

A inserção acadêmica de nossa pesquisa parte da área das ciências da comunicação, haja vista que está centrada sobre um processo comunicacional. Seu desenvolvimento, todavia, abrange um campo de conhecimentos mais vasto. Imbricado em diferentes especialidades científicas e estéticas é, por essa razão, um trabalho inevitavelmente interdisciplinar. A seguir buscamos situar nossa inserção nessa intersecção de disciplinas. Para além das complexidades epistemológicas relativas às especificidades das áreas do conhecimento a que nossa pesquisa deve se reportar cabe a ressalva histórica de que a tão propagada interdisciplinaridade é, em nossa opinião, menos uma novidade epistemológica revolucionária que um mecanismo paliativo contra certas limitações acarretadas pela exacerbação das fronteiras de especialização científicas no avanço da divisão social do trabalho sob o capitalismo concentrado. Enfim, em sentido positivo, as repartições do conhecimento auxiliam no aprofundamento de conhecimentos específicos; em sentido negativo, tendem à alienação do mesmo em relação à totalidade cognoscível e a suas relações internas.

Por "comunicação", tomada em seu sentido moderno mais geral (WILLIAMS, 2007, p. 102), entendemos o ato de tornar comum, de compartilhar socialmente uma cultura. Em um segundo momento, estamos interessados no estudo da comunicação da uma cultura particular, 
a saber, a cultura histórica. Essa é a competência da didática da história, entendida como disciplina teórico-crítica da historiografia que avalia suas formas e funções em relação ao conhecimento histórico (RÜSEN, 2007). A partir da didática da história, erguem-se os problemas relativos à formatação comunicativa da cultura e do conhecimento histórico que nos dizem respeito.

A comunicação, por sua vez, se faz por meio de formas historicamente particulares. Podemos identificar, a título de síntese, a forma com a linguagem da comunicação. Nesse caso, a linguagem particular que nos interessa é a das histórias em quadrinhos. A partir da particularidade formal de nosso objeto genérico, os quadrinhos, situamo-nos na tradição de estudos das mesmas que enfatizam sua autonomia (SANTOS, VERGUEIRO, 2006; RAMOS, 2009). Baseamo-nos em um método de análise intrínseca das formas por meio das quais o conhecimento histórico é comunicado em quadrinhos. Enfatizar a autonomia dos quadrinhos, entretanto, não implica na ausência de um diálogo com outras formas de linguagem tais como a literatura, a pintura, o cinema, etc. Tendo em vista esse diálogo formal, lançamos mão também de análises provenientes de outras áreas do conhecimento estético, sejam elas relativas a formas específicas ou às artes em geral.

A comunicação não se dá apenas por meio de formas específicas, mas entre sujeitos históricos concretos. É em direção a estes que vão de encontro os objetivos sociais de nossa dissertação. Dentre eles, identificamos como principais os quadrinistas e os historiadores. Essa relação entre a produção de quadrinhos e de conhecimento histórico é a mais importante para nossa pesquisa. Por isso escolhemos como fonte preferencial de nosso estudo histórias em quadrinhos cuja produção relaciona-se com a produção acadêmica do conhecimento histórico. Cabe aqui a ressalva de que tal produção não é exclusividade da academia. Se elegemos tais fontes, é porque nelas tais relações são mais evidentes.

Há ainda a área de convergência da educação, que vem se fazendo cada vez mais presente também nos estudos em comunicação por conta da interface gerada no encontro das duas áreas na realidade social, identificadas particularmente através da tensão entre a instituição escolar e os meios de comunicação massivos. Nesse sentido, os quadrinhos didático-históricos são compreendidos como um segmento da comunicação social cujos objetivos e motivações são preferencialmente de ordem educacional. Esse âmbito social, 
contudo, refere-se mais à recepção que à produção dos quadrinhos que comunicam conhecimentos históricos.

Nosso estudo, em síntese, tem por objeto último a produção de histórias em quadrinhos que comunicam o conhecimento histórico no Brasil. Mais especificamente, tem como escopo a forma desta comunicação em suas particularidades formais, sejam elas relativas à técnica e à linguagem quadrinística além de seus meios e suportes materiais. $\mathrm{O}$ problema de pesquisa que buscamos resolver, portanto, pode-se resumir na interrogação: de que forma os quadrinhos comunicam o conhecimento histórico no Brasil?

Os capítulos da dissertação estão organizados da seguinte maneira. No segundo capítulo que se segue a essa introdução, Quadrinhos como forma de comunicação estética, apresentamos nosso objeto de estudo por meio de reflexões acerca de suas características intrínsecas e de sua inserção social. No terceiro capítulo, Comunicação estética do conhecimento histórico, debruçamo-nos sobre outras formas de arte que comunicam a cultura histórica com o objetivo de traçar um modelo genérico que identifique em suas linhas gerais o nosso objeto de estudo, o quadrinho histórico. No quarto capítulo, Comunicação quadrinística do conhecimento histórico, inserimos um breve comentário sobre o contexto atual e algumas raízes históricas da produção quadrinística didático-histórica. Por fim, no quinto e último capítulo, analisamos pormenorizadamente casos de produção de quadrinhos que se vinculam diretamente com o conhecimento histórico acadêmico. 


\section{QUADRINHOS COMO FORMA DE COMUNICAÇÃO ESTÉTICA}

\subsection{Quadrinhos como Forma}

"Quadrinhos são quadrinhos"

Paulo Ramos

É consensual entre seus estudiosos que as histórias em quadrinhos constituem uma forma autônoma (RAMOS, 2009, p. 18). São justamente as particularidades do meio que lhe conferem um nome próprio. Partimos da terminologia para enxergar seus traços definidores para, em seguida, compreender o significado histórico de seu desenho. A seguir, buscamos decifrar algumas definições genéricas dessa forma e seus significados que, para além de designar estruturas de sua linguagem ou recursos técnicos, bem como seus suportes materiais, trazem também consigo, portanto, conteúdos históricos.

Iniciemos pelo termo "quadrinhos", que é uma redução evidente da nomenclatura mais utilizada no Brasil para se referir ao meio específico de narrativa sequenciada através de textos visuais e verbais integrados (sendo que a presença deste último não é uma regra). Como é um nome composto sua repetição textual costuma ser reduzida pelo apelido de "quadrinhos" ou pela sigla mais especializada "HQ". Preferimos o primeiro por sua carga mais calorosa e afetiva para com o meio. Escolhas sentimentalistas à parte, aderimos a ele também enquanto construto linguístico mais popular e espontâneo que o outro. A expressão mais comum, nesse caso, favorece à comunicação.

O termo "história em quadrinhos" que se desenvolveu no Brasil possui seus paralelos populares em outros países no mundo. Um dos mais próximos em termos de raiz semântica é o fumetti italiano, que também se apega a um traço comum da linguagem visual do meio, no caso o balão de fala dos personagens, que por lá é identificado como uma fumaça. A despeito das alegações de que nem toda história em quadrinho possua balões ou seja sequenciada em pequenos quadros não diminui sua aceitação e compreensão por parte da sociedade. Há outros paralelos. Na Argentina o meio é conhecido por historieta, termo diminutivo que também 
carrega certo tom carinhoso, possivelmente devido ao fato de o mesmo ter sido identificado em praticamente todo o mundo e na maior parte de seu desenvolvimento ao longo do século XX como leitura infantil, muito embora não tenha sido assim em sua origem.

Os quadrinhos mais sofisticadas em termos de técnica e temática quase sempre se dirigiram ao público adulto. Poderíamos apontá-los como constituindo uma vanguarda quadrinística. Como é próprio das vanguardas, sua inserção social é restrita e suas expressões se mantiveram quase sempre na obscuridade e continuam bastante desconhecidas do grande público. Tal ignorância resulta em diversos preconceitos a respeito do meio, o que faz muitos disseminadores dos quadrinhos, particularmente quadrinistas às voltas com ambições artísticas mais elevadas, a se voltarem contra os termos "infantilizadores" por serem supostamente inadequados para a construção de uma imagem mais "séria" para os quadrinhos.

Recentemente surgiu outro substantivo para se referir aos quadrinhos nos Estados Unidos. Associado ao florescimento de obras quadrinísticas com maior número de páginas (em média de uma a três centenas) e veiculada sob o tradicional formato gutemberguiano do livro encadernado (em oposição ao formato "revistinha" dos comics e dos gibis). Quadrinhos já eram publicados nesse suporte, principalmente na Europa, sob a denominação de "álbum". A partir do mercado de quadrinhos norte-americano, entretanto, surge o termo graphic novelliteralmente, "romance gráfico". Os espaços de sua comercialização acompanharam a mudança no formato do suporte, transferido-se das bancas de jornal para as livrarias. Seu uso possui uma destacada intenção mercadológica - no caso, reconquistar um público consumidor adulto afirmando a "seriedade" de tais obras (VERGUEIRO, 2007). O termo norte-americano e em inglês vêm inclusive sendo reproduzido no Brasil pelas editoras nas capas e contracapas de suas traduções, agregando aí o valor fetichista que a língua inglesa logrou na publicidade nacional. Até aí nenhuma novidade; ou melhor: apenas a novidade conformada pela moda, algo tipicamente moderno. De todo efeito, o sucesso comercial dos "romances gráficos" abriu as comportas de investimento de capital por parte da indústria editorial em obras quadrinísticas de maior fôlego e que atingem maior profundidade. A menor ou maior proximidade com a forma literária do romance, entretanto, não se deve tanto à semelhança do suporte material e sim aos recursos técnicos e linguísticos apropriados ou não de sua tradição.

Dentre as definições para os quadrinhos, poucas surgiram de uma preocupação teórico-conceitual. É o caso do termo "arte sequencial” cunhado pelo quadrinista Will Eisner 
em sua obra de reflexões sobre a técnica dos quadrinhos (EISNER, 2001). Lembremos que o termo corrente para designar o meio nos Estados Unidos é comics, visto que o surgimento dos quadrinhos em sua forma mais ou menos reconhecível hoje em dia se dá justamente no contexto da consolidação da imprensa de massa naquele país e está associada a charges, cartuns e tiras de temática cômica. Para nós, o mais interessante do conceito artificialmente desenvolvido por Eisner é justamente que ele busca ampliar o alcance histórico do fenômeno limitado pelo termo comics. Ele insere os quadrinhos - ou melhor, transforma a "arte sequencial" - em um fenômeno estético de origens muito mais remotas. Ao estender a abrangência histórica de seu meio, Eisner enfatiza a continuidade no desenvolvimento de uma forma que em ultima instância é determinada pela técnica de narrativa visual em sequência de imagens estáticas (o que a diferencia do cinema) e possui como denominador comum a antiquíssima técnica do desenho e seus correlatos, como a pintura, o mosaico, o alto e o baixo relevo. Assim, a representação dos feitos de um imperador romano na Coluna de Trajano ou a do martírio imposto a um rebelado contra o mesmo império amplamente difundida em muitos templos cristãos nos vitrais da Via Crucis consistiriam nos primórdios da arte sequencial - isso para não citar exemplos de arte rupestre paleolíticas e neolíticas que aparentemente representam fatos sucessivos em sequência imagética.

Por outro lado, a substituição de "quadrinho" por "arte sequencial” (“comics” por "sequential art") pode obscurecer a importância das formulações espontâneas, dadas no calor do momento, para a compreensão histórica a posteriori. Em palavras mais diretas, o termo "arte sequencial" obscurece a historicidade do fenômeno quadrinístico em toda sua especificidade e imersão no contexto social que assim o nomeou e que ainda mantém muito de seus traços. Para citar apenas um exemplo, a palavra "quadrinho" pode ser tomada como expressão de um preconceito estético, a saber, de que "quadrinhos são coisa de criança" ou uma forma de arte "menor" (ou nem isso). A maior preocupação de Eisner na procura de um conceito era possivelmente contrapô-lo a tais preconceitos. Não por acaso se vale da palavra "arte". Tal preocupação se insere em uma discussão, hoje praticamente superada, acerca do estatuto estético dos quadrinhos. A sobreposição conceitual sobre a matéria histórica consistiria em um anacronismo fundamentalmente errôneo, que prejudica a melhor aproximação do conhecimento histórico sobre tais expressões culturais? Não acreditamos ser exatamente esse o problema, pois os conceitos desenvolvidos a posteriori possuem justamente essa finalidade de dar conta de objetos para os quais não havia tais instrumentos ideais. 
Os termos "arte sequencial" e "história em quadrinho" enquanto instrumentos teóricos, aquém do conteúdo histórico já explanado, divergem em suas adequações e inadequações principalmente no que se refere justamente à "anatomia" da forma em questão. Discute-se, por exemplo, se as expressões culturais que se quer abarcar tem de ser todas seqüenciais: charges e cartuns, compostos de uma imagem apenas, podem ser considerados gêneros quadrinísticos? A discussão da forma, de sua estrutura, características, etc. não são em nenhuma hipótese irrelevantes. No nosso caso, entretanto, não são cruciais para a eleição de algum termo. O conteúdo de tal ou qual palavra nesse caso nos interessa mais como fonte de reflexão histórica acerca de seus significados sociais que como instrumento teóricometodológico, função para a qual nenhum se sobressai.

"Quadrinhos", portanto, comumente designa o fenômeno simultaneamente estético e comunicacional no qual antigas estruturas linguísticas e recursos técnicos confluem nos contemporâneos meios de comunicação de massa. Seus suportes materiais, portanto, condicionam e são condicionados pela possibilidade de reprodutibilidade técnica e consequente indústria cultural desencadeadas pelo desenvolvimento avançado do capitalismo. É, por isso, um fenômeno historicamente recente. A seguir, trataremos justamente dessa sua condição relacionando-a com um debate pertinente a tal compreensão. 


\subsection{Quadrinhos como Comunicação e como Estética}

Este sub-capítulo reflete acerca das relações possíveis para pensar os quadrinhos a partir do debate teórico empreendido no pensamento estético do século XX a propósito da chamada crise da cultura. Evocamos esse debate - especialmente caro à tradição marxista de crítica cultural do período a qual demos especial atenção - relacionando-o ao desenvolvimento sincrônico (e paralelo) das histórias em quadrinhos. Sua relevância deve-se ao fato de que pode pode contribuir para compreender o fenômeno particular dos quadrinhos na totalidade do desenvolvimento histórico em que se insere.

Um dos novos dados da nossa realidade cultural atual é, portanto, esse meio de comunicação, essa forma de arte, chamada história em quadrinhos. Para melhor entender esse objeto específico necessitamos uma teoria específica, e por isso é importante a elaboração de uma teoria dos quadrinhos. Essa teoria não pode, entretanto, estar alheia a uma teorização mais abrangente o possível da totalidade da realidade histórica. Isso é, deve estar inserida em uma teoria maior e assim sendo os limites de sua autonomia se referem principalmente ao cuidado epistemológico de não torná-la alienada acerca dessa totalidade. Por isso elegemos a tradição marxista desse debate que consideramos a mais adequada para essa compreensão totalizante e dialética desse pormenor da nossa cultura chamado quadrinho. Uma das principais contribuições que esse resgate teórico pode trazer se refere não apenas à compreensão das condições históricas mais gerais que determinam a formação das histórias em quadrinhos, mas também a suas implicações artísticas e científicas - seus usos perceptivos e cognitivos - e consequentemente políticas cujas funções sociais - sejam reacionárias ou revolucionárias - podem ser próprios da forma quadrinística em nosso contexto.

A título de síntese, uma proposição interessante acerca dessa discussão é empreendida por Umberto Eco, que definiu seus dois partidos entre "apocalípticos" e “integrados". Entre os apocalípticos, no caso do debate que situamos, estariam aqueles que criticavam as transformações culturais como sendo causa e efeito de retrocesso ou decadência intelectual e cultural. Figurariam nesse partido Lukács, Adorno e Horkheimer. Entre os integrados estariam aqueles que observavam essas mesmas transformações positivamente, enfatizando especialmente certa tendência à democratização da cultura por meio da ampliação do alcance material de seus meios. Figurariam aí Walter Benjamin e Bertolt Brecht. 
Cabe lembrar que tal debate se deu inicialmente no âmbito da filosofia estética antes de as ciências da comunicação afirmarem sua autonomia institucional. O processo de transferência ou apropriação desse debate, como também veremos nesse capítulo, relaciona-se com os desenvolvimentos históricos das artes no século XX, que passaram a ser observadas, dadas os desenvolvimentos históricos que ampliaram seu alcance social, principalmente em sua função comunicacional.

Os quadrinhos surgem na virada do século XIX para o XX em um contexto de crise da cultura, isto é, em um momento em que transformações sociais e inovações técnicas desdobravam-se no âmbito da cultura. Walter Benjamin parte da metáfora marxista da dinâmica entre base e superestrutura em seu seminal artigo para uma teoria marxista da cultura $A$ obra de arte na era de sua reprodutibilidade técnica. Segundo ele, Marx não podia analisar mais detalhadamente as formações culturais no capitalismo por que essa esfera superestrutural não havia ainda sido moldada de forma mais sólida em seu tempo, dado o descompasso que haveria, em sua hipótese, entre o desenvolvimento da economia e o desenvolvimento da cultura, essa ulterior porque condicionada pela primeira. No século XX, porém, as formações da cultura sobre as bases econômicas do capitalismo consolidado já era muito mais perceptível em sua diversidade de expressões. A intenção de Benjamin era dar prosseguimento ao trabalho de Marx justamente nesse dado que a história ainda não havia oferecido para o pensador oitocentista, sobre os quais pode apenas emitir prognósticos com base nas tendências do desenvolvimento histórico que havia identificado.

Para a formação dos quadrinhos contribuíram diversos fatores ligados essencialmente ao surgimento de um sujeito histórico identificado com as assim chamadas massas, imersos em um contexto de relativa democratização do sistema político e à expansão da alfabetização observada, sobretudo, juntamente às populações urbanas. Sob essas novas condições surge uma imprensa de ampla circulação, inicialmente com os jornais. Notamos que, além de sua relação com as artes visuais, os quadrinhos mantém uma relação próxima com o meio jornalístico em que se firmou. É internamente a seu veículo e sua estrutura convencional que surgem as formas embrionárias dos quadrinhos, as charges, cartuns e tiras de temática cômica, destinadas a fazerem contraponto ao austero formato do corpo principal dos jornais. Muitas vezes contemplando fatos noticiados, podem possuir um tratamento enviesado com relação à sua contraparte: humorístico, irônico, sarcástico, caricato, etc. Nesse tratamento quase sempre prevaleceu, em maior ou menor grau, a verve crítica. Tal papel foi antes desempenhado pela 
chamada imprensa ilustrada, que no século XIX já era alternativa à dita grande imprensa, consistindo de fato em um viés na forma opinativa quanto à crítica da política e dos costumes realizada especialmente por meio das já referidas charges, cartuns e tiras cômicas.

A integração dos quadrinhos à grande imprensa foi justamente o impulso inicial para sua ampla recepção, que mais tarde viria a ser cada vez mais segmentada e complexa. Foi nos jornais que surgiu um produto cultural destinado ao consumo infanto-juvenil que contribuiu significativamente para alçar progressivamente os sujeitos sociais dessa faixa etária à condição de consumidores relativamente independentes. Trata-se dos suplementos impressos que continham histórias em quadrinhos produzidas para as crianças e jovens em geral. Para além do jornal, surgiria mais tarde a revista infanto-juvenil de histórias em quadrinhos e ainda mais tarde os livros de quadrinhos que voltariam a dirigir a linguagem dos quadrinhos também para o público adulto. É justamente através do exemplo do jornal, specialmente da imprensa ilustrada, que Walter Benjamin (1995), em seu artigo O autor como produtor, defende o hibridismo técnico nas artes onde passam a coexistir em um único veículo uma variedade de formas de representação da realidade destinadas a serem consumidas pelas massas.

Benjamin também é o autor que nos oferece melhores subsídios para pensar os quadrinhos em sua relação com o desenvolvimento das inovações materiais que atingiram as artes em seu artigo já referido sobre a reprodutibilidade técnica. No que diz respeito à narrativa através das imagens, é irreversível o processo desencadeado pelo surgimento da câmera fotográfica e cinematográfica. O novo modo de percepção visual propiciado pela câmera difere fundamentalmente do olhar nu e por isso a produção de imagens nos quadrinhos é mediada tanto pela experiência visual da fotografia e do cinema quanto pela observação direta da realidade visível. A escolha de planos e enquadramentos nos desenhos dos quadrinhos recorre muito mais à memória visual educada pela tela do cinema ou da televisão que à observação direta. No caso do jornal, o ladeamento das informações visuais e verbais implicou também, por exemplo, certa obsolescência da descrição literária da aparência física de objetos retratados por meio do desenho ou da fotografia. Essa inovação técnica é de particular importância para a compreensão dos quadrinhos em sua característica de síntese visual-verbal.

Para além das similitudes e discrepâncias formais e técnicas entre literatura, pintura, cinema e os quadrinhos, talvez o fato mais relevante nessa relação entre linguagens deve 
residir no próprio desenvolvimento material dessas formas artísticas, ou meios de comunicação; ou seja, no próprio consumo, recepção, produção e reprodução dos mesmos. Embora em seu desenvolvimento histórico a literatura e a pintura sejam formas consagradas pelo passado sobre as quais desenvolveram-se as histórias em quadrinhos, por outro lado seu desenvolvimento se dá em simultaneidade com o cinema, sendo a relação entre os dois últimos muito mais intensa e direta.

No mesmo autor podemos vislumbrar uma diferenciação entre a imagem da pintura e da fotografia daquela dos quadrinhos que podem apontar para sua maior especificidade. Tratase da diferenciação que este faz entre a imagem pictórica, que estaria ligada à esfera da representação, da imagem gráfica, ligada à esfera da significação. Enquanto a pintura e a fotografia representam a realidade visível o desenho gráfico (característico das histórias em quadrinhos, que em sua imensa maioria privilegiam a linha) codifica os objetos reais na forma de signos. Acreditamos que no caso dos quadrinhos atuam as duas formas perceptivas (Paint and the Graphic Arts; On Painting, or Sign and Mark. In.: BENJAMIN, 2008).

No centro de todo o debate sobre a crise cultural está a questão de seus efeitos políticos. Benjamin, ainda no artigo sobre a obra de arte, sentencia que o estudo das artes deve estar orientado pela política da arte [Kunstpolitik]. A funcionalização revolucionária das artes tem padecido de críticas de panfletarismo, dirigismo político sobre a criatividade etc. Escrito sob o sombrio período de ascensão do nazi-fascismo, a inserção desse texto é de contraposição a essa defendendo a politização da arte contra a estetização da política, essa última amplamente desenvolvida pela poderosa máquina de propaganda fascista. Assim contextualizado, a releitura desse texto com essa ênfase pode parecer descabida e anacrônica. Afinal, o nazismo perdeu a grande guerra e hoje a democracia reina no ocidente. A realidade é assim definida apenas em seu desenho mais superficial. O nazismo gerou frutos. A publicidade e a propaganda que media nossas relações de troca mercantis deve muito de seu know-how a Goebbels. Nossos regimes democráticos ocidentais ainda praticam o terror de Estado para reprimir manifestações e movimentos sociais com suas reivindicações muito mais democráticas que as formas estatais que usurpam seu nome. Enfim, ainda vivemos em uma sociedade capitalista e a proletarização da humanidade continua avançando.

Benjamin deu especial atenção ao cinema (mas não apenas a essa forma) nascente no início do século XX e nele viu potencialidades de usos revolucionários. Benjamin já havia se referido explicitamente à antinomia entre forma e conteúdo como integrante de uma 
problemática estéril ( $O$ autor como produtor, In.: BENJAMIN, 1995) e preferiu o conceito mais palpável de "técnica" por se associar com o conceito mais geral do "meio de produção cultural". A forma dos quadrinhos - e "forma" entende-se aqui como um princípio conformador (...) no sentido mais amplo" (WILLIAMS, 2007, p. 188) - como um gênero artístico marcado historicamente, é determinada materialmente por uma série de desenvolvimentos técnicos e experiências sociais e individuais e é, tal qual a conhecemos hoje, um fenômeno cultural do capitalismo avançado. Como coloca Benjamin em A obra de arte na era de sua reprodutibilidade técnica, o próprio fato tecnológico da reprodução técnica das imagens em larga escala (além do novo meio de produção de imagens, a fotografia) alterou profundamente a natureza das artes, que agora são em sua imensa maioria produzidas para as massas. Assim sendo, sua função política é inevitavelmente ampliada.

Ao passarem a ser vistas como comunicação, as artes são enfatizadas enquanto mediação. No paradigma direcional funcionalista da comunicologia (muitas vezes redutor do ponto de vista teórico), pressuposto no modelo midiático de comunicação, em que o objeto é um veículo mediador que transmite idéias, mensagens, conteúdos, etc. nos serve para identificar uma etapa do processo: no caso, a produção quadrinística. Preferimos, todavia, não fiar-nos nessa vertente, mas sim em uma concepção dialética da relação unitária entre mediação e comunicação, melhor resumida na sentença de Adorno: "a mediação está na própria coisa, não sendo algo que seja acrescido entre a coisa e aquelas às quais ela é aproximada. Só este último elemento é que é, porém, entendido como comunicação" (ADORNO, 1986, p. 114).

Como observou Raymond Williams (2007, p. 275), essa concepção de “mediação" se relaciona com a teoria formalista na medida em que também suplanta questões das relações entre "produtores" e "consumidores" da cultura, nas quais a mediação quase sempre surge como etapa negativa, seja como ideologia ou ruído. Nos estudos comunicacionais sobre quadrinhos tal distinção é notada inclusive por distinções de enquadramento ou de foco da pesquisa. Estudos sobre "linguagem" ou "técnica" dos quadrinhos dissecavam o objeto para identificar sua especificidade formal, para descobrir o quê, afinal, conforma uma história em quadrinhos. Em outro momento, a "análise de conteúdo" desentranhava-o para descobrir seus possíveis significados políticos e funções sociais. É a visão de comunicação enquanto conformação social do receptor, essa quase sempre ideológica, por vezes pedagógica - enfim, sua função "negativa" ou "positiva" depende do partido político do estudo. 
Um dos maiores clássicos da bibliografia teórica específica sobre os quadrinhos nas ciências da comunicação é o livro redigido conjuntamente por Dorffman e Mattelart, Para ler o Pato Donald (1978). Para além da esmagadora influência althusseriana sobre o marxismo ocidental desses anos à qual nossos autores não escaparam, devemos levar em conta o contexto mais localizado em que foi escrito: o projeto socialista chileno recém posto em marcha através da eleição democrática de Salvador Allende. Nesse contexto o impacto arrasador do imperialismo norte-americano tornou-se patente e esse fato possui muito mais influencia no livro chileno que sua linha teórica de matriz francesa. Muitos dos que ainda hoje consideram exagerado o aberto anti-americanismo desse livro parecem esquecer-se do trágico dado histórico chileno da primeira metade da década de setenta (e lembre-se de passagem que quando de sua escrita o Plano Condor ainda era uma conspiração secreta). A partir da identificação da ideologia imperialista estadounidense em um de seus produtos culturais mais emblemáticos - os quadrinhos Disney - esses dois chilenos procedem em uma análise crítica da produção quadrinística cujo efeito político pressuposto é a aculturação ideológica. Não procedem em uma análise da recepção ou outras metodologias de pesquisa que pudessem relativizar a determinação ideológica desses produtos. Os sujeitos receptores (talvez por se tratarem primordialmente de crianças) parecem ser considerados de antemão tábula-rasa para a absorção passiva da ideologia colonialista.

Se a recepção subjetiva da ideologia não foi objeto daquele estudo, também a subjetividade de sua produção não o foi, sendo que sua análise crítica e estrutural da ideologia disneyana torna-se o meio por excelência para a resistência e superação da mesma. Uma análise crítica mais próxima e propositiva para com a produção artística, inviabilizada e mesmo desprovida de sentido naquele contexto de guerra-fria e do mais acirrado imperialismo norte-americano na América Latina, poderia ser um caminho melhor para a superação da ideologização capitalista nos quadrinhos.

Uma abordagem mais interessante do ponto de vista do papel do sujeito na produção quadrinística dos quadrinhos Disney foi empreendida por Eloar Guazzelli (2009), que analisa o caso do quadrinista Canini, um dos maiores desenhistas do personagem brasileiro daquela empresa, o Zé Carioca. Ele nos mostra que Canini empreendeu uma resistência aos ditames fordistas da Disney em dois sentidos. O primeiro deles se refere ao conteúdo social de suas historinhas, que se aproximavam muito mais da realidade cultural brasileira do que a matriz norte-americana gostaria; o segundo se refere à questão do sistema de produção, no qual 
Canini buscava formas veladas de deixar a marca de sua autoria individual, algo negado aos desenhistas empregados por aquela companhia, que deviam se resignar como simples tarefeiros apócrifos e no caso de possuírem talentos destacados acabavam por enriquecer o capital simbólico da grife Walt Disney. Canini foi o resistente da autoria artística e da identidade nacionalista no Brasil. Nos Estados Unidos alguns de seus autores subordinados viriam ao conhecimento do público com o mesmo atraso: Carl Barks foi reconhecido $a$ posteriori pelo público como o melhor autor de suas revistas; Walt Kelly saiu de sua custódia empregatícia para realizar a série de quadrinhos, Pogo, de conteúdo social, digamos, mais progressista.

Por meio dos exemplos desses dois estudos queremos enfatizar a importância da análise dialética sobre os quadrinhos. Por um lado, a identificação estrutural da ideologia se torna pobre se não dermos atenção para os sujeitos que pensam por meio dela. Por outro, uma historiografia voluntarista dos quadrinhos onde a autoria e sua influência adquirem plena autonomia frente às determinações econômicas, técnicas, etc. também não é adequada. As tensões entre condição e ação, necessidade e liberdade, matéria e idéia são de uma real e complexa tessitura e não podem ser deduzidas por analogias simplistas que identificam conceitos e categorias entre si relacionados apenas no plano ideal. A dicotomia mecânica entre base e superestrutura, por exemplo, perdeu muito de sua importância no marxismo pósestruturalista por ter contribuído demais para tais confusões logicistas.

Se nosso ponto de partida fosse a defesa incondicional do meio dos quadrinhos, nos inclinaríamos obviamente para o partido benjaminiano. Porém, a questão é mais complexa e não se trata de tomar partido de uma forma ou um meio específico. Bertolt Brecht, nesse debate de eleição de formas para fins revolucionários acusa Lukács de ser um "formalista" involuntário. Ele parte de um ponto de vista não apenas teórico como de sua experiência prática, ou seja, de sua práxis artística. Aí ele irá enfatizar que não basta defender as potencialidades técnicas abertas pelo desenvolvimento capitalista (defesa contida em Benjamin, nos dois sentidos); há que se valer das mesmas visando a transformação social. Os exemplos da estética brechtiana são muito emblemáticos nesse sentido, pois o autor dedicou sua vida à revolução social lançando mão de seu Teatro Épico e Didático em um relacionamento imbricado entre história e arte, em suas teorias e práticas.

Para Lukács, é a estrutura da divisão social do trabalho, no caso das artes através do processo de sua mercantilização e conseqüente profissionalização especializada, determinante 
para a alienação técnica da experiência do artista. Dessa forma também é alienada sua visão de mundo [Weltanschauung], cada vez mais parcelar e fragmentada. Sob essas condições a função reflexiva do sujeito artístico se vê comprometida e da mesma forma o reflexo da realidade que sua obra deveria produzir. Tudo isso contribui para o processo que o autor define sem rodeios como decadência das formas literárias e artísticas em geral, contra as quais segue defendendo a idéia de uma "grande arte" contraposta aos produtos culturais massificados. Postura semelhante é a de Adorno e Horkheimer, que vêem no processo de massificação cultural uma tendência à padronização, o que nivelaria "por baixo" a qualidade dos seus produtos. Tais críticas possuem um caráter relativamente sectarista e, talvez, elitista até. Não podemos, contudo, confundir questões culturais posteriores a esse debate, como é o caso da distinção entre cultura de massas e cultura popular.

As transformações artísticas trariam também consigo mudanças nas formas de percepção da realidade. No debate aqui resgatado, Lukács, Adorno e Horkheimer foram sobremaneira pessimistas em criticar as novas formas artísticas como sendo precursoras de uma decadência nas formas de pensamento. Benjamin, diferentemente destes autores, lançou sobre esse cenário um olhar mais promissor. Tal autor observa essa crise, mas ao invés de se posicionar de forma conservadora, busca saídas para o impasse. Em seus apontamentos para uma Teoria da Distração, identificada com o fator de entretenimento dos novos produtos culturais mas estendida para uma nova mentalidade implicada por estes. Segundo Jean-Marie Gagnebin (2008, p. 109) em comentário a essa teoria:

O ensaio sobre $A$ obra de arte na era de sua reprodutibilidade técnica, notadamente, pode ser lido não só como a descrição do fim de uma idade estética, mas também como a tentativa de uma estética positiva da distração [Zerstreuung], portanto, de outro tipo de percepção [Aesthêsis] que o do recolhimento cultual e cultural, uma percepção ao mesmo tempo difusa e perspicaz (...)

Essa teoria, se interpretada como resposta à crítica decadentista, abre a possibilidade para observarmos as histórias em quadrinhos, enquanto forma artística preferencialmente voltada ao entretenimento e, portanto, a distração, como uma leitura diferenciada que traria, com relação ao exemplo da literatura, uma nova percepção da realidade. Percepção essa não necessariamente pior ou melhor. Ainda cabe aqui observar que, na ampla variedade de produtos quadrinísticos, alguns pendem em maior ou menor medida para os lados opostos da 
leitura distraída ou concentrada. Uma tira cômica pode ser lida em poucos segundos e sem maiores pretensões cognitivas. Já um romance gráfico que busque comunicar o conhecimento histórico pode exigir muito mais concentração e ser lido, digamos, de forma menos corriqueira e mais ritualística.

Devemos observar ainda, além de uma coexistência das práticas concentrada e distraída na leitura dos quadrinhos, aquilo que essa forma trouxe de novo no âmbito da fruição estética. Seja essa fruição atenta ou dispersa, "séria" ou "divertida", implica novos procedimentos perceptivos e cognitivos. Os quadrinhos são comumente lembrados como uma forma textual bastante intuitiva. Sua leitura, contudo, não é um exercício naturalmente dado e acabado, mas socialmente formado. Por isso especialistas na linguagem específica dos quadrinhos enfatizam a necessidade de uma alfabetização quadrinística (VERGUEIRO, 2004; RAMOS, 2009). A formação de uma leitura mais atenta também traria consigo uma apreensão mais perspicaz de seus procedimentos simbólicos e representacionais - esse último processo especialmente caro à didática da história.

Benjamin, no mesmo registro dos apontamentos para uma Teoria da Distração, ainda afirma a possibilidade de liberdade de escolha para o produtor artístico, mantendo assim seu papel de sujeito histórico: "no que concerne ao valor educacional [Lehrwert], 'o autor como produtor' despreza o valor comercial [Konsumwert]." (Theory of Distraction, In: BENJAMIN, 2008, p. 56, tradução nossa). Tal apontamento faz referências cruzadas a dois outros textos de sua autoria citados anteriormente. O primeiro deles é $A$ obra de arte na era de sua reprodutibilidade técnica; o segundo é $O$ autor como produtor. É também uma proposta que concilia entretenimento e educação, onde o "valor educacional e o valor de consumo convergem, tornando assim possível um novo tipo de aprendizado" (BENJAMIN, idem, p. 57, tradução nossa).

No cenário quadrinístico, tal intuição já havia sido expressa pelo já citado Will Eisner: "Sem dúvida, a preocupação pedagógica séria ofereceria um clima melhor para a produção de conteúdo temático mais digno e para a expansão do gênero como um todo" (EISNER, 2001). Aqui gostaríamos de fechar o debate apontando para a convergência da questão da funcionalização política das artes e das funções da cultura histórica em sua comunicação. Não é objetivo de nosso estudo observar diretamente tais implicações, mas gostaríamos de deixar claro que o conhecimento e a cultura histórica não são politicamente neutras. Nesse caso, a consciência de sua função política por parte dos sujeitos históricos que 
situam-se em lugares privilegiados da comunicação, no nosso caso quadrinistas e historiadores, é imprescindível para não incorrerem desavisadamente na reprodução da ideologia capitalista.

A História é escrita no presente e não foge às suas contingências, tampouco às ideológicas. São os problemas do presente que devem orientar a investigação histórica. A acedia historicista e cientificista crê que acumulando conhecimentos factuais mantém sua neutralidade ou, no mínimo, contribui para uma espécie de progresso intelectual da humanidade. Walter Benjamin, em seu ensaio Sobre o conceito de História (BENJAMIN, 1995), precaveu-nos contra à esterilidade desse entendimento da história e de suas implicações sociais apáticas e conformistas. O conhecimento histórico produz seus efeitos na sociedade, esteja ele contido em teses científicas ou em histórias em quadrinhos. Pode ser no sentido da reprodução das condições existentes, seja consciente ou inconscientemente, através da omissão frente às forças dominantes na sociedade e da legitimação dessa dominação, ou da resistência a ela; da tentativa, essa invariavelmente consciente, de romper um ciclo, revolucionando-o. Trata-se de buscar uma forma de narrativa histórica que realmente faça diferença na vida de quem a lê. Não apenas que esse leitor conheça belas narrativas e, através delas, acumule conhecimento, mas que ele se identifique com essas narrativas e, através desse conhecimento, se reconheça como parte do processo histórico para nele melhor pensar e agir.

A possibilidade da comunicação do conhecimento histórico e consequente formação de uma consciência histórica criticamente orientada por meio dos quadrinhos é um dado real proporcionado pelos desenvolvimentos culturais engendrados pelo próprio capitalismo. Observar sua função social inerente parte do ponto de vista totalizante da sociedade, nos quais as artes e as ciências não constituem-se em fenômenos isolados, muito embora assim pareçam ser praticadas na maioria dos casos. Buscar tal reintegração se refere à própria percepção e conhecimento crítico da realidade histórica. 


\section{COMUNICAÇÃO ESTÉTICA DO CONHECIMENTO HISTÓRICO}

"Será que é possível estabelecer se são mais numerosos os homens que aprenderam a história de sua pátria através da arte do que através da ciência?"

György Lukács

Do ponto de vista disciplinar da história a inserção de nossa pesquisa é mais delicada e exige certas distinções. Não se trata de um estudo historiográfico propriamente dito, mas de um estudo didático-histórico. Aqui entendemos a didática da história como um ramo da teoria da história que analisa com seus próprios instrumentos a cultura histórica socialmente mais ampla e sua relação com o conhecimento histórico produzidos segundo o método científico. Nesse sentido, o instrumental teórico-metodológico da ciência histórica constitui nossa pedrade-toque para avaliar criticamente os resultados dessa produção de quadrinhos históricos, suas limitações e possibilidades em formatarem o conhecimento histórico, isto é, em dar forma quadrinística para o saber histórico. Nosso foco principal não é, portanto, escrever uma história desses quadrinhos, mas mais exatamente observar que história esses quadrinhos escrevem - e desenham, claro. Em outras palavras, não nos interessa tanto a historização dos quadrinhos quanto a quadrinização da história.

A didática da história [Geschichtsdidaktik] a qual evocamos provém de desenvolvimentos recentes da tradição alemã da teoria da história, tendo como seu principal representante Jörn Rüsen. A palavra "didática" nesse contexto, não se refere nem à arte de ensinar [Lehrkunst] ou mesmo a uma coleção de métodos educacionais aplicáveis em qualquer área do conhecimento [Unterrichtsmethoden] (CARDOSO, 2008); também não se referem a um artifício formal de ordem comunicacional para transmissão de conteúdos dados, mas à própria comunicação produtiva da cultura onde forma e conteúdo são inextrincáveis. Os objetos desta teorização são as formas e funções da cultura e do conhecimento histórico. No caso do nosso estudo, focamos a primeira instância. 
Formas e funções, entretanto, andam juntas. Na análise da produção de quadrinhos em didática da história, os escritores aventuram-se no conhecimento histórico lidando com esse objeto delicado, que demanda uma investigação especial, um estudo mais cuidadoso. Como os situa Guazzelli:

\footnotetext{
Estes escritores de quadrinhos são seres sociais, permeáveis a múltiplos condicionamentos e determinações, e suas histórias não são neutras. Idealização ou denúncia, descrição linear ou análise crítica, são posturas que os autores revelam na investigação de suas obras (GUAZZELLI, 2000).
}

Tal colocação pode ser desdobrada em dois sentidos: o primeiro deles se refere a postura política dos quadrinistas que comunicam saberes históricos, estando relacionados com uma funcionalização consciente da história. O segundo desdobramento se refere à questão da investigação, esta relacionada à cientificidade do conhecimento histórico. Aí que se faz imprescindível a aproximação da arte com os métodos científicos do conhecimento histórico. As expressões artísticas não científicas, por estarem aquém ou próximas do marco disciplinar da ciência histórica, também podem ser chamadas de "obras fronteiriças" (ALBIERI; GLEZER, 2009).

Trata-se de uma das relações mais delicadas do processo em questão por se trazerem à discussão questões éticas caras à epistemologia, principalmente no que concerne à tensão entre objetividade e subjetividade no fazer do conhecimento histórico, que, grosso modo, pode ser identificada em sua forma mais simples com a tensão entre a factualidade histórica e a imaginação poética. Trata-se da distinção aristotélica entre história - relato do que foi - e poesia - relato do que pode, poderia ou poderá ser. Desdobremos a questão da narrativa histórica contraposta à narrativa de caráter ficcional, tais como a literária e a quadrinística. Tomemos para tanto outra reflexão de Guazzelli:

As histórias [em quadrinhos] apresentam algum grau de fantasia e aventura mesclado à reconstrução do passado, o que não difere fundamentalmente dos "romances históricos", como Ivanhoé de Scott, Os três mosqueteiro, de Dumas ou Lendas e Narrativas de Herculano. A discussão não seria sobre a validade dos quadrinhos como forma de divulgar a História para as massas, mas das obras de ficção de uma forma em geral. Um pouco diferentes seriam as "quadrinizações" da História, quando obras ou fatos conhecidos são adaptados para a linguagem da História em Quadrinhos. (GUAZZELLI, 2000) 
$\mathrm{Na}$ tensão entre factualidade e ficcionalidade reside um dos maiores problemas da representação artística da história. A seguir, veremos como foi refletida a questão no âmbito de duas outras formas de representação artística da cultura histórica, o romance histórico e a pintura histórica. 


\subsection{De outras formas de comunicação estética da história}

Neste sub-capítulo debruçamo-nos sobre reflexões acerca de duas formas artísticas que envolvem a representação histórica. Trata-se do romance histórico, cuja análise mais profunda foi desenvolvida pelo pensador György Lukács; e da pintura histórica, sobre a qual apropriamo-nos da análise empreendida pelo historiador Peter Burke. A utilidade destas reflexões se notará quando da análise empírica dos quadrinhos didático-históricos, já que os mesmos se relacionam com as formas do romance e da pintura histórica que lhes antecederam. Também partimos do uso do adjetivo "histórico" que designam tais gêneros para legitimar sua extensão à identificação de um possível gênero quadrinístico, o quadrinho histórico. 


\subsubsection{Lukács e o romance histórico}

Ainda sob a herança eminentemente hegeliana, György Lukács havia escrito a Teoria do Romance, em que desenvolvia as questões da forma do gênero literário do romance nos termos de sua tradição. Após um longo processo de desenvolvimento do seu pensamento rumo ao marxismo e de sua integração ao processo histórico pós-revolucionário da União Soviética ele viria a escrever, em fins da Segunda Guerra, o Romance Histórico, no qual os problemas da forma deste subgênero do romance passam não apenas a ser mais profundamente relacionados com processos históricos concretos e específicos em sua explicação histórica, mas a própria discussão contemporânea dos usos dessa forma estão politicamente orientados para uma práxis cultural pós-revolucionária. Para Lukács, o renascimento de um romance histórico verdadeiramente histórico é um imperativo cultural nesse contexto. Para melhor entendermos esse ponto, é preciso retroceder um pouco em sua obra.

No início da Segunda Guerra, em 1939, Lukács havia escrito um texto seminal para a questão da práxis no âmbito da literatura, Narrar e Descrever (LUKÀCS, 2010). Nesse texto o autor expõe, a propósito dos movimentos literários realistas do século XIX, uma diferença crucial na postura dos escritores perante a vida e a história, ou seja, em sua práxis. Trata-se da participação ativa na vida social por um lado e da abstêmia observação da mesma por outro. Tais posturas refletiriam artisticamente em uma prosa narrativa no primeiro caso, que confere um caráter de sujeito ativo para seus personagens através da narração de seus feitos; e no segundo caso de uma prosa descritiva, em que os personagens tornam-se objeto passivo de uma história desumanizada, em que prevalecem a descrição objetiva desse mundo fatalmente dado. Tais expressões literárias situam-se nas tendências do romance histórico ou épico da primeira metade do século XIX e o romance naturalista da segunda metade, respectivamente.

É interessante notar que tais posturas não coincidem necessariamente com a tomada por este ou aquele partido nas lutas de classes do período, sendo acentuadamente uma orientação para a participação nas mais amplas esferas da vida pública em detrimento de uma prática literária profissional especializada. Lukács cita como exemplos da primeira tendência Balzac, que era simpatizante de aristocracia decadente, porém circulava nos mais diversos 
círculos sociais; e Tolstoi, que não se deteve em tomar parte inclusive em um processo de recenseamento da população russa. Na segunda metade, cita Zola como um exemplo do objetivismo descritivo historicamente amorfo apesar de este assumir e ser considerado legítimo representante da causa proletária na literatura. Tais aparentes contradições se resolvem na defesa do realismo de Lukács, que estaria ligado à uma compreensão profunda e totalizante da sociedade, de sua essência e de suas tendências, e um comprometimento ético com a verdade histórica contida nessa compreensão dialética. Daí resultaria que mesmo sendo Balzac um defensor dos valores aristocráticos, sua produção literária não trairia sua compreensão dialética do processo histórico de decadência da aristocracia européia. Já Zola incorria, para Lukács, em uma apresentação dos fenômenos superficiais do processo histórico.

Em O Romance Histórico Lukács desenvolve mais amplamente sua tese do realismo como forma de reflexo dialético da realidade histórica. À identificação da "forma clássica" de romance histórico na primeira metade do século XIX e à percepção de seu declínio segue-se a defesa de seu retorno no contexto da cultura soviética pós-revolucionária. Manifestações posteriores do realismo seriam para o autor inversões de perspectiva, não necessariamente idealistas, mas muitas vezes uma corruptela do materialismo.

O que quer dizer afinal a palavra "histórico" no conceito lukácsiano de romance histórico? Que limites o definem e para que se presta? Na análise concreta das primeiras obras de prosa literária que se dedicam ao tratamento da história identificam-se logo de início aquelas que possuem apenas uma pseudo-historicidade:

The so-called historical novels of the seventeenth century are historical only as regards their purely external choice of theme and costume. Not only the psychology of the characters, but the manners depicted are entirely those of the author's own day. (...) history is likewise treated as mere costumery: it is only the curiosities and oddities of the milieu that matter, not an artistically faithful image of a concrete historical epoch. [grifo nosso] (LUKACS, 1983, pg. 19)

Já temos uma definição lukácsiana genérica, acentuada pela passagem grifada, de uma obra de arte verdadeiramente histórica. Tal definição já descarta qualquer tratamento da história como mera curiosidade, tratamento ao qual Walter Benjamin se referiu como uma história de antiquário, um colecionismo despolitizado dos objetos históricos. Tal tratamento é muito corrente na disciplina histórica escolar pautada pela organização curricular dos 
conteúdos históricos. Mesmo o mais erudito conhecimento dos fatos históricos definitivamente não conduz por si só ao entendimento do processo histórico em sua dinâmica. Seguindo na mesma passagem:

What is lacking in the so-called historical novel before Sir Walter Scott [marco inicial do romance histórico segundo Lukács] is precisely the specifically historical, that is, derivation of the individuality of the characters from the historical peculiarity of their age. (...) that characters should be socially and psychologically true, demanding that a ruler make love differently from a shepherd, and so on. The question of historical truth in the artistic reflection of reality still lies beyond this horizon. [g.n.] (LUKÀCS, 1983, pg. 19)

As implicações dessa forma de perceber a história vão muito além da ignorância histórica, pois se relaciona com uma visão de história estática, calcada na idéia de uma natureza humana inalterável. É uma percepção fundamentalmente ahistórica e antidialética. Segundo Lukács, a precondição histórica material para o surgimento do romance histórico foi a Revolução Francesa e seus desdobramentos:

\begin{abstract}
It was the French Revolution, the revolutionary wars and the rise and fall of Napoleon, which for the first time made history a mass experience, and moreover on a European scale. During the decades between 1789 and 1814 each nation of Europe underwent more upheavals than they had previously experienced in centuries. And the quick succession of this upheavals gives them a qualitatively distinct character, it makes their historical character far more visible than would be the case in isolated, individual instances: the masses no longer have the impression of a "natural occurrence". (...) Now if experiences such as these are linked with the knowledge that similar upheavals are taking place all over the world, this must enormously strengthen the feeling that there is such a thing as history, that it is an uninterrupted process of changes and finally that it has a direct effect upon the life of every individual.
\end{abstract}

Essa última reflexão diz respeito ao que pode ser chamado, segundo a teoria didático-histórica que utilizamos, de consciência histórica, isto é, a consciência dos sujeitos pensantes de sua própria historicidade (RÜSEN, 2007). Esse é um dos problemas centrais da referida obra de lukács, e por isso no seu conceito de romance histórico não é central o reporte ao conhecimento factual da história. No romance histórico a ficcionalidade, que é expressa principalmente por meio de personagens fictícios enredados em processos históricos, é uma intromissão bem-vinda. Através desses personagens o leitor perceberia de forma sensível, 
mais que cognitiva, a inserção histórica do ser humano. Daí que o romance histórico se liga mais à consciência histórica que ao conhecimento histórico, este último mais regrado pela factualidade. 


\subsubsection{Peter Burke e a pintura histórica.}

O historiador britânico Peter Burke, em suas reflexões sobre as relações possíveis entre história e imagem, aponta para uma possibilidade de certa forma negligenciada pelos historiadores. É a possibilidade de que os pintores históricos, particularmente a partir do final do século XVIII, possam sim ser considerados historiadores. Burke nos chama a atenção para o fato de que a reconstrução da história por meio de imagens tem um imenso poder sobre a compreensão histórica, pois ela nos "faz ver" a história por ser concreção de uma imaginação histórica que, nos melhores casos, é cientificamente informada. E, dada a complexidade da tarefa, desde a pesquisa do material histórico até sua representação, os pintores históricos mais sérios e bem sucedidos em seu intento seriam pintores-historiadores legítimos. $\mathrm{O}$ principal elemento que configuraria o papel de "historiador visual" para esses pintores seria sua preocupação recorrente com a representação fidedigna da cultura material, para a qual empreendiam minuciosas pesquisas antes de lançarem-se a "pintar o passado".

Peter Burke estabelece uma tipologia das pinturas históricas do final do século XVIII ao XIX que pode se adequar, por sua vez, às necessidades de classificação dos quadrinhos. Nessa tipologia, de certa forma, próxima aos modelos da literatura, ele tipifica seis "modos" de enxergar o passado que podemos, por nossa parte, relacionar às formas de representação do passado nos quadrinhos. São eles o épico (I), centrado em ideais de heroísmo e grandes feitos; o trágico (II), centrado em situações que envolvem maior dramaticidade; o realista (III), mais discreto que os dois primeiros; a história crítica (IV), a mais notável das formas de enxergar o passado; o anedótico (V), que geralmente caricatura a vida privada de figuras públicas; e, por último, a história como alegoria (VI), que representa o passado em alusão ao presente (BURKE, 2005). Essa tipologia poderia ser aplicada de formas similares à literatura e até à escrita histórica. É interessante notar nela, entretanto, sua relação com o elemento narrativo essencialmente imagético da pintura e por consequência dos quadrinhos, ou seja, das formas ou estilos de representação visual e de suas implicações sobre a interpretação do conteúdo dessa representação. 


\section{COMUNICAÇÃO QUADRINÍSTICA DO CONHECIMENTO HISTÓRICO}

A representação através dos quadrinhos de temas da história do Brasil e a adaptação quadrinística de obras canônicas da literatura brasileira não é algo novo na história do quadrinho brasileiro. Cresceu extraordinariamente, entretanto, na primeira década do século XXI, sendo um dos campos da produção de quadrinhos atualmente mais destacados na mídia impressa e virtual no país. A mesma tendência é verificável em maior ou menor medida também no cenário quadrinístico internacional. Um dos mais importantes estudos empreendidos sobre histórias em quadrinhos e sua relação com a narrativa histórica é intitulado Comic books as history, de Joseph Witek (WITEK, 1989). Nela o autor identifica duas fases na produção de quadrinhos didático-históricos nos Estados Unidos. Embora o autor use o conceito de didático em seu lato sensu para se referir apenas à primeira fase, representada especialmente pela coleção Classics Ilustrated, extendemo-los em seu stritu sensu para ambas as fases por ele identificadas. Na primeira, predominaria uma intencionalidade pedagógica mais marcada e uma visão da historiografia oficial e tradicional. A segunda surge de desenvolvimentos na história dos quadrinhos daquele país, especialmente o movimento de quadrinhos alternativos conhecido como underground ou comix, que teriam introduzido a idéia de realismo nos quadrinhos mais ou menos como era concebida nos debates literários. Seus principais responsáveis teriam sido Harvey Kurtzman, primeiro editor da revista $\mathrm{Mad}$; Robert Crumb, um dos precursores da autobiografia nos quadrinhos, juntamente com o roteirista Harvey Pekar; e, por fim, Art Spiegelman, que em seu resgate da memória do holocausto no quadrinho Maus, espécie de história oral mesclada com autobiografia, é lembrado como um dos mais importantes quadrinhos históricos já feitos.

Uma das primeiras experiências sistemáticas da produção de quadrinhos históricos no Brasil se dá na metade do século XX e tem como principal motivador o contexto conflituoso em que se encontravam envolvidas as histórias em quadrinhos em geral. É por volta desse período que os quadrinhos se vêm no centro de uma contestação por parte de alguns setores da sociedade, entre eles o setor da Educação, enquanto forma válida de leitura e expressão artística e, principalmente, quanto às temáticas mais correntemente associadas a tais obras, que já então eram erroneamente compreendidos como leitura exclusivamente infanto- 
juvenil. Como resposta a tais críticas algumas editoras que vendiam títulos de quadrinhos, em especial a Editora Brasil-América (EBAL), buscaram provar, através da apresentação de temas socialmente mais aceitos como "educativos" em si, temas "edificantes": é o caso dos temas históricos (bem como biografias de personagens ilustres ou temas bíblicos) e as adaptações de obras literárias (GONÇALO Jr., 2004). Tal experiência é um paralelo bastante próximo àquela empreendida nos Estados Unidos pala coleção Classics Illustrated, onde o contexto de perseguição aos quadrinhos era muito similar.

Acerca dessas obras foi realizado estudo por Alexandre Barbosa na ECA-USP, intitulada Histórias em Quadrinhos sobre a História do Brasil em 1950: a narrativa dos artistas da EBAL e outras editoras, defendida no ano de 2006. Seu objeto central, os quadrinhos históricos produzidos na década de 50, representam uma das mais sistemáticas experiências de quadrinhos com preocupação pedagógica e didático-histórica no Brasil, constituindo em uma coleção de corpo considerável. Após esse período, apenas experiências pontuais desse tipo tiveram lugar. Em um capítulo dedicado ao levantamento geral dos quadrinhos históricos brasileiros, Barbosa identifica nos anos oitenta uma revitalização do gênero - sendo esse, portanto, nosso marco cronológico. No fim do capítulo, sentencia que o mesmo gênero encontra-se desde então em certo "marasmo" (BARBOSA, 2006). Os três anos que se seguiram a essa dissertação, data em que as obras de quadrinhos passam a constar na lista do Programa Nacional Biblioteca na Escola (PNBE) do Ministério da Educação e Cultura (MEC) do Governo Federal brasileiro parecem apontar para o fim desse ostracismo, com muitos títulos sendo publicados em curto espaço de tempo. Se é difícil desvendar as origens dessa demanda cultural na sociedade brasileira, podemos ao menos afirmar que tal iniciativa governamental aqueceu significativamente o mercado editorial de quadrinhos no país, agora compondo uma fatia da maior parcela do mesmo que tradicionalmente é a de livros didáticos e educativos.

No caso do contexto atual brasileiro é muito tênue a ordem dos acontecimentos no que se refere ao crescimento dessa produção de quadrinhos que comunicam a cultura e o conhecimento histórico. Um dos fatos mais significativos nesse processo é a compra massiva de títulos, de histórias em quadrinhos entre outros, por parte do governo federal brasileiro desde 2006 destinados às bibliotecas escolares de todo o país através do PNBE. Tais títulos são selecionados por uma comissão universitária e tem privilegiado, além de clássicos "universais" do gênero quadrinístico (dentre os quais já estiveram inclusas mais de uma obra 
do referido Eisner), títulos que estejam sintonizados com os currículos escolares, entre eles quadrinhos históricos e as chamadas adaptações literárias (RAMOS, VERGUEIRO, 2009). Esse novo fato é, a nosso ver, o mais significativo no desenvolvimento recente do gênero do quadrinho histórico pois impulsionou consideravelmente a produção de quadrinhos didáticohistóricos. Nem todos esses quadrinhos, entretanto, se reportam ao conhecimento histórico cientificamente informado. No capítulo que se segue, demos atenção aquelas experiências recentes que, segundo o critério da relação com a instituição acadêmica, maior responsável pela produção de conhecimento científico, se relacionam mais evidentemente com o conhecimento histórico. 


\section{ESTUDOS DE CASOS DIDÁTICO-HISTÓRICOS}

Empreenderemos agora a análise propriamente dita de casos concretos em que se dá uma formatação quadrinística do conhecimento histórico cientificamente fundamentado. Elegemos, por isso, casos em que há uma relação mais evidente entre a produção quadrinística e do conhecimento histórico. Entre o principal elemento que unifica o nosso corpus podemos identificar o locus de sua produção científica, já que todos eles possuem uma relação direta com a pesquisa acadêmica.

Dividimos os casos em dois sub-capítulos. O primeiro deles contempla a experiência de André Toral, historiador e quadrinista que produziu uma história em quadrinhos que se relaciona intimamente com sua tese historiográfica. O segundo sub-capítulo contempla dois casos similares em suas formas e estilos quadrinísticos, mas que se distanciam em cerca de duas décadas no tempo. Sua produção, diferentemente do primeiro caso em que se trata de um autor apenas, se dá através da parceria autoral entre quadrinistas e pesquisadores acadêmicos. São eles os quadrinistas Angeli, Miguel Paiva e Spacca; e os historiadores Lilia Schwarcz e Júlio José Chiavenatto. 


\subsection{Adiós, Xamigo Brasileño: o quadrinho histórico de André Toral}

Experiência particularmente pertinente para o estudo das formas de comunicação quadrinística da história no Brasil é a de André Toral. Sua obra é caracterizada pelo interesse recorrente nos temas históricos ou, ao menos, por alguma forma de reflexão histórica, sociológica ou antropológica. O fato é mais compreensível se acrescentarmos que se trata de um autor formado no ensino superior de Ciências Sociais, Antropologia e História nos níveis respectivos de graduação, mestrado e doutorado. A produção quadrinística de Toral é, em sua especificidade, resultado orgânico da conjunção de sua formação artística e acadêmica.

Seu début no meio quadrinístico se deu em publicações hoje consagradas como marcos históricos do quadrinismo brasileiro voltado ao público adulto, tais como os títulos Animal, Circo, Chiclete com Banana e Lúcifer. Tais revistas, surgidas em meados dos anos oitenta, período de abertura política pós-ditatorial, são comumente lembradas pelo amplo uso da liberdade de expressão recém reconquistada pelo movimento democratizante da sociedade brasileira no que se refere ao seu conteúdo social, bem como por sua efervescência experimental da forma quadrinística. Constituíram-se também em poderosos veículos de exposição para os autores presentes em suas páginas, uma vez que eram o principal produto quadrinístico voltado para o público adulto disponível nas bancas de jornal. Não à toa, nesse cenário se consolidaram os grandes autores do quadrinho adulto brasileiro como Angeli, Laerte, Mutarelli, para citar apenas alguns dos mais eminentes desse rol.

Sua primeira narrativa, Pesadelos paraguaios, foi publicada na revista Animal em três partes nos anos de 1986, 1987 e 1988. Tratava de um tema que viria a ser recorrente em sua obra (e, logo veremos, é também o tema de sua obra-prima): a Guerra do Paraguai. Já sua primeira narrativa publicada independentemente como álbum, O Negócio do Sertão [figura 1], de 1992, republicada em coletânea recente, consiste em uma história de trinta e três páginas que trata do encontro entre grupos sociais de origem européia e povos nativos do território brasileiro - temática que será uma das mais recorrentes de seus quadrinhos. As demais histórias que publicou em revistas de quadrinhos eram caracterizadas por sua curta duração, em média aproximada de três páginas. Além de a quantidade de páginas ser 
adequada aos veículos em que as histórias eram publicadas, tal característica deve-se muito provavelmente às contingências da carreira acadêmica do autor, mantida simultaneamente à produção quadrinística. A disciplina da formação científica concede pouco tempo para atividades paralelas que exijam um planejamento minucioso e uma execução sistemática, como é o caso da produção de uma história em quadrinhos de maior fôlego.

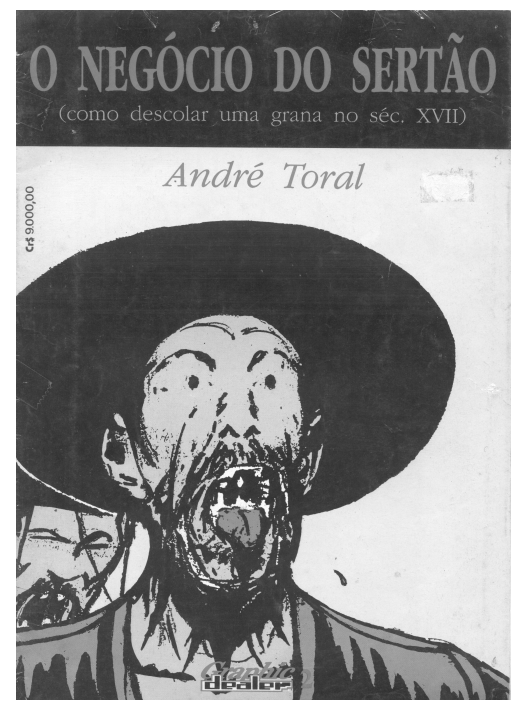

Fíg. 1: O Negócio do Sertão, 1991

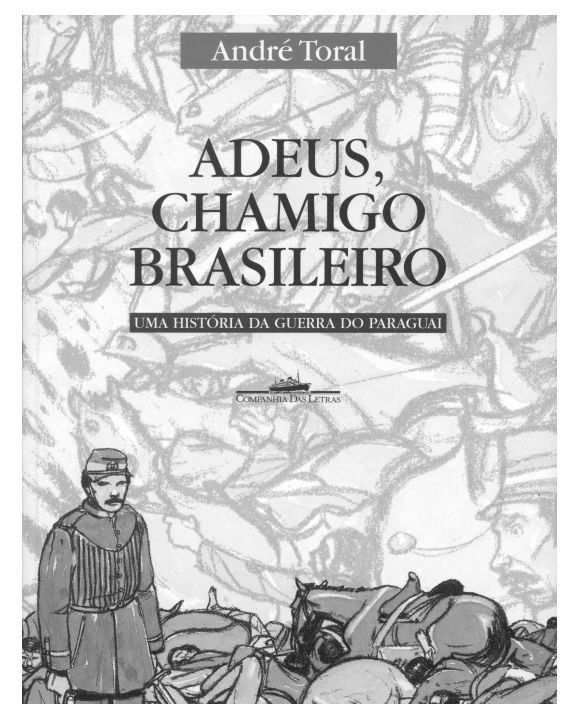

Fíg. 3: Adeus, Chamigo Brasileiro, 1999

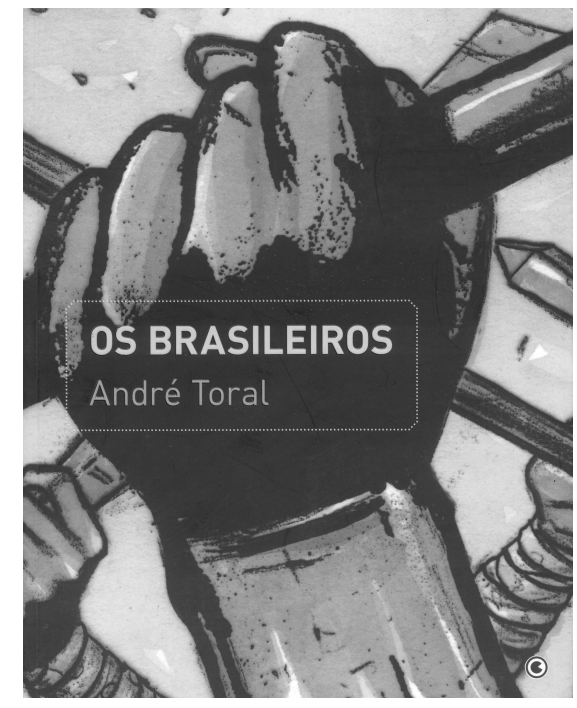

Fíg 2: Os Brasileiros, 2009

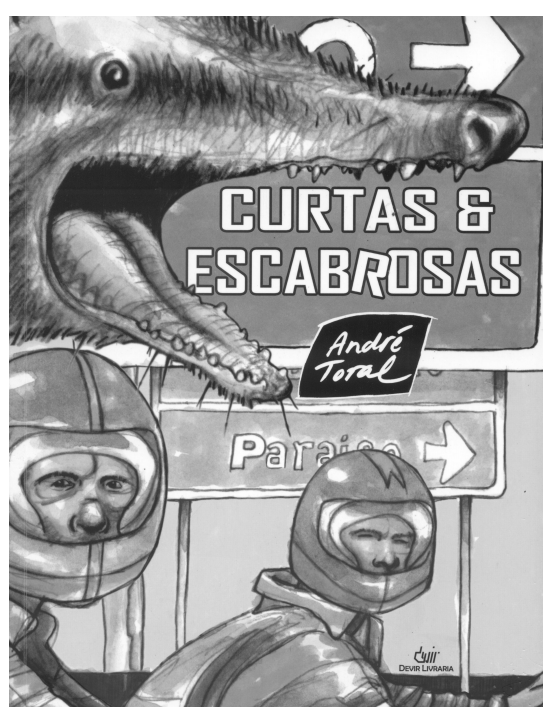

Fíg. 4: Curtas e Escabrosas, 2011 
Apesar disso - ou melhor, talvez por esse exato motivo - Toral produziu uma grande obra em quadrinhos conjuntamente à sua tese de doutoramento. Sua extensão pode ser medida em páginas (contam-se cento e dezesseis), mas seu maior mérito está em sua profundidade (essa mais difícil de medir) e que provavelmente vai além de tudo que já fora feito nos quadrinhos brasileiros. Referimo-nos aqui ao exaustivo trabalho de pesquisa histórica que antecede e fundamenta essa que é a sua maior e mais significativa narrativa: Adiós, Xamigo Brasileiro. Tal obra não se deu paralelamente e apesar de seu trabalho de doutorado então em curso, e sim como parte integrante e final do mesmo. A tese, realizada no Programa de Pósgraduação em História Social junto à Faculdade de Filosofia, Letras e Ciências Humanas da Universidade de São Paulo, é intitulada Adiós, Xamigo Brasileño: um estudo sobre a iconografia da guerra da Tríplice Aliança com o Paraguai (1864-1870) e foi defendida em 1997, sob a orientação do historiador Marcos Antônio da Silva. Ela se divide em duas partes, assim definidas pelo próprio autor: "a primeira é uma reconstituição histórica feita através da arte sequencial, a segunda, um levantamento comentado a respeito da iconografia da guerra" (TORAL, 1997, p. I, grifo nosso). Posteriormente, foram editadas como partes independentes sob os respectivos títulos: Adeus, Chamigo Brasileiro: uma História da Guerra do Paraguai (TORAL, 1999) [figura 3]; e Imagens em Desordem: a Iconografia da Guerra do Paraguai (1864-1870) (TORAL, 2001). As referências a sua obra serão feitas a partir da versão original da tese.

Adiós, Xamigo (...) é, portanto, relevante para a problematização da formatação quadrinística do conhecimento histórico cientificamente fundamentado. Trata-se de um exemplo representativo do quadrinho histórico, entendido como gênero quadrinístico que integra arte e ciência. Não nos interessa tanto discutir o estatuto de um e outro terreno mas sim estudar de que forma a obra em questão transita entre eles. Para tanto, analisamos nesse trabalho a obra em busca dos elementos que a aproximam dos fazeres historiográfico, e em um segundo momento analisamos os elementos propriamente quadrinísticos que constituem a especificidade dessa forma de reconstituição e narrativa histórica. 


\subsubsection{O quadrinho histórico como forma científica de arte ou forma artística de} ciência

O quadrinista Fábio Zimbres assim problematizou a produção de Toral:

O que é verdade e mentira na vida de André Toral? Seria ele um antropólogo vasculhando o bas fond brasileiro ou um espírito animado por obsessões inconfessáveis que se veste de cientista para colocar uma distância entre autor e obra? Por cortesia eu acredito na primeira hipótese mas a leitura das histórias dele nunca invalida a segunda. (In: TORAL, 2011)

A dicotomia entre ciência e arte costuma trazer "a reboque" outras dicotomias que se relacionam confusamente: verdade versus mentira; fato versus ficção; objetivo versus subjetivo. A relação entre arte e ciência na obra de Toral não é contraditória, mas dialógica, isto é, não se tratam de instâncias excludentes entre si, mas de instâncias que se complementam. A brincadeira de Zimbres - além de ironizar o próprio espaço em que se insere, uma orelha de livro, onde comumente só cabem elogios irrestritos ao autor e sua obra - joga justamente com o caráter ambivalente da obra de Toral, a saber, seu trânsito entre arte e ciência. São reveladoras, entretanto, as relações de poder maliciosamente desveladas com essas palavras.

Referimo-nos ao tácito poder simbólico de que goza a ciência em demérito da arte. $\mathrm{O}$ aspecto mais palpável dessa relação de poder desigual reside na legitimação institucional da ciência por meio das Universidades. Até a virada do séculos XIX para o XX as então assim chamadas Belas Artes contavam com seu próprio locus de legitimação institucional e as convenções formais da Pintura Histórica eram academicamente ditadas (TORAL, 1997, pg. 241). Devido à evolução heterodoxa das artes no século passado, atualmente há outros mecanismos de legitimação das mesmas para além da tradição acadêmica. $O$ caso dos quadrinhos é ainda mais singular, mas, no caso específico de um quadrinho que se pretende histórico, isso é, fundamentado na Ciência Histórica, a especialização acadêmica nessa disciplina por parte de um autor de quadrinhos é bastante significativa para sua "validade científica”. Adiós, Xamigo (...) é a primeira história em quadrinhos publicada em uma tese 
historiográfica no Brasil, ou seja, em que o meio quadrinístico é utilizado como uma forma de narrativa e exposição da História e em que tal feito é institucionalmente sancionado em um das mais importantes universidades do país. A qualidade científica da obra, no entanto, não provém de "autoridade acadêmica", mas por sólida fundamentação metodológica em pesquisa histórica na base de sua produção. As razões e justificativas desse experimento ao mesmo tempo artístico e científico são discutidas pelo autor na introdução de sua tese e são um ponto de partida para discutirmos essa forma de narrativa histórica.

Dividimos essa discussão em duas partes: a primeira (5.1.1.) refere-se à inserção da obra Adiós, Xamigo (...) no modelo genérico do quadrinho histórico e problematiza, portanto, a ficcionalidade na narrativa gráfica de intenção histórica; a segunda (5.1.2.) refere-se à sua função didático-histórica, isto é, de comunicação da ciência histórica, e se refere mais especificamente à questão da historicidade da narrativa gráfica apesar de seu caráter ficcional. Após essa discussão teórica mais abrangente (5.2.), analisaremos seu resultado prático, a história em quadrinhos propriamente dita, bem como outras histórias do autor, em busca dos problemas mais pontuais envolvidos nessa forma didático-histórica de quadrinismo. 


\subsection{2 . O quadrinho histórico como derivação do romance histórico}

A primeira e mais evidente resposta que nos surge ao perguntarmo-nos que forma dá Toral à história que pretende narrar é a de um quadrinho histórico. $\mathrm{O}$ conceito de gênero que cunhamos a partir do modelo conceitual do romance histórico de Lukács nos parece o mais interessante para definir a obra Adiós, Xamigo (...) por suas semelhanças com o mesmo. Antes de nossa fundamentação conceitual para o gênero, já era colocada sua utilização. Toral já se referiu ao gênero de quadrinhos a que se dedicou preferencialmente como "quadrinhos históricos":

\footnotetext{
A inclusão dos quadrinhos em bibliografias de escolas fez com que as vendas aumentassem com tiragens inteiras pré-vendidas praticamente. (...) Repare também como "quadrinhos históricos" estão em alta. Todo mundo descobriu que os "jovens" gostam e podem aprender história de uma forma nova e com a qual se identificam. (TORAL, In: RAMOS, 2009)
}

Há uma clara indicação de intencionalidade autoral no sentido de definir (mesmo que de maneira ambígua) um segmento produtivo. Também é claro para o autor que o gênero quadrinístico em questão possui sua motivação social em um amálgama de razões didáticas e mercadológicas.

Atualmente a teorização da linguagem dos quadrinhos vem chamando a atenção para suas especificidades, atentando especialmente para os perigos de sua comparação com outras linguagens artísticas, como a literatura, que guarda suas próprias características formais. Por um lado, se existe uma estrutura quadrinística específica, o fazer quadrinístico dialoga na maior parte das vezes com essas outras linguagens que lhe são historicamente antecessoras. No caso de Toral, a pintura e a literatura "histórica" (ou seja, de época, produzidos em determinado período) lhe servem de fonte documental para a reconstituição histórica (isto é, representação da História a partir do ponto de vista do presente). Por outro lado, é evidente também o diálogo do autor com a tradição dessas linguagens na própria elaboração de seu estilo quadrinístico, de sua forma de narrar em imagens e textos. Esse duplo sentido do adjetivo "histórico", como veremos adiante, se desdobra na produção do quadrinho histórico 
entre as fases de sua pesquisa, pois suas fontes documentais são "históricas" (naquele primeiro sentido); e a de sua escrita, que é "histórica" (no sentido aproximativo de "historiográfica").

O quadrinho histórico é menos um herdeiro do romance histórico e mais um derivado do mesmo. Não segue sua linha de descendência como se tratasse da continuidade de uma tradição. A metáfora da derivação nos parece mais adequada. A tarefa de dar forma narrativa ficcional à história, que antes seguia o curso da literatura, deriva sua torrente para um novo afluente, os quadrinhos.

A referência do autor à aproximação de seu quadrinho da estrutura do romance se dá quando se refere a expressão "romance gráfico" (TORAL, 1997, p. XX) - variante aportuguesada da corrente expressão anglófona graphic novel - mas também na seguinte comparação:

\footnotetext{
Assim como o romancista, o historiador, ou talvez como uma mistura dos dois, o autor de história em quadrinhos usa uma técnica narrativa especial como caminho para a reconstituição e como recurso para prender a atenção do leitor. A estrutura narrativa é quase um romance, a referência é rigorosamente histórica, no sentido de seu compromisso com o real. As maneiras de pensar dos personagens da história, marcando a presença do indivíduo como fator a ser considerado na análise, nos trazem a sua visão de mundo. (TORAL, 1997, p. XX)
}

André Toral considera a narrativa histórica como um "relato de acontecimentos verdadeiros". Entretanto, ao se valer de elementos ficcionais para cobrir as lacunas da trama histórica que pretende expor, lança-se em terreno pouco mais acidentado. Nesse sentido, a ficcionalidade intrínseca à narrativa quadrinística de Toral não é estorvo à compreensão histórica, pois visa cobrir as inevitáveis lacunas da construção historiográfica por meio da imaginação artística, que não é nesse caso livre de rédeas, mas elaborada a partir de referências documentais históricas e buscando uma verossimilhança com relação a essas referências. Segundo o próprio autor:

Para a reconstituição do período e da maneira de pensar das pessoas utilizo as clássicas fontes primárias usadas em história e outras, além das imagens, como romances, poesia [como 
explícito na figura 5], moda etc. (...) A linguagem de arte sequencial permite a utilização dessa informação ficcional e "histórica" contemporânea ao conflito [da Guerra do Paraguai]. Abre, portanto, a possibilidade de utilizar toda forma de interpretação marcadamente subjetiva produzida durante o período que nos interessa. (TORAL, 1997, p. XIX)

O objetivo maior de Toral ao construir uma narrativa sobre a Guerra do Paraguai na forma de arte sequencial é a reconstituição vívida do período. Entre os principais elementos necessários para alcançar essa vividez encontram-se essa dimensão subjetiva de que nos fala o autor. Em outra passagem, ele é mais direto:

(...) a história, como uma obra de ficção, apresenta homens em ação, necessitando de certo sentido do psicológico para dar-lhes vida (...). Foi isso que procurei fazer ao construir um roteiro ficcional que serve como fio condutor para a reconstituição de época. (TORAL, 1997, p. XV)

Essa dimensão de reconstituição hipotética da experiência social, particularmente exemplificada através da representação de vivências dos sujeitos históricos é um dos elementos centrais do modelo lukácsiano de romance histórico e sua execução requer o uso da imaginação histórica, isto é, da narrativa ficcional fiel à representação histórica. Esse é um dos elementos que mais aproxima a obra Adiós, Xamigo (...) do modelo de quadrinho histórico que esboçamos a partir das linhas gerais do romance histórico lukácsiano.

Para comunicar a tragédia humana contida na experiência histórica das guerras a forma artística, no caso da história em quadrinhos, é mais adequada que a tese. Isso se deve à categoria da particularidade que, segundo a estética lukácsiana, é própria da arte e a distingue da ciência, essa voltada para a compreensão do universal (LUKÀCS, 2010). Poderíamos resumir essa diferenciação assim: enquanto que a tese de Toral está preocupada com as explicações históricas e problemas levantados pela iconografia da Guerra do Paraguai, seu quadrinho trata de imaginar sobre bases históricas como tal guerra teria sido particularmente vivida por sujeitos históricos comuns. Além de representar sujeitos históricos que habitualmente não são observados pela historiografia tradicional (geralmente, por escassez de fontes históricas) a própria representação artística, interessada em suas particularidades, erige uma visão mais palpável de como a história pode ter sido fluida por seus sujeitos. 
Tomando ainda como referência teórica a estética lukácsiana, podemos dizer que Toral se lança aos dois lados da fronteira entre arte e ciência tal qual delimitada pelo pensador húngaro. A parte I de sua tese conteria a representação artística da história, espécie de romance histórico em quadrinhos. A parte II de sua tese seria a apresentação científica da história, onde a exposição explicativa seguiria a forma academicamente consagrada de exposição historiográfica. As características fundamentais que dividem os dois lados dessa fronteira seriam as categorias da particularidade e da universalidade que, segundo tal teoria, distinguem respectivamente a arte da ciência sem que tais partes se excluam na prática, mas apenas se dividam conforme a centralidade de uma ou de outra no seu fazer.

A estética lukácsiana que aqui citamos é anterior ao processo historiográfico conhecido como "retorno da narrativa", que se deu a partir das tendências historiográficas pós-estruturalistas dos anos setenta. Toral evoca justamente historiadores desta tendência em sua justificativa teórica, no caso, Robert Darnton e Paul Veyne. Entretanto, como pondera Eric Hobsbawm (HOBSBAWM, 1998), a tal "volta da narrativa" na historiografia não era propriamente uma revolução historiográfica bem como incorria em certo exagero em sua tentativa de explodir as fronteiras entre a historiografia e a narrativa histórica ficcional, entre os âmbitos da ciência e o da arte. Toral integra a unidade desses âmbitos da seguinte maneira:

\footnotetext{
Além da veracidade, outra característica importante do relato histórico é sua capacidade explicativa. "Explicar" significa mostrar o desenvolvimento da trama histórica, fazendo com que se torne compreensível. (...) Buscar as causas implica em relatá-las da maneira mais penetrante, descobrindo aspectos não factuais. História é narração; não é determinação nem tampouco explicação. "Explicar" melhor é relatar melhor. (TORAL, 1997, p. VIII).
}

Podemos observar que no período em que a tese de Toral se insere, a questão da "volta da narrativa" era levantada como uma reviravolta contra os modelos explicativos estruturalistas que até então vigoravam. O retorno a formas narrativas que reaproximavam a historiografia da literatura foi responsável por muitos excessos na desconfiguração de suas respectivas responsabilidades. Apesar de evocar justificativas teóricas comumente chamadas de pós-modernas, Toral, ao fim e ao cabo, está mais próximo do modelo lukácsiano, que 
mantém as definições de fronteiras entre história e literatura. Toral narra a história com elementos de ficcionalidade, mas sua narrativa quadrinística ficcional não se confunde com sua apresentação historiográfica do tema, que constitui a segunda parte da tese.

O principal elemento ficcional de sua narrativa é constituído por seus protagonistas, que não são personagens históricos em um sentido factual, pois nunca viveram de fato, mas são historicamente representativos e nesse sentido verossímeis. Não são os grandes personagens da história, que entraram para as narrativas historiográficas tradicionais no papel de heróis, mas personagens de pouco vulto histórico e que por isso mesmo nos possibilitam imaginar como a história pode ter sido vivenciada por pessoas comuns. A condução narrativa por meio de personagens socialmente medianos, ou seja, tipos historicamente representativos de uma classe, gênero, profissão, etc. Trata-se de uma característica eminentemente aproximada do modelo de romance histórico, segundo o qual o foco nesse tipo de personagem é capaz de representar os processos e fatos históricos em sua dimensão socialmente mais abrangente, ou seja, por meio da representação particular da vivência de um processo histórico podemos ver seu aspecto mais universal, uma vez que se dá por meio da vida de um personagem historicamente representativo.

$\mathrm{Na}$ narrativa há também a alternância de foco entre quatro personagens distintos, com vistas a apresentar as vivências de figuras de diferentes classes, regiões e nacionalidades. São eles: um cidadão da elite urbana carioca, Jorge Souto; dois vaqueiros baianos, Silvino e Sebastião (vulgo Tião); e, por fim, um soldado paraguaio, de nome Ladislao Iturbe (apelidado Lalo). A história se divide em duas partes, que retratam respectivamente a história dos dois lados envolvidos no conflito, o brasileiro e de seus aliados; e o paraguaio. A primeira parte, "Voluntários da Pátria", alterna o foco entre Jorge e os dois baianos, que servem no mesmo batalhão; a segunda parte é centrada no personagem paraguaio e é intitulada com seu nome. Ao alternar o foco entre personagens que têm suas vidas cruzadas em um processo histórico, Toral busca também uma visão abrangente do mesmo, apresentando-o a partir de diferentes partes. Tal cruzamento visa à representação das diferenças classistas e regionais internas a uma nação, no caso a brasileira então em construção nesse processo bélico; e depois às diferenças nacionais entre os países envolvidos no conflito. 
Os "grandes vultos" históricos do episódio, como as lideranças políticas dos lados brasileiro e paraguaio, Dom Pedro II e Francisco Solano Lopez, respectivamente, aparecem de forma episódica. Outros personagens históricos de menor projeção também são representados, como é o caso dos pintores históricos Vitor Meireles de Lima, responsável por obras como "A Primeira Missa no Brasil" e "Combate Naval do Riachuelo", essa última sobre episódio da Guerra do Paraguai; e Candido López, pintor histórico argentino que perdera a mão direita durante a guerra. Aparece também Esteban Garcia, um dos poucos fotógrafos que atuaram no "teatro de operações" da guerra. Esses últimos personagens, menos "vultosos", foram estudados por Toral em sua tese e ganharam nova vida em seu quadrinho.

Não à toa os personagens ficcionais centrais de Adiós, Xamigo (...), Jorge e Ladislao, teriam sido supostamente colaboradores de veículos da chamada imprensa ilustrada do período que de fato existiram: Jorge escrevia ocasionalmente para A Semana Illustrada, dirigido por Angelo Agostini; Ladislao em meio à guerra tornara-se integrante da redação do Cabichuí, espécie de panfleto de Lopez em forma de jornal, como ilustrador improvisado. Tratam-se de periódicos também pertencentes ao corpus documental da tese que antecede ao quadrinho. Esse detalhe da caracterização dos personagens corresponde à necessidade de representar de forma mais minuciosa o grosso da matéria-prima documental da obra, a saber, as fontes iconográficas: pintura, gravura, ilustração, fotografia, etc. Veremos no sub-capítulo seguinte que é nessa operação de dar uma forma quadrinística às fontes históricas que atua o mister historiográfico do quadrinho histórico. 


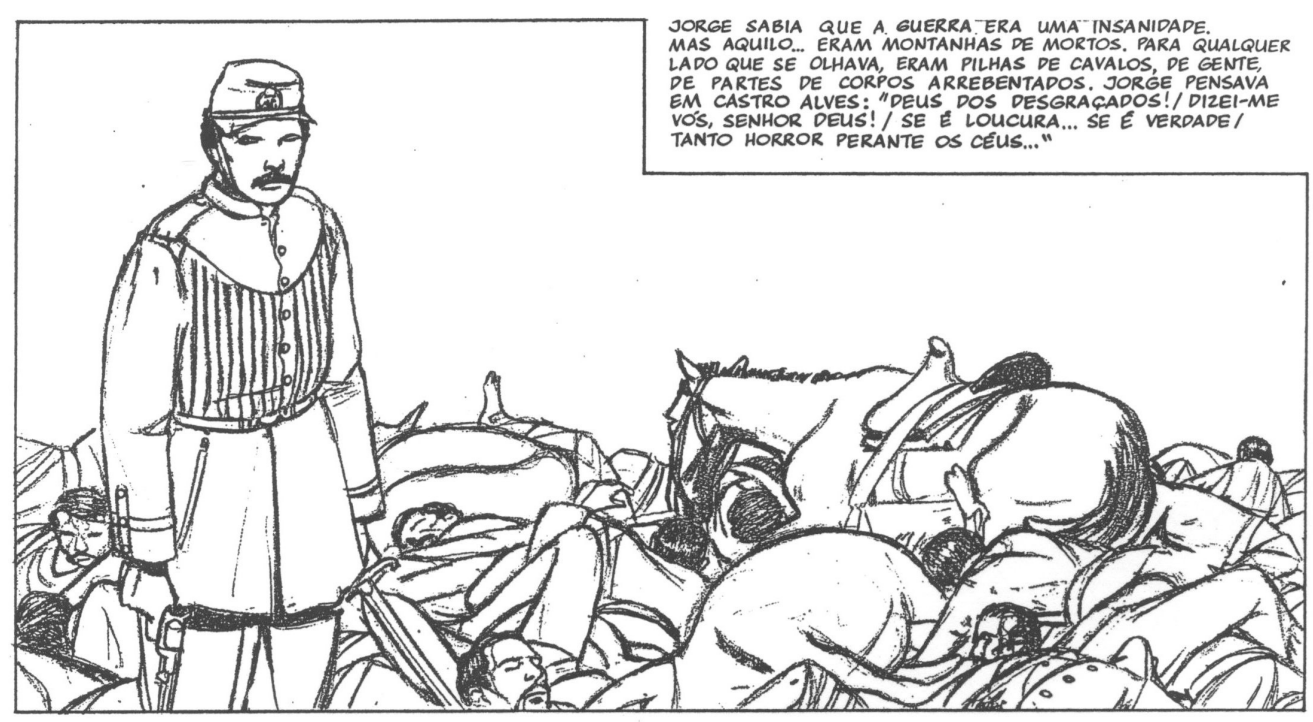

Fig. 5 (TORAL, 1997, p. 45)

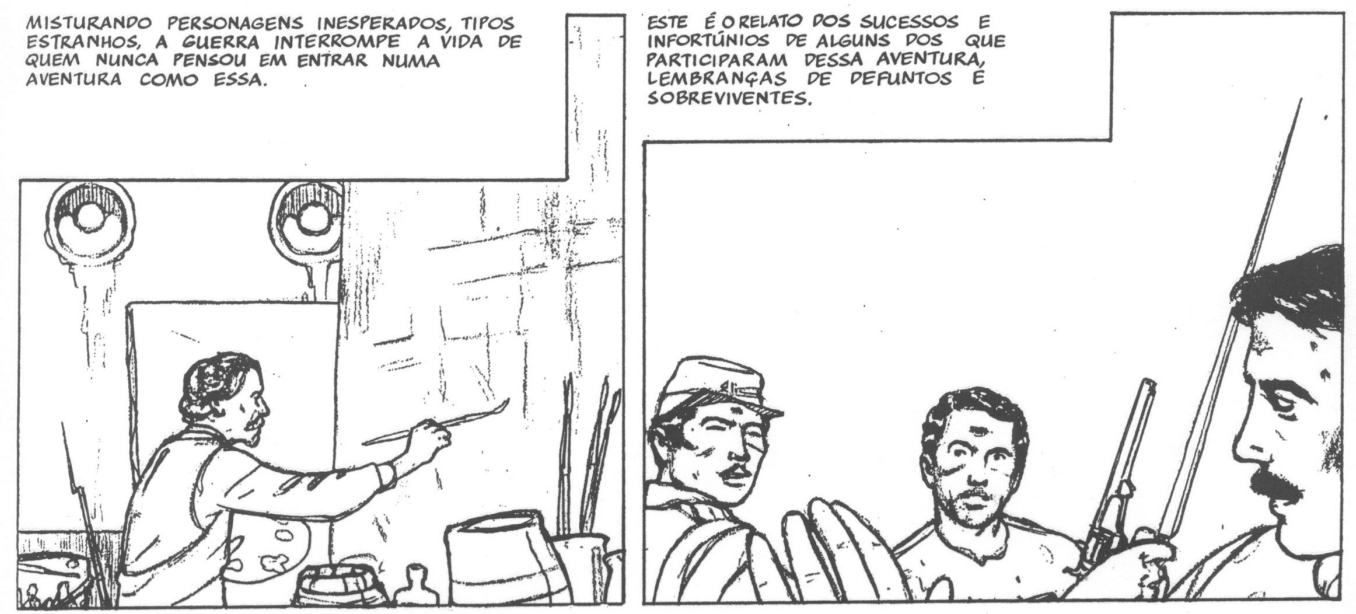

Fig. 6 (TORAL, 1997, p. 1) 


\subsubsection{O quadrinho histórico como reconstituição histórica ou historiografia}

Se do ponto de vista da ficcionalidade da narrativa a referida obra de Toral se aproxima do modelo teórico lukácsiano do romance histórico, do ponto de vista historiográfico da narrativa há uma aproximação do modelo teórico-metodológico proposto pela Escola dos Annales e faz jus, principalmente, à problematização crítica das fontes históricas. Tal escola historiográfica caracterizou-se pela revisão da noção de documento enfatizando sua característica de constructo social em oposição à noção positivista anterior que via os mesmos como dados.

O autor é bastante claro quanto à intenção comunicativa por trás da escolha pela linguagem quadrinística e da sua forma específica de trato do conteúdo histórico:

Busca-se, através do emprego dessa linguagem [a quadrinística], encontrar uma forma de exposição interessante o suficiente para "arrumar" os dados sem, com isso, perder a possibilidade de criticar o documento (...) (TORAL, 1997, p. XV)

Tendo sido fundamentada primordialmente em pesquisa histórica sobre bases documentais iconográficas, a reconstituição quadrinística da História empreendida por Toral segue duas vias no que se refere ao aspecto visual. A primeira via é a reconstituição visual da época, isto é, a "arrumação" dos dados visuais contidos nos documentos iconográficos. Os dados visuais em questão são utilizados na composição da ambientação, dos figurinos, objetos, em suma, da cultura material própria do período. Neste sentido, há um uso do documento histórico que é particular de formas de representação visual da História, e nesse pormenor o quadrinho histórico aproxima-se da pintura histórica. A segunda é a da apresentação e representação crítica desses mesmos documentos visuais e transcende a primeira. Trata-se de uma exposição narrativa do próprio processo de construção, circulação, recepção dessas imagens, em suma, dos usos e funções da iconografia que Toral pesquisou em sua tese. À luz da distinção teórico-metodológica cristalizada por Jacques Le Goff (1990, p. 526), podemos dizer que Toral perfaz o processo historiográfico retroativo de apresentar seus documentos como monumentos, ou seja, não como fontes do historiador no presente, mas, 
sim, como produtos do passado com vistas à perpetuação de sua memória.

A primeira via, a reconstituição visual de época, talvez porque a mais evidente, é geralmente a primeira a ser lembrada quando da crítica de representações visuais da História. Essa propriedade de nos "fazer ver" a história em sua aparência física, de nos brindar com a percepção visual de outro período por meio de imagens artisticamente reelaboradas a partir de fontes iconográficas, nos leva a compará-lo com os pintores históricos atuando como espécie de "pintores historiadores", como defende Peter Burke (2005). Toral (1999, p. 135-136) evoca Walter Benjamin, ao avaliar o impacto social da pintura histórica do período, que pôde ser contemplada por multidões nas grandes exposições, mas que não teve maior efeito no prestígio da guerra que as imagens de sua sangrenta realidade, difundidas por meio da fotografia e da litografia na imprensa ilustrada. Defende que não apenas a linguagem da pintura não podia arrebatar as "massas" (como passaria mais tarde a ocorrer com o cinema e os quadrinhos) por sua própria essência, bem como por não possuírem um conteúdo de transformação social. De fato, por conta da emergência da reprodutibilidade técnica, a produção de pinturas históricas hoje não "faz mais sentido", isto é, por não possuir mais aquela incidência social, não produz o mesmo efeito comunicativo da cultura histórica. Pelo mesmo motivo, tal tarefa se transferiu no campo das artes para os quadrinhos e para o cinema, e em razão disso podemos considerar o quadrinho histórico como derivativo também da pintura histórica.

Por certo que nem toda obra de pintura histórica era assim esmerada no realismo visual, como demonstra o próprio Toral em sua crítica da pintura do período da Guerra do Paraguai. Talvez menos ainda o sejam as histórias em quadrinhos que, imbuídas na vontade de representar um período histórico, se lancem antes ao trabalho de pesquisa iconográfica necessária para a boa representação da cultura material do período representado. Nesse caso, Toral cita como influência a tradição da "linha clara" de Hergé e Edgar Pierre Jacobs (TORAL, 1997, p. XIV). Infelizmente, o caso de Toral e suas influências quadrinísticas são excepcionais, pois, como pondera Vergueiro (2003) "Nem todos os autores [de quadrinhos] tem uma preocupação especial em retratar fielmente os ambientes históricos específicos, caracterizando de forma apropriada costumes, hábitos, vestimentas, locais ou regimes políticos dominantes."

Entrevista ao site Omelete. Disponível em: http://omelete.uol.com.br/quadrinhos/os-quadrinhos-nas-aulas- 
Nessa citação são sugeridos os elementos para além do simples aspecto superficial da história (entre os quais o aspecto visível) que, segundo o modelo lukácsiano, constituem a pedra de toque do romance histórico e que pode ser estendida para a avaliação do quadrinho histórico. Não basta uma boa representação do cenário e dos figurinos em belas imagens. Há que se reconstituir os aspectos da história vividos por seus sujeitos, isto é, as formas historicamente particulares como pensavam e agiam.

Há outra crítica de Lukács (2010) que pode apontar para certa superação por parte das narrativas visuais, como os quadrinhos ou o cinema, de uma limitação mútua entre a pintura e a literatura. A propósito da prosa naturalista da segunda metade do século XIX, em sua obra Narrar ou descrever, há uma crítica ao descritivismo gratuito e supérfluo da realidade visível, que, segundo ele, não caberia à forma literária. A codificação verbal da realidade visível não possui o mesmo efeito estético que a representação propriamente visual da mesma, tarefa mais pertinente à pintura. Por outro lado, os usos e sentidos de um objeto podem ser muito melhor representados na narrativa literária. Nesse sentido, a integração quadrinística de códigos verbais e visuais em uma espécie de síntese entre literatura e pintura resolveria tal "impasse formal". Talvez por isso não fosse exagero afirmar que o quadrinho histórico é capaz de realizar uma síntese entre o romance histórico e a pintura histórica.

Por certo que o hibridismo resultante da interação entre as diferentes linguagens que antecederam os quadrinhos e que neles se integram em uma síntese quase inextrincável torna sua dissecação comparativa bastante simplista. Isso se dá pela própria natureza de sua leitura, onde a apreensão visual dos quadros é, geralmente, mais rápida que a fruição da narrativa que conduz de um quadro a outro, de modo que a visualização do quadro não requer maior atenção que a compreensão do enredo, onde se inserem as relações entre os personagens. Em suma, no quadrinho um objeto bem representado é um dado visual instantaneamente efetivo que contribui para a beleza da representação verossímil, mas que jamais poderia encobrir uma história mal contada, enquanto que na literatura as linhas dedicadas à descrição física de um objeto de fato perturbam o andamento do enredo. Além disso, não possuem nesse último caso o mesmo efeito de "fazer ver", pois são codificadas em palavras para depois serem 
decodificadas em imagens mentais de vaga definição objetiva. Toral é consciente desse aspecto:

\begin{abstract}
Existe um pensamento plástico, como existe um pensamento matemático ou verbal. As artes permitem aos homens manifestarem uma série de valores que só podem ser apreendidos e notados através de um sistema autônomo de conhecimento e de atividade (...). As representações expressas pelas obras de arte nos remetem para as formas de pensamento e representações visuais que uma sociedade faz de si mesma e das demais. Se a especificidade do tipo de informação fornecido pelo material visual nos parece bem marcada, resta o problema de como fazer para se transmitir esse conhecimento. Descrever uma obra de arte implica em reduzi-la a elementos comuns com a linguagem. (...) A imagem plástica vai direto ao cérebro sem exigir intermediário verbal. Ou seja: nunca uma descrição vai poder dar conta de uma imagem. (TORAL, 1997, XII).
\end{abstract}

Entre o simples "fazer ver" a História por meio dos quadrinhos, isto é, a representação fiel e detalhada da cultura material de um determinado período por meio de imagens, e a reflexão sobre a historicidade desta cultura material, isto é, sua representação historicamente problematizada, há uma grande distância qualitativa na ordem da disciplina histórica. Como ressalva Marcos Silva acerca da pouca ênfase (a qual a própria historiografia por vezes incorreu) em tal problematização: “Correu-se o risco de reduzir o trabalho com Cultura Material ao arrolamento de diferentes artefatos, sem pensar sobre sua situação num mundo de homens e mulheres que se relacionam através de símbolos e poderes e se fazem por diferentes vias." (SILVA, 2006, p. 84).

Em Adiós, Xamigo (...) essa problematização histórica está presente na representação de boa parte da cultura material da época, mas há uma problematização ainda mais sofisticada, que é a daquele tipo de material especificamente estudado por Toral em sua tese: pintura, imprensa ilustrada, fotografia, etc. É preferencialmente nos casos desses documentos que o autor narra seus usos e funções naquele dado contexto. Por meio do recurso à crítica dos documentos, essa narrativa quadrinística se aproxima da historiografia em seu rigor metodológico. A diferença encontra-se na forma de exposição dessa crítica, que no quadrinho histórico de Toral surge episodicamente por meio da representação desses documentos em seu contexto de produção, circulação, recepção etc. Tais passagens são como pontos que costuram a linha narrativa ficcional sobre o pano de fundo histórico. 
Essa costura entre historiografia e ficção em quadrinhos é, de fato, uma forma de narrativa histórica muito interessante por possibilitar uma leitura fruída, vívida e visível da História. Mas do ponto de vista do conhecimento histórico tal fruição possui muitos percalços, nos dois sentidos da palavra: como vantagens e como obstáculos. A grande vantagem está na própria natureza prazerosa da fruição artística, que pode tornar a compreensão histórica mais interessante. Os obstáculos dizem respeito principalmente à distinção por parte do leitor entre fato histórico e ficção, emaranhados no enredo narrativo. Mesmo que os elementos ficcionais sejam historicamente informados, surge aí o problema de avaliação da verossimilhança histórica dos mesmos. Nesse caso, a leitura de um quadrinho histórico deve se orientar justamente por sua especificidade de ser uma forma imaginativa de historiografia que representa como certos processos históricos podem ter sido vividos por sujeitos hipotéticos e não por sujeitos que viveram de fato.

A distinção entre fato e ficção também colide com a preconcepção de uma fruição espontânea e imediata da obra. Nesse sentido, a ideia de que a formatação quadrinística da matéria histórica seria mais “interessante” (TORAL, 1997, p. XV) é problemática. À primeira vista parece se tratar da simples evocação do fator "entretenimento", em que a fruição quadrinística é considerada por si só mais agradável ou atraente. Mesmo que haja a retenção de toda uma caracterização de época em uma leitura descompromissada do quadrinho histórico, apenas a leitura disciplinada da obra, aliada a um estudo de sua matéria-prima histórica, pode aprofundar tal distinção. Para tanto, além da mediação escolar por meio da disciplina histórica, ou do ensino específico para um estudo disciplinado das artes em geral, é de grande valia que o material de pesquisa por trás do quadrinho histórico seja apresentado ou resgatado em sua forma primária.

Toral apresenta sua matéria-prima em estado bruto em três diferentes meios. A primeira delas é a própria exposição acadêmica da pesquisa iconográfica em sua forma tradicional que constitui a segunda parte de sua tese Adiós, Xamigo (...). A segunda é um anexo ao álbum Adeus, Chamigo Brasileiro, no qual a história em quadrinhos foi publicada. Nele são apresentadas algumas imagens dos documentos pesquisados pelo autor ilustrando um texto de contextualização geral e uma cronologia da Guerra do Paraguai muito 
aproximados dos moldes do texto dito didático, ou seja, o texto sintético e esquemático. A diagramação também é idêntica ao padrão mais comum aos livros didáticos em geral, disposta em duas colunas que intercalam texto e imagem. Se nessas duas formas de apresentação complementares ao quadrinho há certa diferenciação de público, que divide o interesse acadêmico daquele da cultura histórica mais ampla, do assim chamado "grande público", a última forma de apresentação da pesquisa é veiculada independentemente do quadrinho e serve à função de divulgação científica de sua tese. Trata-se de um pequeno artigo acompanhado de uma seleção da iconografia pesquisada publicado na Revista Superinteressante, de setembro de 1999, e intitulada Guerra no Mercosul (TORAL, 1999b). À época dessa divulgação não existiam as revistas especializadas de história que hoje se encontram nas bancas de revistas; a revista em questão possuía essa característica de trazer eventualmente textos integralmente produzidos por pesquisadores.

Por fim, cabe ressaltar que essa "forma imaginativa da história" não pode se confundir com a historiografia. Embora seja embasada em pesquisa cientificamente orientada e possua elementos que a aproximam da narrativa historiográfica, a intromissão ficcional faz do quadrinho histórico algo diferente do que se possa chamar de quadrinho historiográfico. A possibilidade de se expor e narrar a história de forma artística (do ponto de vista da forma quadrinística, e não da ficcionalidade) uma tese científica não está excluída, mas não é exatamente o caso da narrativa de Adiós, Xamigo (...). 
5. 1. 4. Esquadrinhando Adiós, Xamigo (...)

Lancemo-nos agora à análise dos elementos propriamente quadrinísticos da obra Adiós, Xamigo (...) com o propósito de descobrir a forma do quadrinho histórico em sua técnica - isto é, através de que estilo, recursos, expedientes etc. - a história adquire sua forma quadrinística. 


\section{1. 4. 1. Realismo visual}

A característica mais evidente do quadrinismo de Toral é o seu realismo. O realismo em questão pode ser entendido tanto como sua preocupação com a representação da realidade, seja histórica ou contemporânea, quanto com seu estilo de representação visual. Tratam-se de concepções de realismo que remontam a suas tradições na literatura e na pintura e, novamente por extensão comparativa, podemos dizer que Toral é um quadrinista realista.

Em termos de aparência imediata, seu quadrinho como um todo se assemelha aos quadrinhos didáticos da EBAL da metade do século $\mathrm{XX}$, com seu desenho acadêmico e sua narrativa linear. Mas difere completamente quanto a suas intenções cognitivas e formativas, pois esses últimos eram versões quadrinísticas da didática histórica escolar da época que comunicavam primordialmente a cultura histórica nacionalista e oficial destronada no pósoitenta-e-quatro por um paradigma pedagógico de consciência crítica da história. Essa é a diferença fundamental do quadrinho de Toral, que é por isso a expressão mais significativa da cultura histórica de viés crítico nos quadrinhos, e sua semelhança em termos de representação visual com aqueles antigos quadrinhos não se verifica na postura realista e cientificamente fundamentada (para além da concepção positivista factual) com relação à história.

O quadrinista se vale, portanto, de um desenho bastante acadêmico, respeitando regras de proporcionalidade, perspectiva, etc. Seus contornos em grafite também remetem à litografia e carregam assim sua qualidade esfarelada, que difere essa técnica da precisão da linha traçada a tinta. Em termos de acabamento final, há duas versões: a da tese, em que se apresenta apenas a arte final gráfica em preto e branco (e pela qual optamos preferencialmente na ilustração do presente capítulo); e a do álbum, em que é acrescentado o elemento pictórico através de uma colorização em paleta aquarelada e, portanto, de tonalidades aguadas e suaves.

Seu desenho pode ser comparado por sua figuração sutilmente indefinida a uma fotografia levemente desfocada. Seu colorido, no caso da versão em livro, remete, por sua vez, ao recurso cinematográfico de esbranquiçar a película quando se trata de representar memórias, sonhos, etc., ou seja, imagens mentais e, portanto, menos “palpáveis". Seguindo a 
comparação com o cinema, podemos quem sabe depreender do desenho de Toral certo distanciamento da espécie de realismo cinematográfico que explora justamente o efeito “tátill”, para usar expressão de Walter Benjamin (1995), ou então, que explora o "efeito do real", segundo Marc Ferro (1980).

Há também em seu estilo uma interessante referência às próprias fontes iconográficas que o autor utiliza para sua reconstituição visual da História. Seu desenho grafitado também pode ser comparado às imagens da imprensa ilustrada da época, geralmente litografadas. A imprensa ilustrada era majoritariamente dedicada à representação satírica dos fatos através da representação caricatural. A caricatura, cuja etimologia deriva provavelmente ao verbo italiano caricare, "carregar" (FONSECA, 1999, p. 17), é uma forma de representação exagerada da realidade e, portanto, desmedida, distorcida. Tal postura representativa difere da realista ou naturalista, que busca manter as proporções do seu objeto. Colhemos, como exemplo desse processo, a figura 7, em que Toral contrasta uma caricatura da imprensa ilustrada da época com uma representação mais proporcional dos fatos. A caricatura possuía todo um sentido político (exemplar de certo nacionalismo elitista) que é subvertido pela representação histórica de Toral (essa mais crítica para com as condições desfavoráveis do serviço militar e mais generosa para com as classes populares).
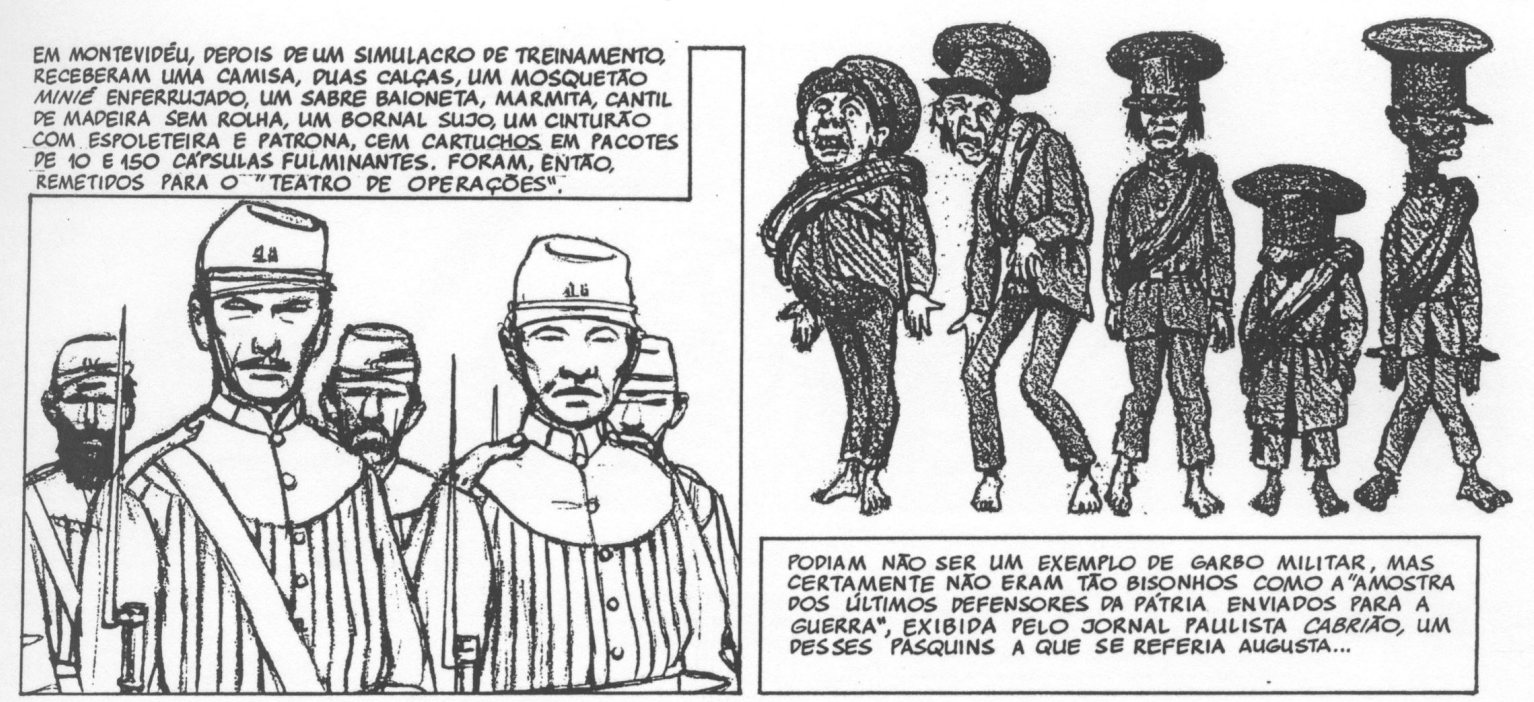

Fig. 7 (TORAL, 1997, p. 25)

Finalmente, seu estilo gráfico também se refere à pintura histórica do período. Remete às técnicas mais utilizadas no século XIX para os estudos dessas pinturas, geralmente realizadas em grafite ou carvão. É interessante notarmos o detalhe de que na arte final do 
quadrinho de Toral utiliza-se a técnica usual dos estudos prévios à composição pictórica (que é, diga-se de passagem, singular também na finalização dos quadrinhos, geralmente feita à tinta preta). Em seu estudo iconográfico, Toral constatou, a propósito do pintor Vitor Meireles de Lima, que a fidelidade realista de representação dos fatos se fazia mais presente nos seus estudos do que em suas telas (TORAL, 1997, p. 292-293). Isso, porque neles o artista estava comprometido com a coleta de dados para a composição da segunda, que por sua vez era realizada segundo convenções formais e idealizações que respeitavam muito mais a ideologia de Estado, seu mecenas, que a tragédia humana da guerra. Toral, por meio da representação realista da história, pode redimir de certa forma o trabalho desses pintores, como Vitor Meireles [figs. 6, 9, 10] ou Cándido López [figs. 7 e 19], que por contingências de seu tempo não puderam ser tão fiéis à história e suas vítimas. Toral também faz jus, ao tornar público em seu quadrinho o estudo de Meireles, ao papel redentor do historiador, como preconizou Benjamin em suas Teses sobre a História, em relação aos oprimidos do passado, no caso todos os "voluntários" forçados da pátria, arrancados de suas vidas e colocados nas primeiras fileiras dos campos de batalha para morrerem em seu nome. Seguindo a evocação benjaminiana, nos valemos por fim da bela imagem que esse pensador ergueu para ilustrar o trabalho do historiador e comparamo-la com a imagem erguida por Toral na página 73 [fig. 9]. Segundo Benjamin, o historiador dispõe, para reconstruir a história, apenas de suas ruínas. Em Adiós Xamigo (...) Vitor Meireles retratou a Batalha de Humaitá observando seu desenrolar e seu desfecho, podendo após o último pisar em suas ruínas. Retratou-a, contudo, para laurear o vencedor, idealizado na figura da nação, dando atenção a suas vítimas apenas em seus esboços. Toral, a partir das imagens arruinadas da guerra, muitas das quais foram esquecidas ou nem mesmo vieram à tona na época (como os esboços do pintor), ergue um monumento histórico a essas mesmas vítimas, mas também àqueles que legaram documentos sobre a mesma. 


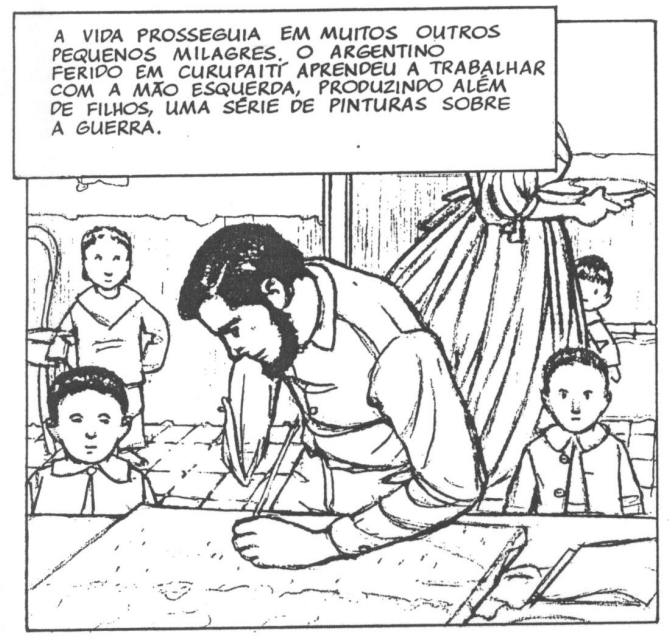

Fig. 8 (TORAL, 1997, p. 115) 
HUMAITA', TERRITÓRIO PARAGUAIO, JULHO DE 1868. NO CHĀO, A PÓLVORA INUTILIZADA PELOS PARAGUAIOS, NO AR UM CHEIRO DE COISA
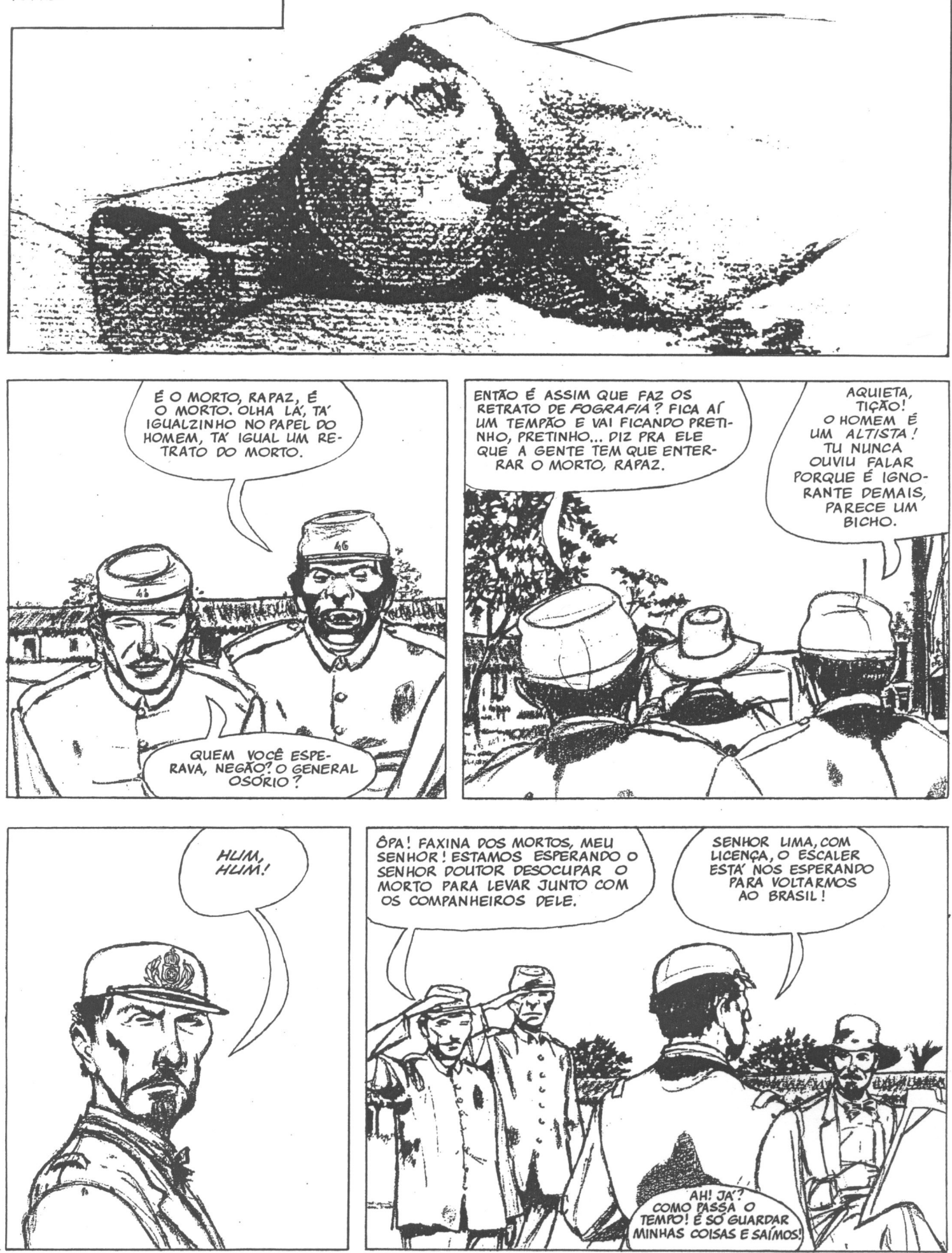

70

Fig. 9 (TORAL, 1997, p. 70) 

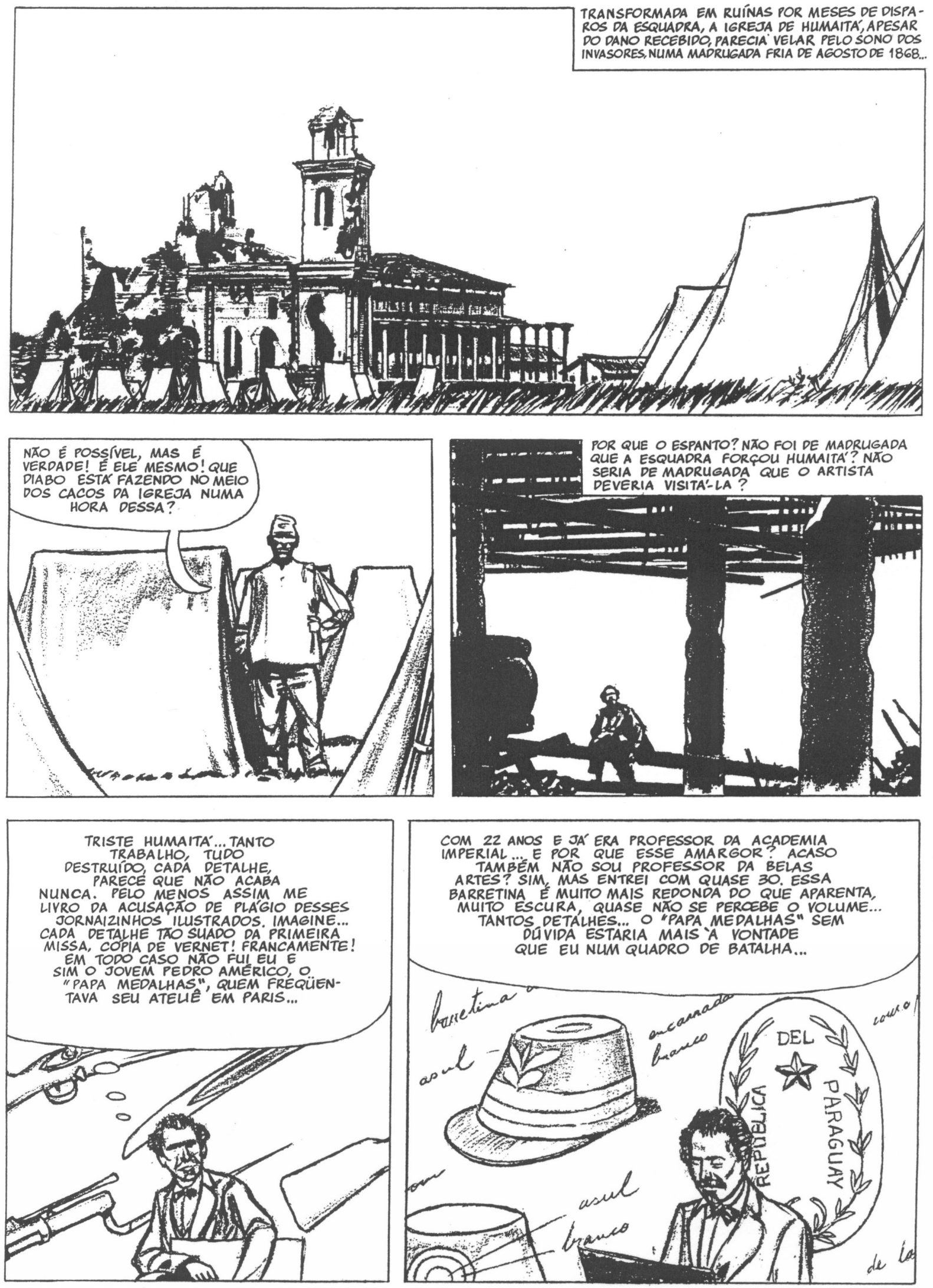

73

Fig. 10 (TORAL, 1997, p. 73) 


\section{2.2.2. Representação da cultura material}

A representação da cultura material no quadrinho de Toral não é reduzida ao imediatamente visível não sendo desprovida de significação histórica. Isso se dá através de sua colocação na estrutura narrativa quadrinística que contextualiza historicamente os usos e funções dos objetos. A tarefa de representar os objetos específicos de um determinado período histórico é bastante árdua, pois requer uma extensa pesquisa para preencher de detalhes cenográficos os muitos quadros de uma história em quadrinhos. Neles, diferentemente da descrição de um ambiente e seus objetos na literatura ou de sua representação na pintura, tal representação não pode ser excessivamente detalhada sob risco de prejudicar o fluxo da leitura. Muitas seqüências inclusive lhe negam a representação, geralmente quando se trata de destacar ações dos personagens em planos de fundo vazio (branco ou colorido). Por conta desse pormenor, Toral usa engenhosas maneiras de representar a cultura material, ao criar sua ambientação.

Tomemos como ponto de partida os quadros fechados em objetos da cultura material [fig. 11 e fig. 12]. O que aparentemente trata-se de um simples recurso à curiosidade visual é uma forma de situar o contexto de uso desses mesmos objetos. Uma xícara de café e o enquadramento de espadas à frente de um churrasco ao fogo de chão situam diferentes ritos sociais em que se desenrolam as cenas e diálogos que antecedem e sucedem os referidos quadros. Outros close-ups focalizam significados intrínsecos da mesma. É o caso das figuras 13 e 14. No centro desses quadros, cordas e grilhões prendem pescoços humanos e se destacam como inegáveis símbolos de representação de relações de dominação cuja significação é histórica, ou seja, não é artificialmente imposta, mas sim formalmente descoberta pelo desenhista. O quadro do comboio de escravos se relaciona a outro quadro pouco anterior em que é representado o recrutamento forçado de trabalhadores rurais baianos (representados pelas personagens de Silvino e Sebastião) atrelados ao sistema coronelista para lutarem na guerra do Paraguai. Ali, ao invés de correntes, víamos cordas. O processo de recrutamento compulsório de trabalhadores pobres do campo é muito bem representado no enredo, em uma situação de emboscada articulada entre as forças armadas e o coronel da região; gostaríamos aqui de enfatizar como a informação visual relativa à cultura material, no caso, a diferença entre a corrente e a corda, podem significar toda uma rede de nuances nas formas de dominação do período histórico em questão. A diferença entre a corrente e a corda é 
a sutil diferença entre as amarras que ligam os senhores e escravos lá, coronéis e peões al

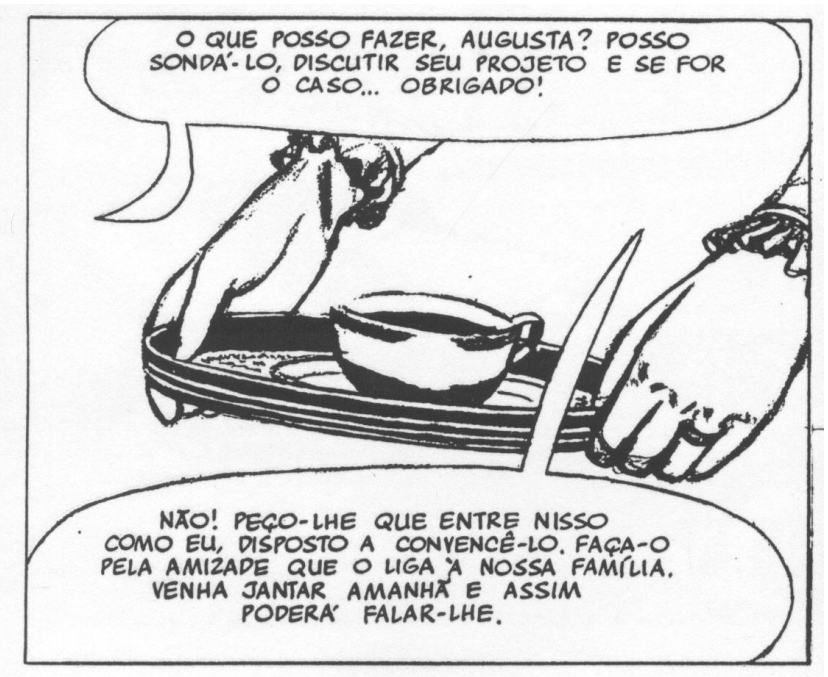

Fig. 11 (TORAL, 1997, p. 18)

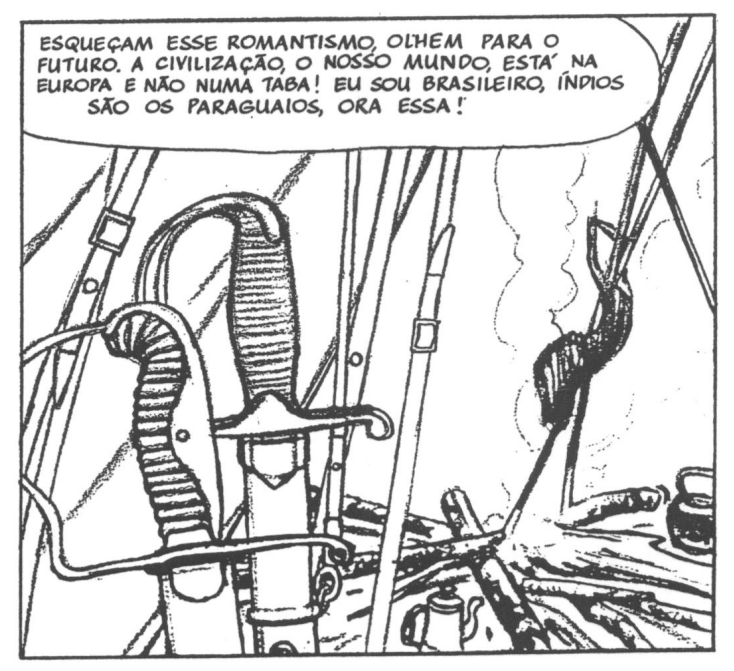

Fig. 12 (TORAL, 1997, p. 32) 
Fig. 13(TORAL, 1997, p. 8)
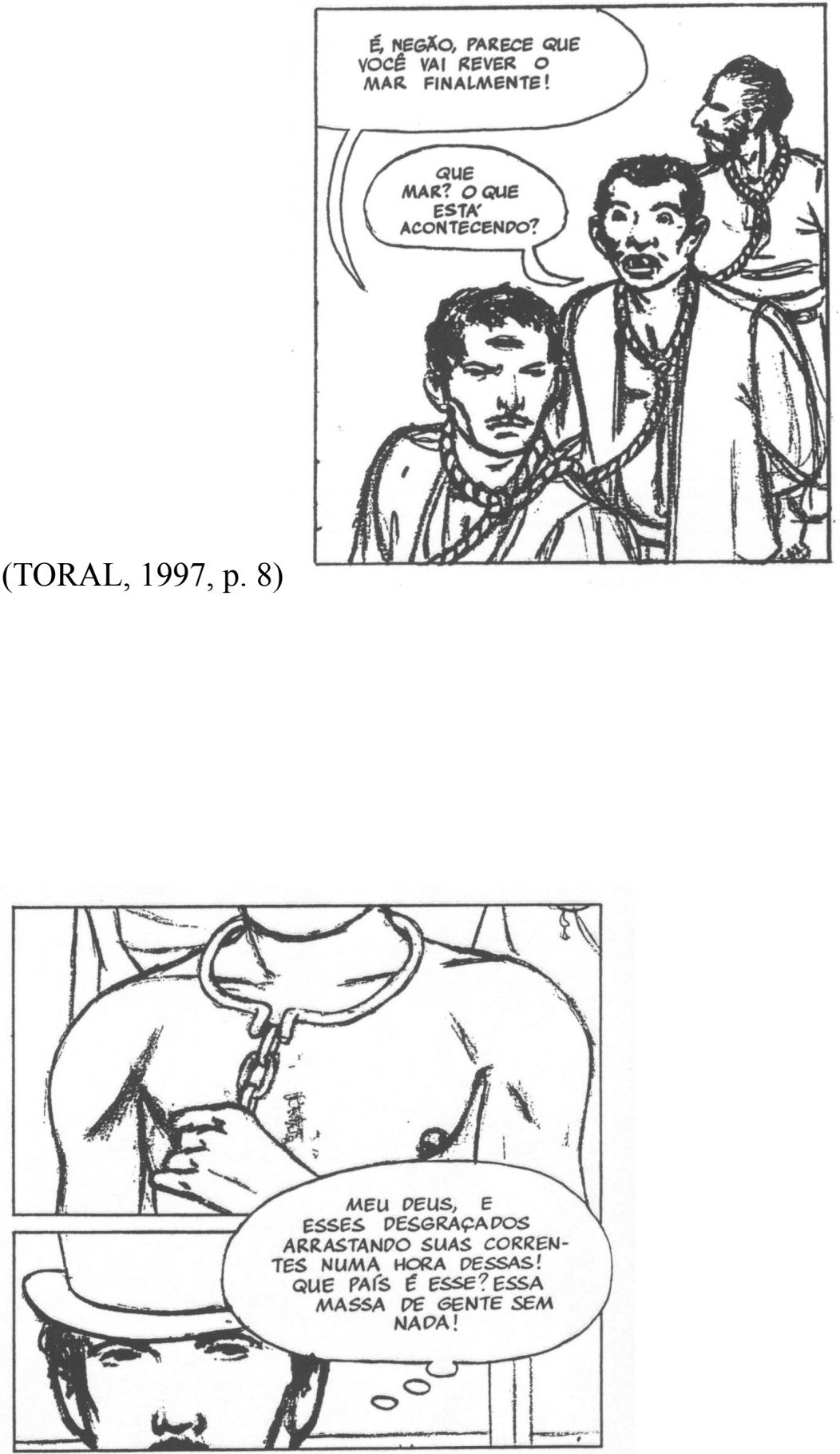

Fig. 14 (TORAL, 1997, p. 10)

Outro exemplo pertinente a essa relação da cultura material com a significação 
histórica, também referente à distinção de classes através da mesma, se dá nas diferenças dos armamentos [c. v., fig. 31 e 32]. Na primeira figura, os soldados rasos são mostrados estafados e sujos por conta do uso do armamento reservado para as linhas de frente do combate. $\mathrm{Na}$ segunda, o personagem Jorge, representante da elite, empunha gloriosamente seu revólver Colt fumegante em uma cena muito mais lisonjeira.

A significação visual é um elemento muito característico dos quadrinhos, que são das mais diversas maneiras caracterizados pela representação sintética. Devemos estar atentos para o fato de que muitas vezes o dado visual sintetiza um conteúdo vasto de significações, sejam elas pensadas pelo autor ou decorrentes de sua historicidade. Aqui tudo indica tratar-se dos dois, e a leitura de um simples quadro ou da relação entre dois quadros possibilita uma série de desdobramentos que interessam ao conhecimento histórico. 


\section{1. 4. 3. Símbolos visuais}

Há outras imagens significantes que, diferentemente do caso anterior, sobrepõem o significado à História. Atuam como símbolos visuais de certos conteúdos históricos e são, portanto, uma intervenção ativa do autor em atribuir significados à trama histórica narrada. Nem por isso merecem menos atenção. Apesar de ser um recurso linguístico próprio das artes visuais crucial para o desenvolvimento dos quadrinhos históricos, seu uso em termos de enunciação e recepção há muito vem se perdendo e por isso devemos redobrar a atenção para os mesmos quando da leitura dos quadrinhos.

Um exemplo desse recurso à simbolização visual da história encontra-se nas figuras 15 e 16. Nesse caso há a inserção de pássaros como pombos e o gavião que atuam como símbolos de momentos específicos da narrativa. O pombo, como símbolo de paz e de amor, marca um momento da trama contrastante à aparição do gavião, ave de rapina que simboliza a guerra e a dominação política. Essa simbologia é histórica num sentido diferente do caso anterior. Na evolução de tais símbolos, sua significação é particularmente acentuada no século XX, a exemplo da pomba imortalizada por Picasso ou da analogia na oposição política norteamericana nas questões militares que opõe os partidos de hawks and doves. Tais símbolos são sobrepostos à história como recursos narrativos com a mesma função de síntese icônica em sua representação. É, porém, uma forma de significação talvez mais atribuída à história que depreendida da mesma.

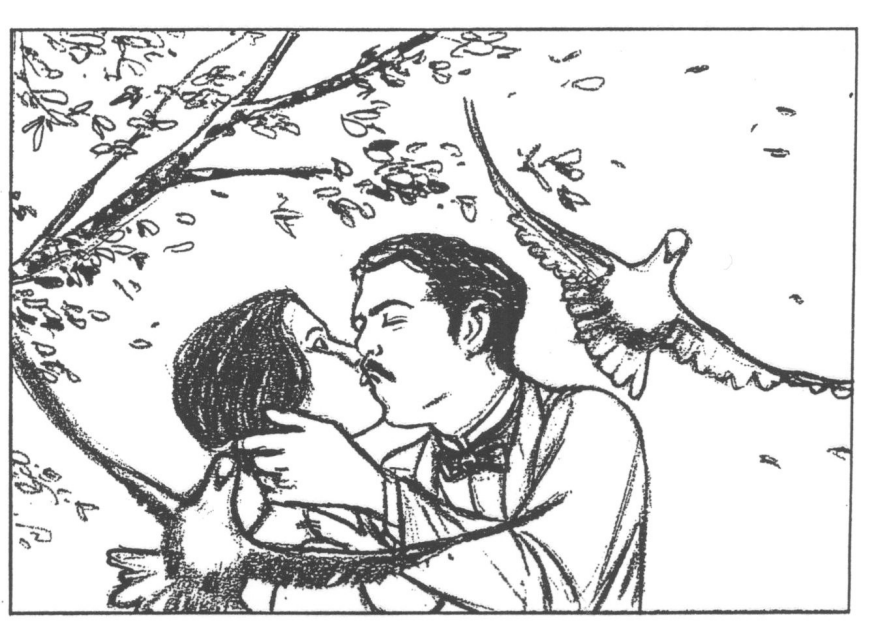

Fig. 15 (TORAL, 1997, p. 16)

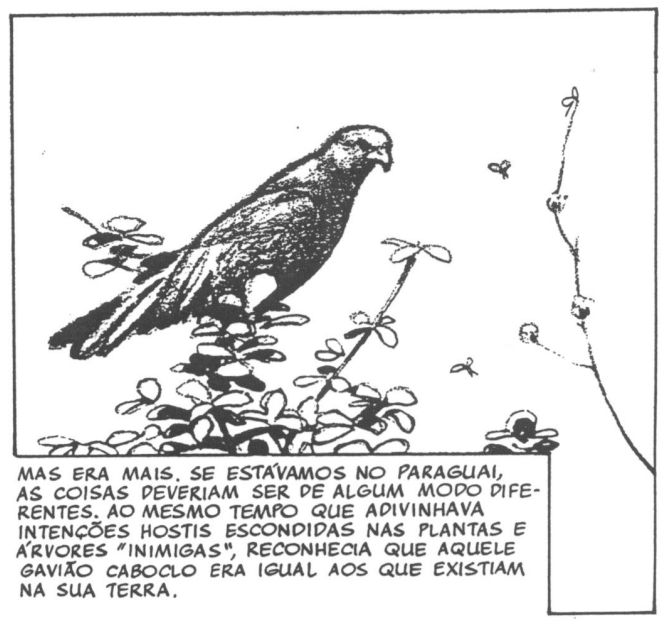

Fig. 16 (TORAL, 1997, p. 28) 


\section{1. 4. 4. Representação do monumento histórico}

É aqui que toma forma narrativa a crítica do documento como construto do passado com vistas à perpetuação memorialística, isto é, enquanto monumento. É o caso da recepção [fig. 17] e produção [fig. 18] da imprensa ilustrada da época como propaganda nacionalista em ambos os lados do conflito. Também é o da produção iconográfica mais propriamente como legado para a posteridade como registro visual, como no caso dos desenhos de campo de Cándido López [fíg. 19] ou as fotografias de Esteban Garcia [fig. 20]. Ou ainda como no plano aberto da figura 21 que representa a redação improvisada do periódico paraguaio, ou o plano fechado da figura 22 que representa um relatório policial paraguaio de espionagem sendo caligrafado à pena. Em outros casos, a representação crítica cede espaço para a utilização do monumento como marco cronológico na narrativa dos fatos históricos que situam o andamento da trama ficcional sobre o plano factual, como é o caso das figuras 23 e 24. Ainda há a utilização do mesmo recurso, como é o caso das figuras 25 e $\mathbf{2 6}$, em que os desdobramentos da opinião pública com relação à guerra são apresentados através da crítica exercida pela imprensa ilustrada acrescida do comentário sobre sua recepção.

Alguns desses aspectos, como a produção e recepção da imagem enquanto monumento, seu uso e função no contexto da cultura material, etc. podem se entrecruzar em casos como o das figuras $\mathbf{2 7}$ e $\mathbf{2 8}$, que se referem à produção e recepção de uma carte de visite, retrato fotográfico com vistas à memória afetiva privada; ou das figuras $\mathbf{9 ,} \mathbf{1 0}$ e 29, acerca da produção da pintura histórica de Victor Meirelles e sua recepção por parte do Estado brasileiro nas figura do imperador Dom Pedro II. Acrescentemos de passagem o fato de que nessas duas passagens houve uma reelaboração entre as versões da tese e do álbum. O quadro 28, que não constava na versão da tese, é sobreposto ao desfecho de um causo paralelo envolvendo as botas de Vitor Meireles [situado na mesma página do quadro da figura 29]. $\mathrm{Na}$ publicação do álbum também foi suprimida uma página inteira da versão original que trazia uma interessante sequência envolvendo o pintor, Silvino, Sebastião e um jabuti. Os dois soldados disputam a posse do animal por razões de necessidade alimentar e Meireles adquire o mesmo (em troca de suas botinas) em razão de seu interesse estético pelo mesmo, que segundo suas palavras possuía um "desenho tão geométrico, em tons de amarelo e café..." (TORAL, 1997, pg. 74). 


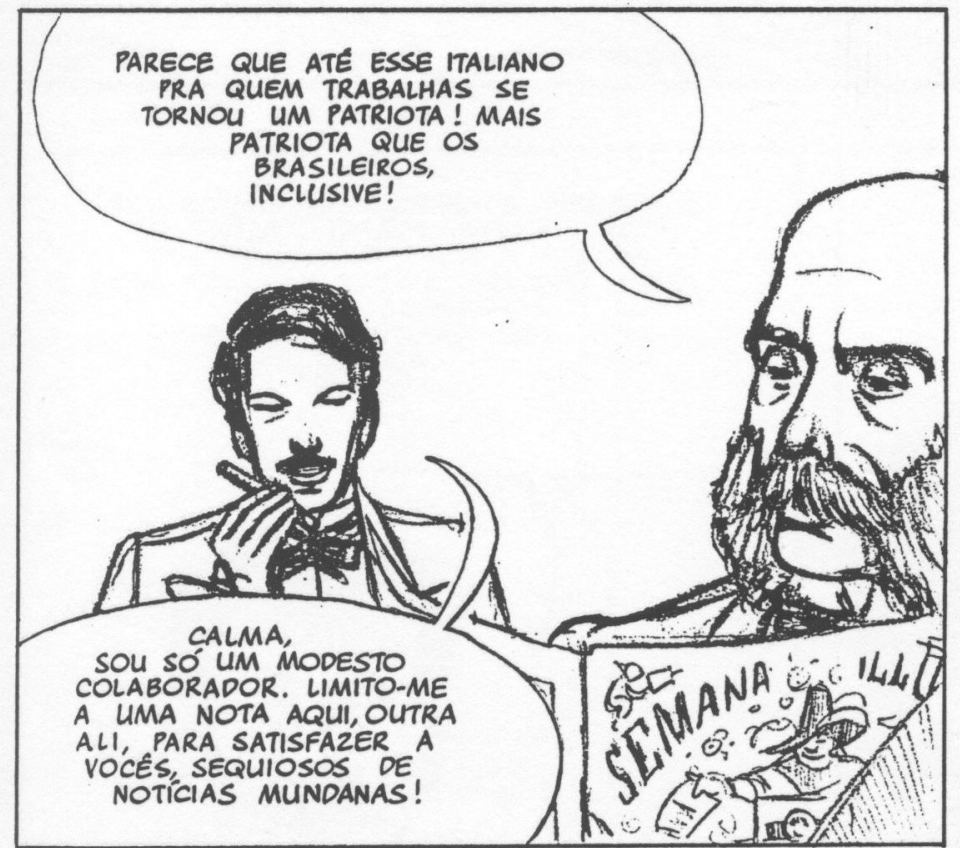

Fig. 17 (TORAL, 1997, p. 21)

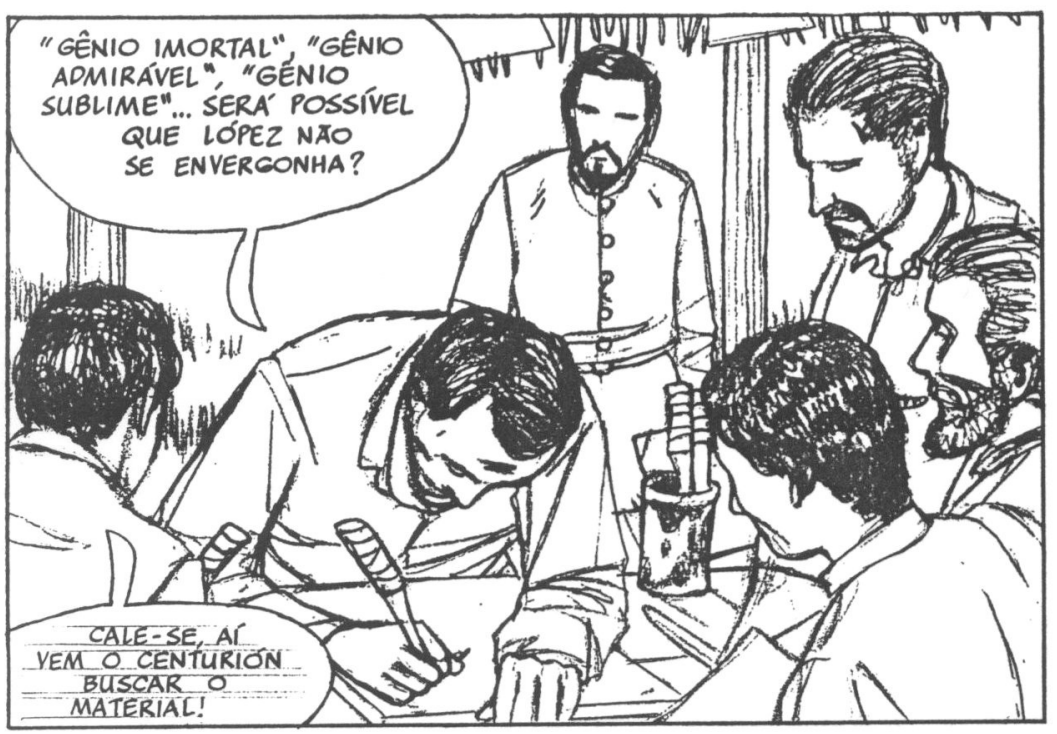

Fig. 18 (TORAL, 1997, p. 102) 

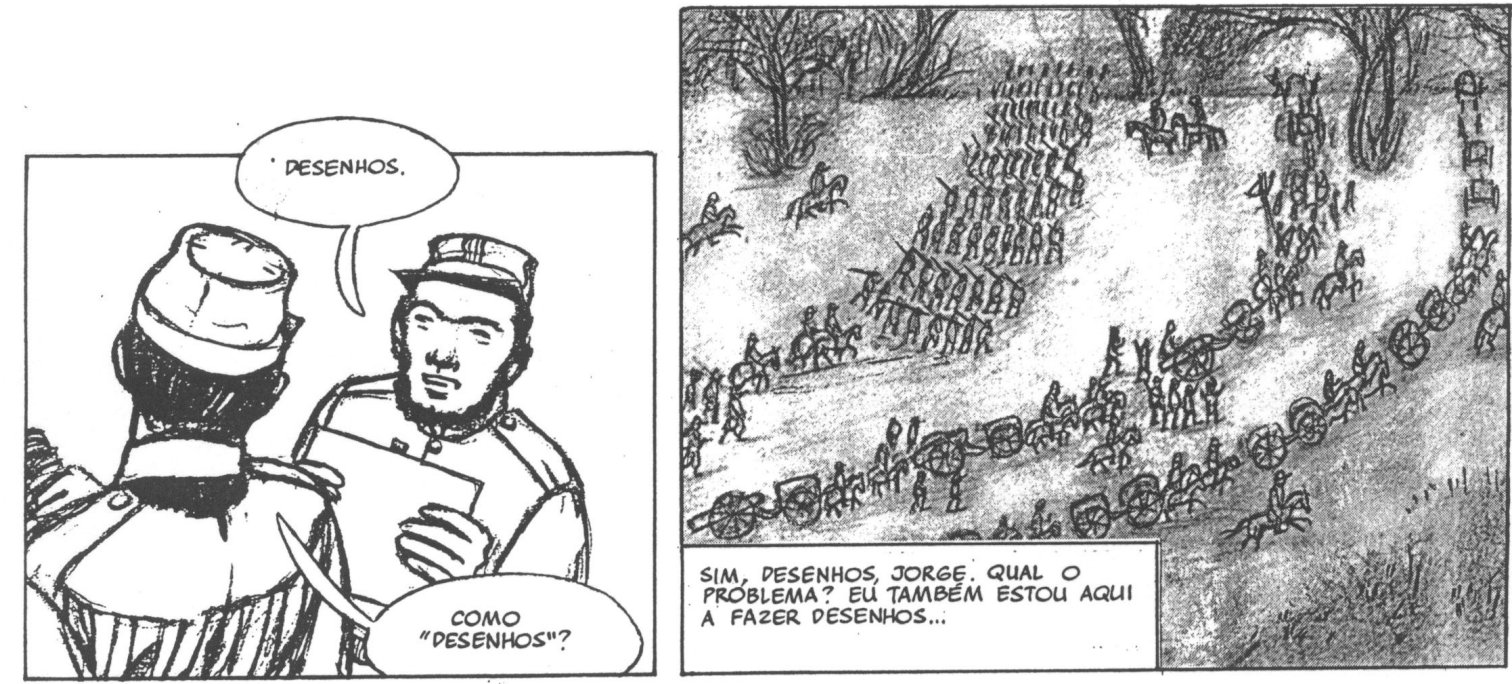

Fig. 19 (TORAL, 1997, p. 27)

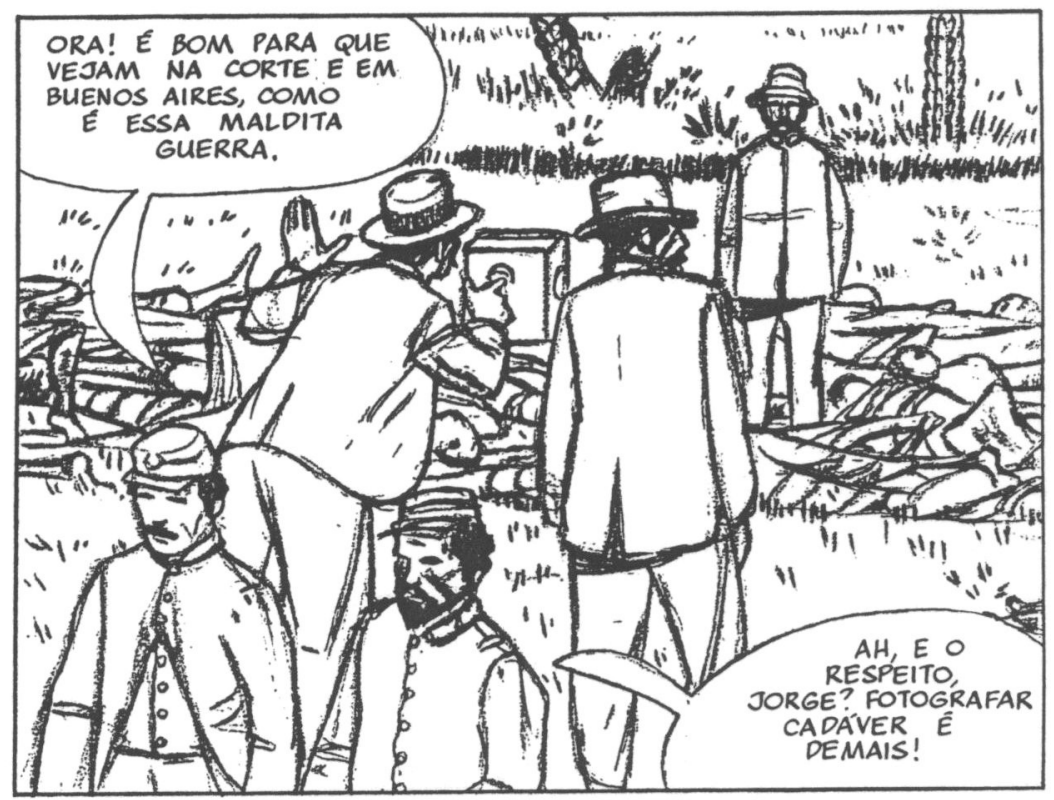

Fig. 20 (TORAL, 1997, p. 50) 


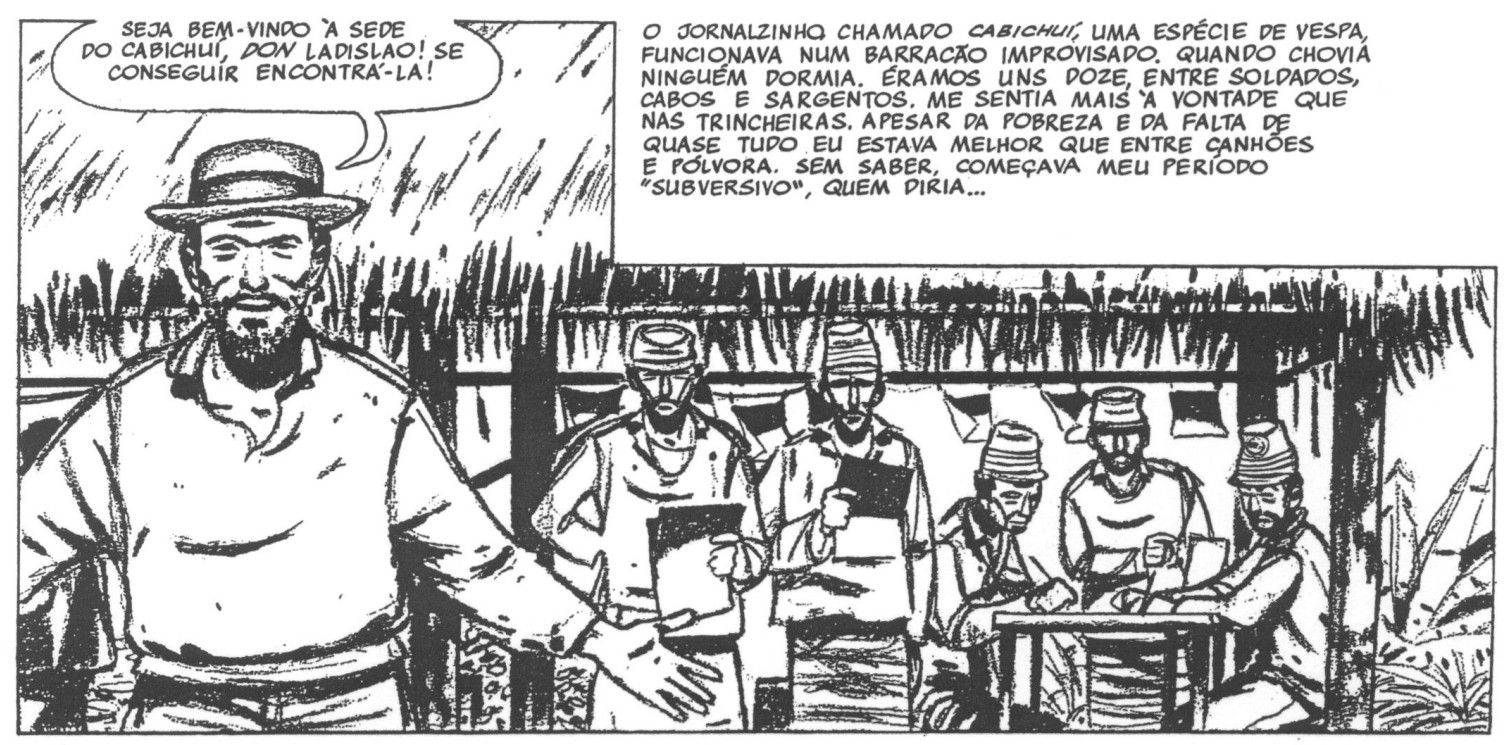

Fig. 21 (TORAL, 1997, p. 93)

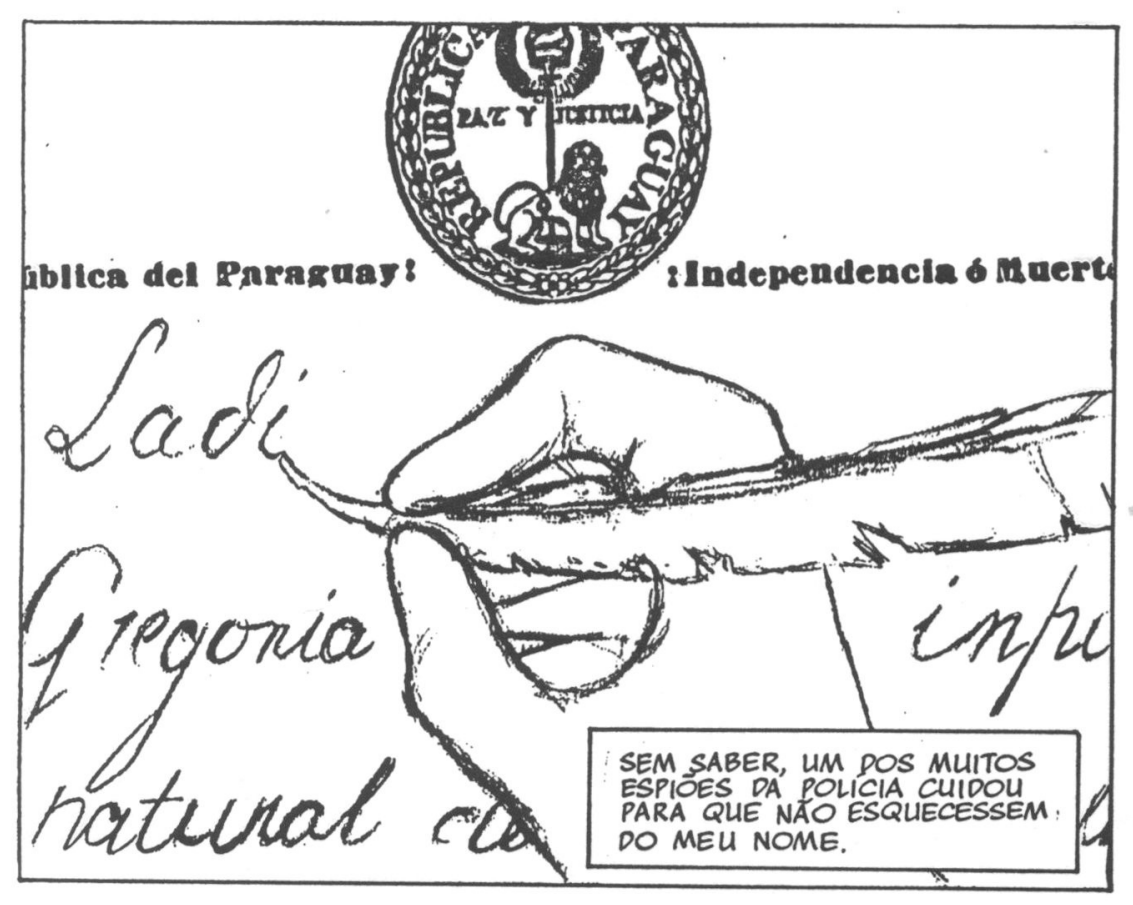

Fig. 22 (TORAL, 1997, p. 101) 


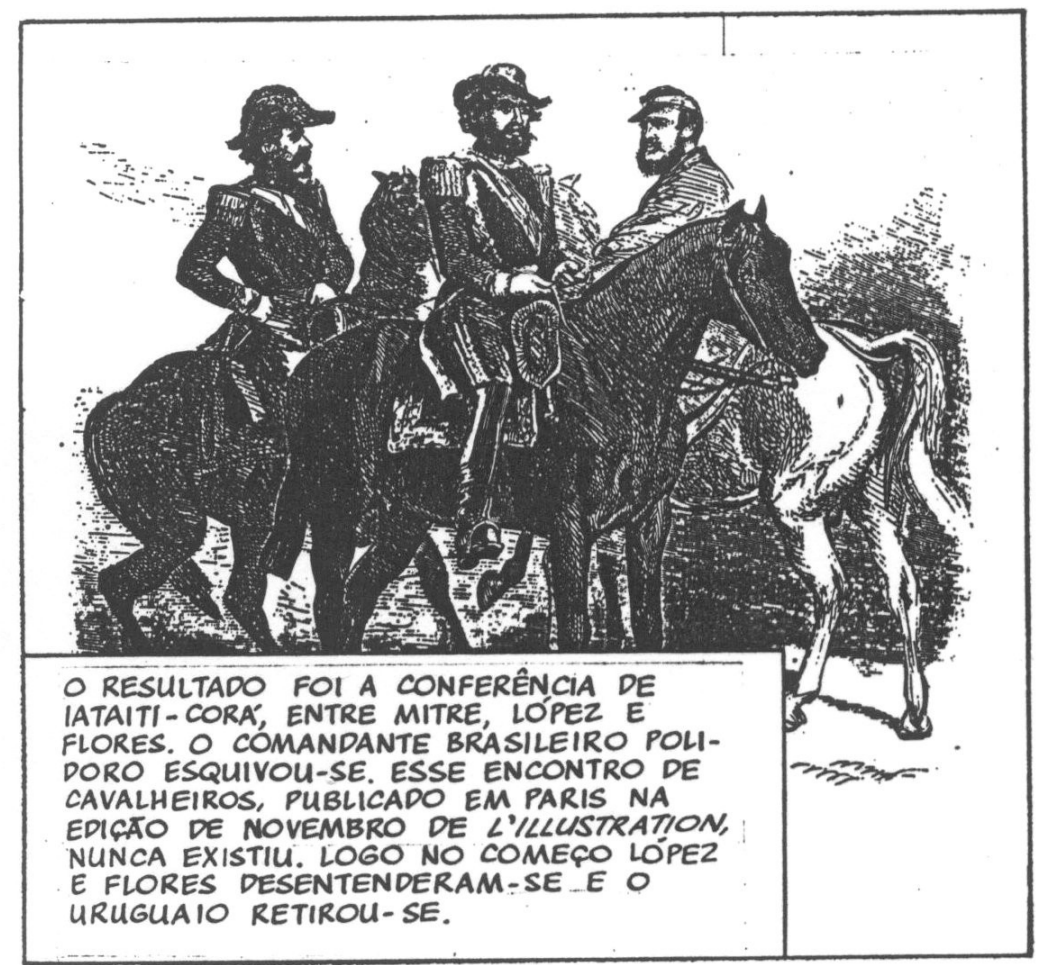

Fig. 23 (TORAL, 1997, pg. 51)

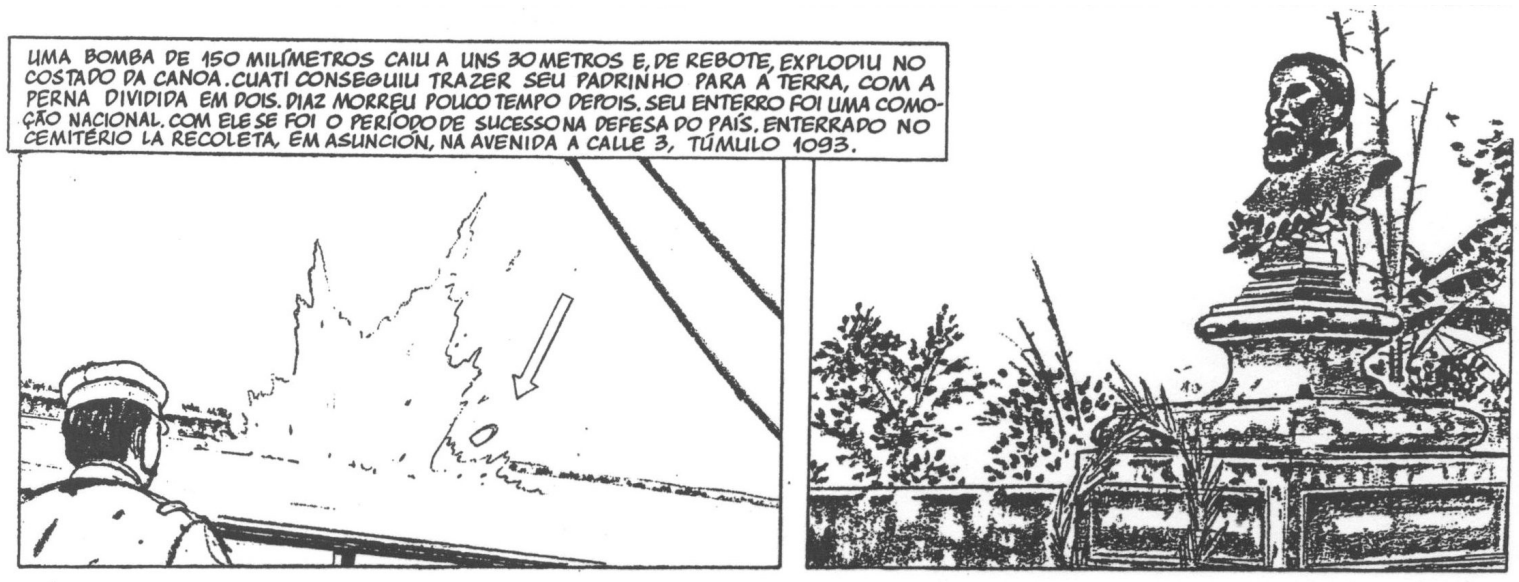

Fig. 24 (TORAL, 1997, p. 90) 


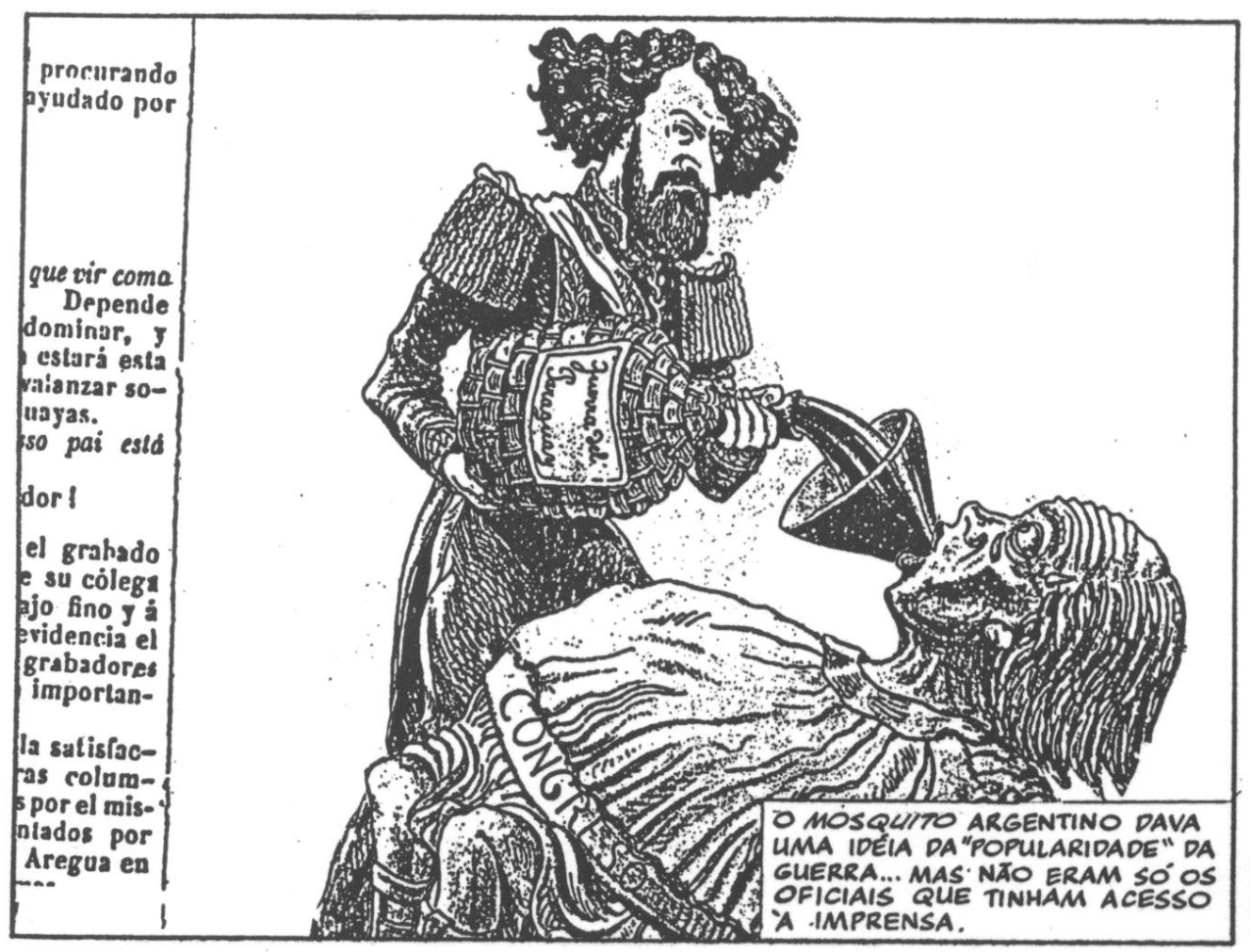

Fig. 25 (TORAL, 1997, p. 54)

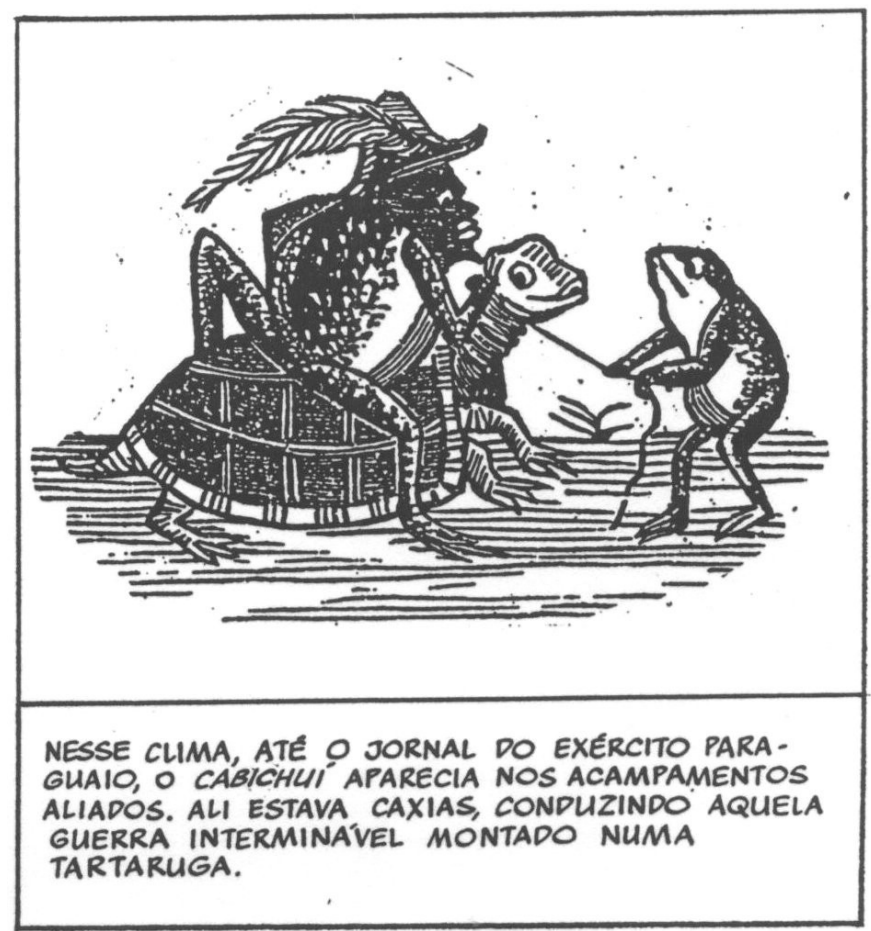

Fig. 26 (TORAL, 1997, p. 55) 


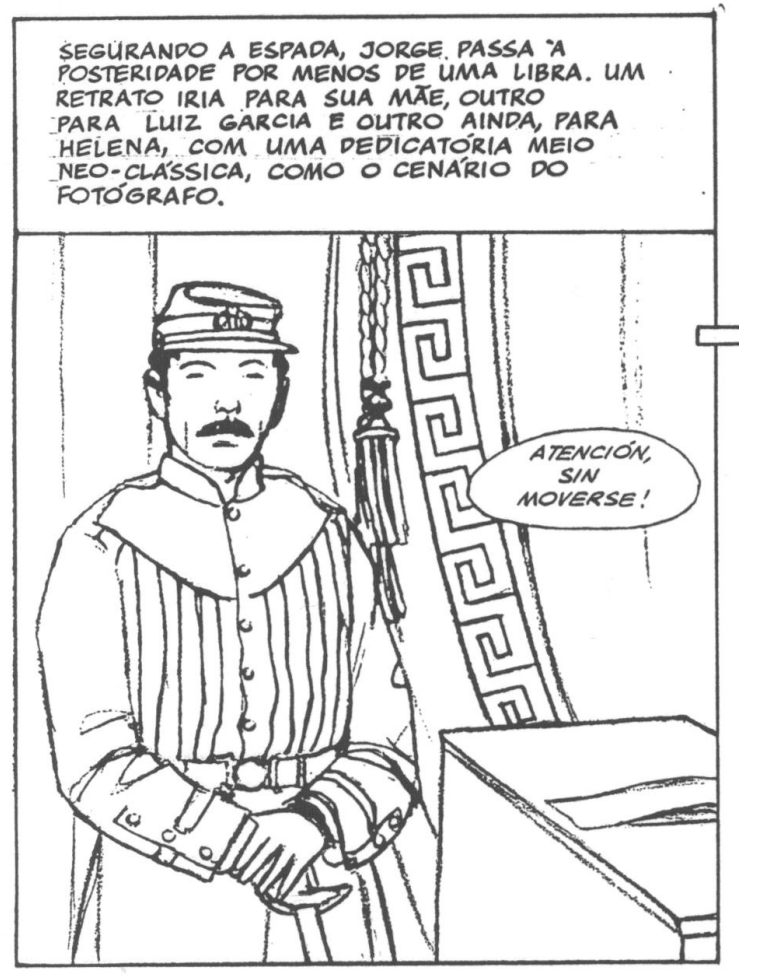

Fig. 27 (TORAL, 1997, p. 30)

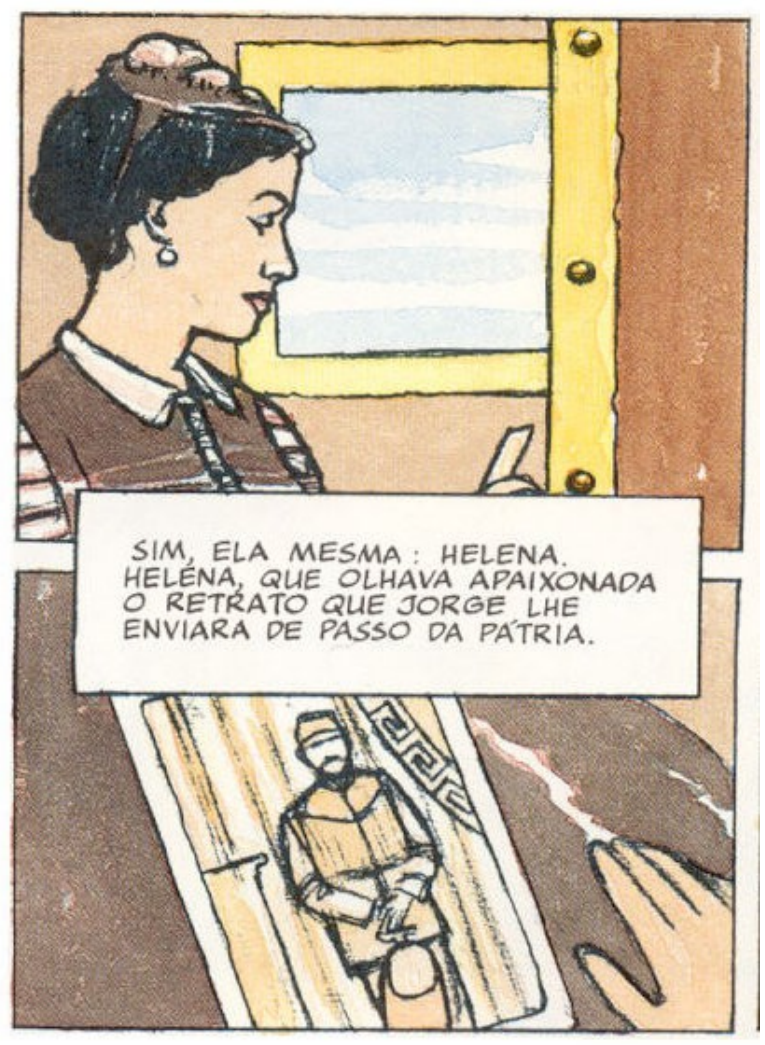

Fig. 28 (TORAL, 1999, p. 77) 


\subsubsection{Crítica do relato oral e metalinguagem histórica}

A narrativa de "Adeus, Chamigo (...)" possui diversas características historicizantes. Recorrendo assiduamente às caixas de texto que nos quadrinhos contém a chamada narrativa em off, a voz que nos fala através do enredo é a de um narrador contemporâneo, que conhece a história factual da guerra situando-nos em seus marcos cronológicos e nos indica que fala de um tempo bem posterior a ela, como, por exemplo, através da comparação: "Essa história é mesmo, como diria Gardel, uma caravana de recordações.” (TORAL, 1997, pg. 79). Podemos inferir também que se trata da voz do próprio autor em um comentário metalinguístico: "Sim, desenhos, Jorge. Qual o problema? Eu também estou aqui a fazer desenhos...” [fig. 19]. E por último, mas não menos importante, vemos na segunda parte da história que retrata a realidade paraguaia durante a guerra, um mecanismo narrativo bastante interessante do ponto de vista da epistemologia histórica. $\mathrm{O}$ autor passa a palavra para Ladislao, que conta sua experiência até ali. O relato do paraguaio é posto em dúvida quanto a sua veracidade histórica. Um episódio em que Ladislao teria supostamente travado contato com o imperador Dom Pedro II enquanto estivera preso é suspeitada primeiro por seu interlocutor, o personagem de Silvino ("Mas tu é besta mesmo! Conheceu o imperador? Conversa!", p. 82-5), e após a conclusão daquele testemunho oral continua sem convencer também o narrador que retoma a palavra (“Eu também não engoli a história do imperador!”, p. 109). Aqui o autor parece nos lembrar sutilmente da ambiguidade de sua tarefa simultânea de ficcionista e historiador, pois como narrador da história ele não é onisciente dos fatos vividos por seus personagens como habitualmente ocorre na prosa de ficção e por outro lado suspeita de um fato não comprovado ou pouco provável, como cabe a um historiador.

Trata-se do recurso à metalinguagem narrativa,.recorrente nos quadrinhos de Toral. A suspensão momentânea do enredo que dá lugar à reflexão sobre uma escrita ou ilustração é utilizada em prol da reflexão historiográfica - a escrita da história refletindo a si mesma, ou da reflexão acerca da linguagem quadrinística em si. Ou imbricadas, como no conto " $O$ Tradutor", publicado na coletânea "Curtas e Escabrosas" (TORAL, 2011, p. 13). Sobre o mar visto da praia, uma caixa de dialogo sugere: “Aqui, leitor, o tempo voa. Veja só: do quadrinho da página anterior para este se passaram 33 anos. Você já viu o tempo passar assim tão rápido? Não? Olha só: é o tempo que voa nas ondas do mar, que vem e vão sem parar”. 


\section{1. 4. 6. Representação do imaginário}

Dentre as representações de Toral para os usos possíveis daquelas imagens no seu contexto, entrementes, o mais criativo e audacioso parece ser aquele que representa seus possíveis efeitos subjetivos no próprio imaginário da época numa espécie de quadrinização da história das mentalidades. É o caso de um quadro que representa a imaginação paranoica de Ladislao que teme o inimigo brasileiro na forma em que eram representados pela propaganda racista paraguaia, ou seja, na figura de macacos [fíg. 33]. O mesmo recurso à representação da subjetividade se dá para representar outra relação de alteridade onde predominam a hostilidade e o medo, só que desta vez não entre brasileiros e paraguaios, mas entre os próprios brasileiros. É o caso da relação entre gaúchos e baianos no interior dos exércitos aliados, representada em um sonho de Silvino [fíg. 34]. Nos dois casos a imagem mental que carrega um conteúdo de terror psicológico é representado quadrinisticamente por silhuetas tenebrosas.

O primeiro caso nos é especialmente interessante por se tratar da ilustração de uma imagem mental que seria hipoteticamente influenciada pela propaganda de guerra da imprensa ilustrada paraguaia da época. Trata-se, portanto, de uma representação narrativa por meio dos quadrinhos de uma hipótese científica proveniente da assim chamada história das mentalidades e de sua preocupação com o imaginário social enquanto objeto da historiografia, a qual Toral também faz referência explicita na introdução de sua tese. 


\subsubsection{O quadrinho Histórico em sua dialética: monumento histórico - documento histórico - monumento historiográfico}

Finalmente, pinçamos um exemplo da relação entre o monumento produzido na guerra, que se transforma em documento na pesquisa iconográfica, para então tomar novamente a forma de um monumento em quadrinhos. $\mathrm{O}$ quadro da figura 35 é nitidamente inspirado por uma fotografia tomada naquele acampamento de Tuiuti por ele representado [fig. 36].

À primeira vista, destaca-se a verossimilhança visual com a cena retratada, com todos seus personagens e objetos. A recriação do documento fotográfico no enredo quadrinístico vai, porém, muito além. Primeiro, podemos observar como mudam as fisionomias dos combatentes em situações diferentes. Na fotografia vemo-los austeros, talvez por conta do próprio processo envolvido, cuja técnica requeria a imobilidade dos retratados e cujas identidades sociais dos combatentes lhes sugeria tal pose e expressão. No quadrinho não os vemos sendo fotografados, mas sim gozando do momento de refeição, descanso e confraternização em que possivelmente se encontravam aqueles combatentes antes de posarem para a foto. Ao pesquisar tais documentos iconográficos Toral teve de passar pelos meandros de sua exegese. Aqui a recriação de uma situação através de documentos específicos sobre a mesma, no caso uma situação corriqueira relativa ao cotidiano da guerra, também passa pela crítica documental - só que de outra forma: narrativa ao invés de analítica. Vemos o confronto de duas formas de representação que possuem cargas diferentes de realismo por conta não apenas de se tratar de representação imediata ou historicamente mediada mas também por conta das peculiaridades dos próprios processos representacionais envolvidos. A foto em questão é posada mas pretendia-se testemunho ocular do acampamento de guerra em seu cotidiano. Em “Adiós Xamigo (...)”, Toral perfaz o caminho de volta da História e, através de seus quadrinhos, dá uma nova vida à mesma. 


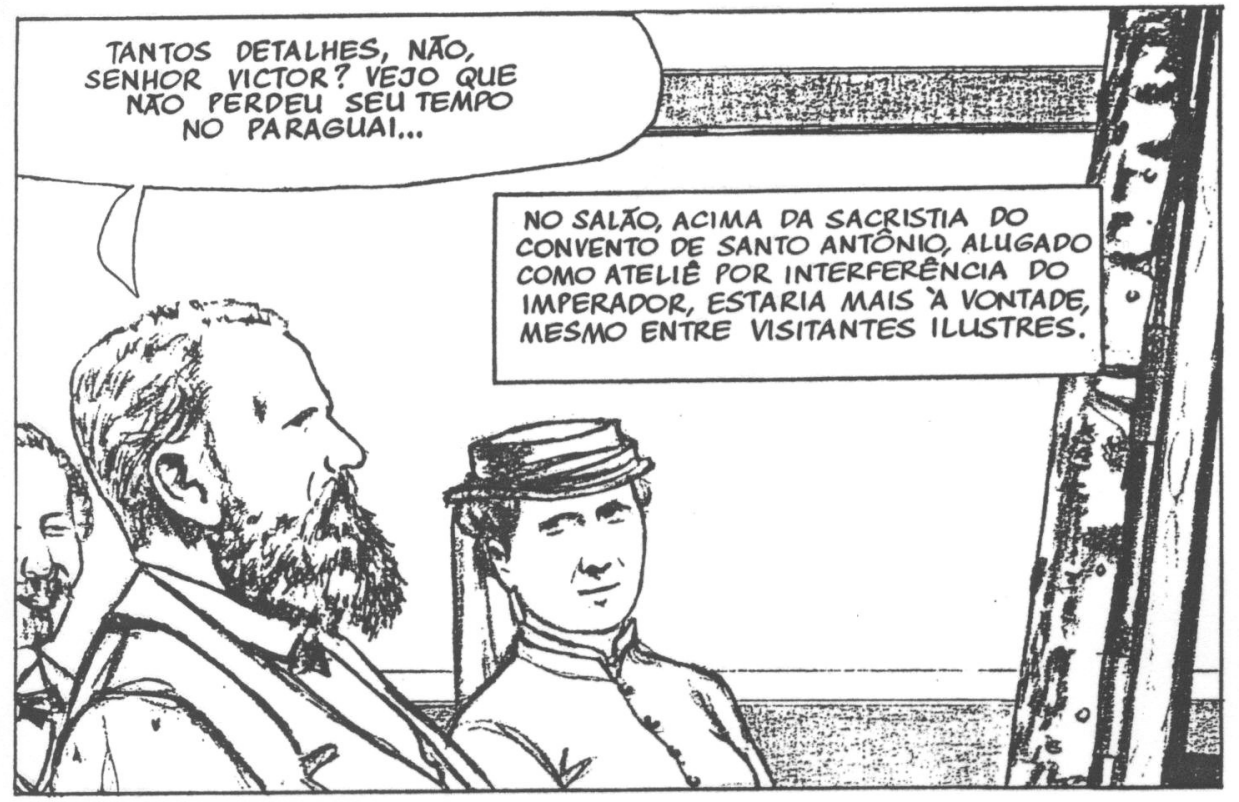

Fig. 29 (TORAL, 1997, p. 75)

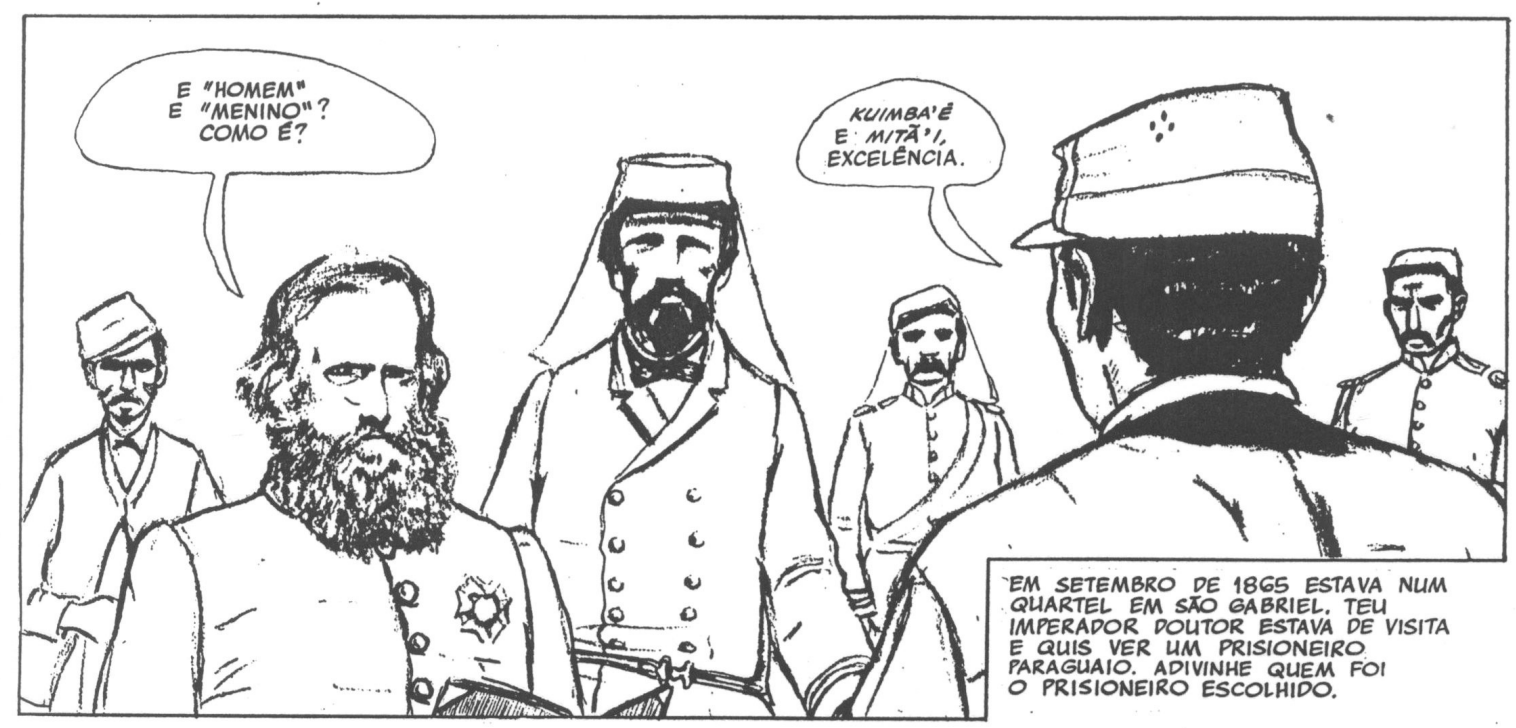

Fig. 30 (TORAL, 1997, p. 86) 


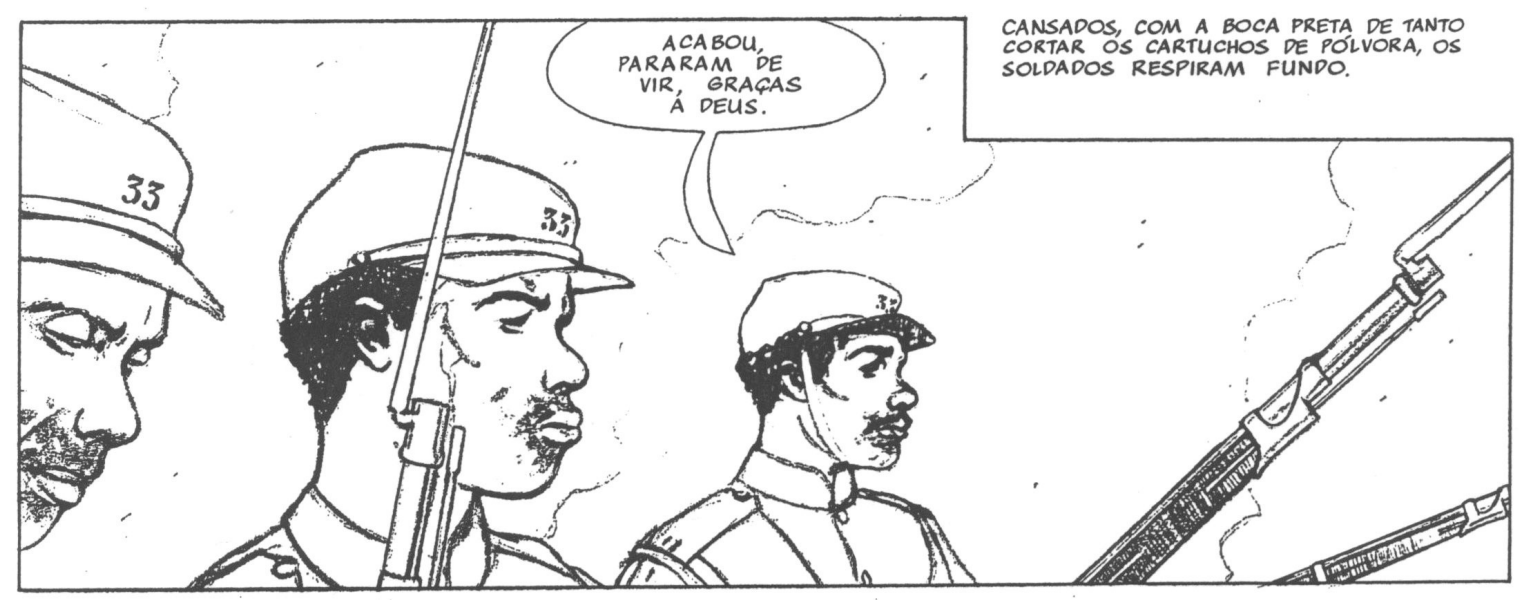

Fig. 31 (TORAL, 1997, p. 45)

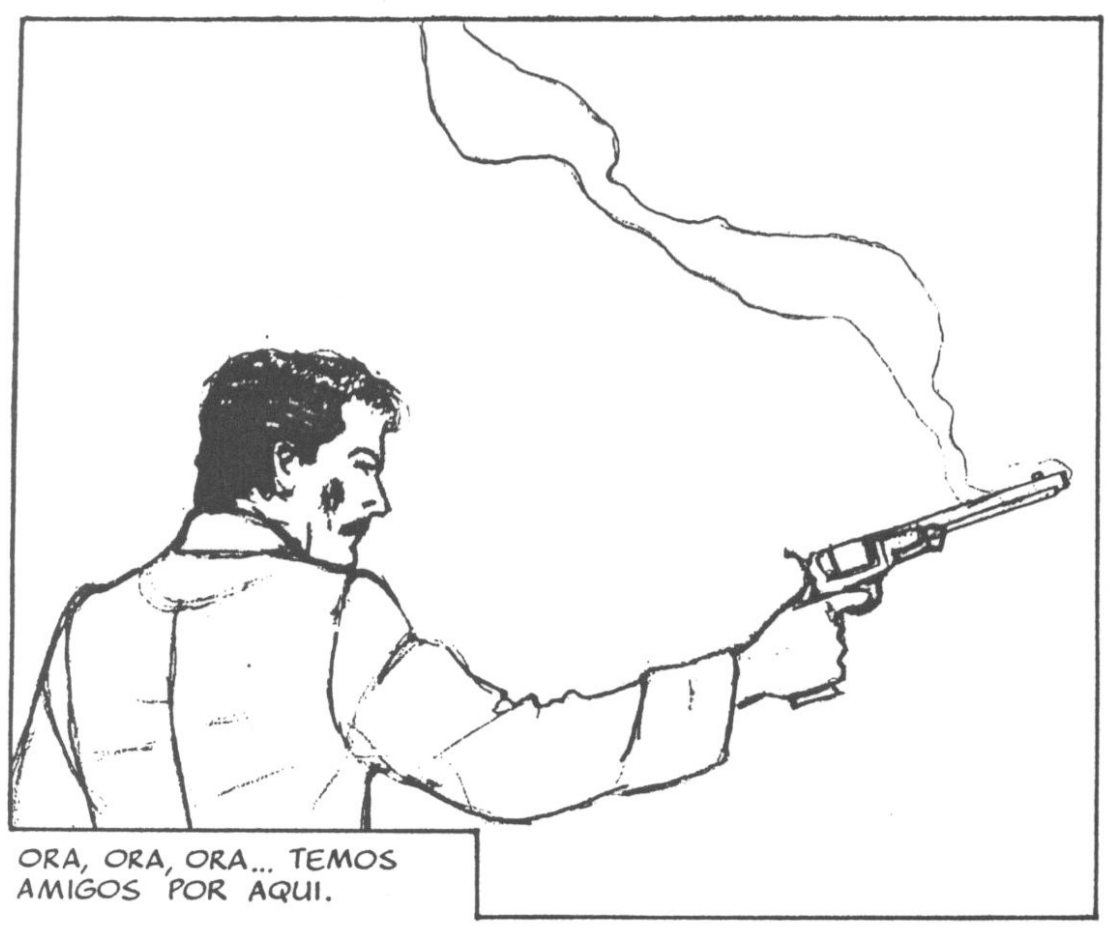

Fig. 32 (TORAL, 1997, p. 114) 
82

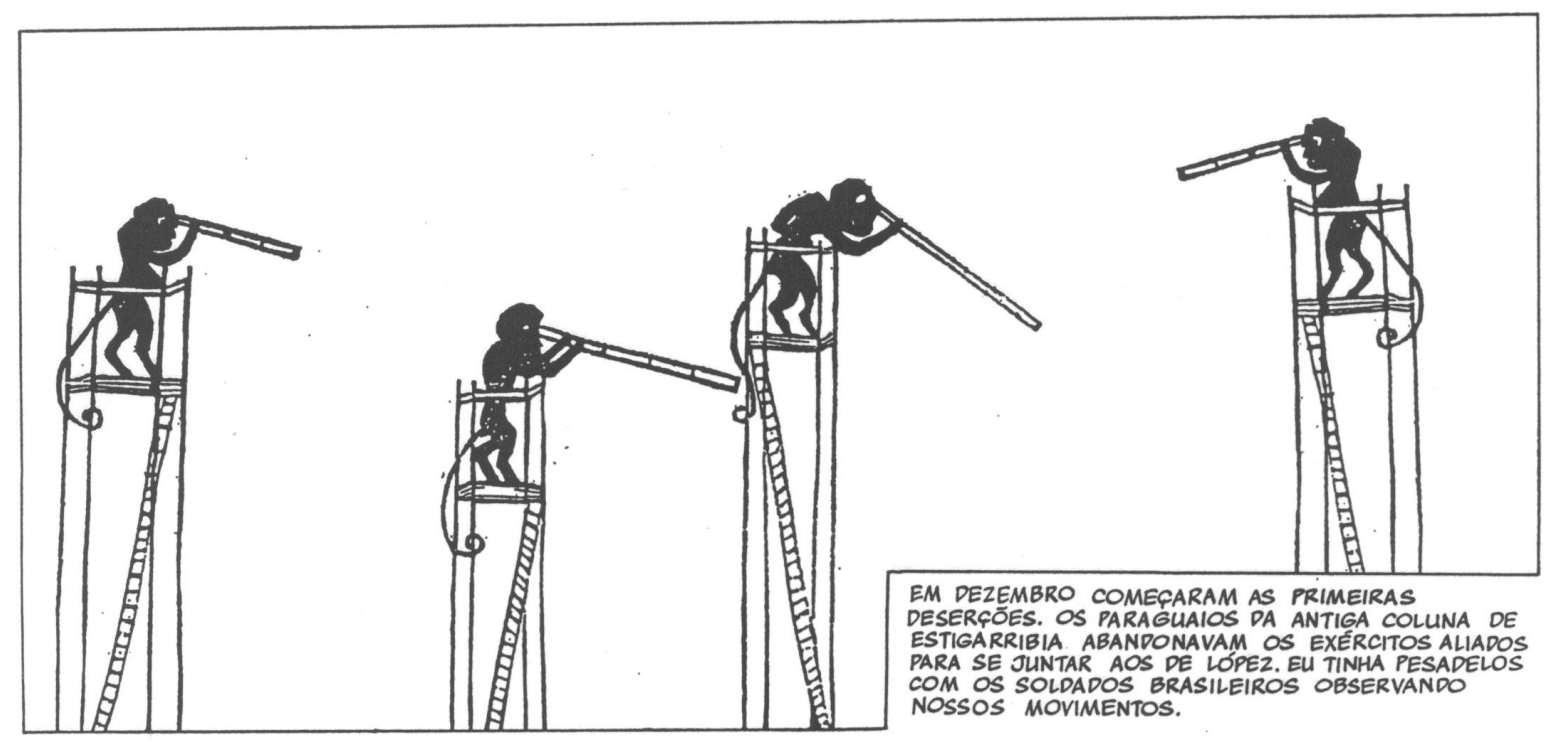

Fig. 33 (TORAL, 1997, p. 87)

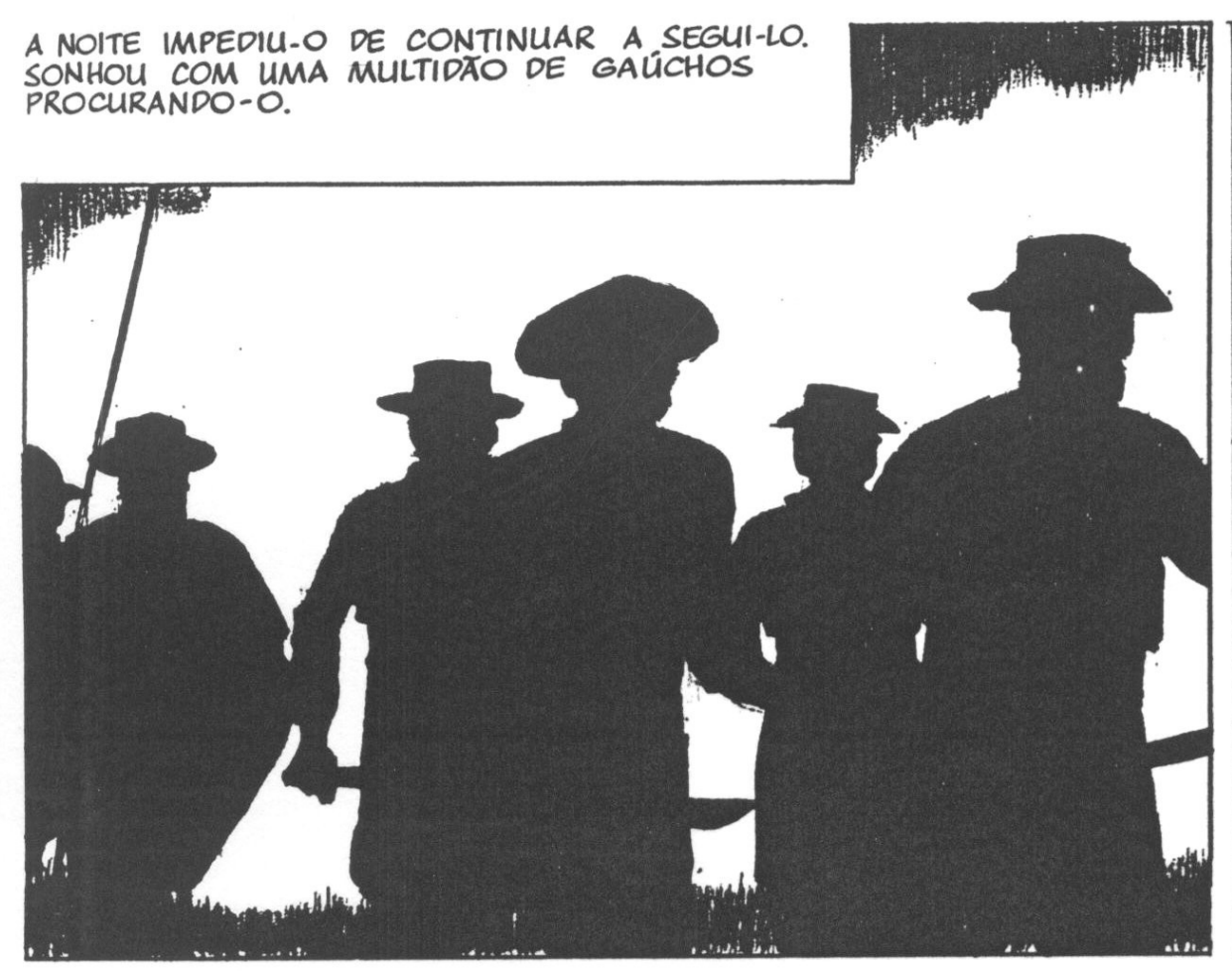

Fig. 34 (TORAL, 1997, p. 78) 


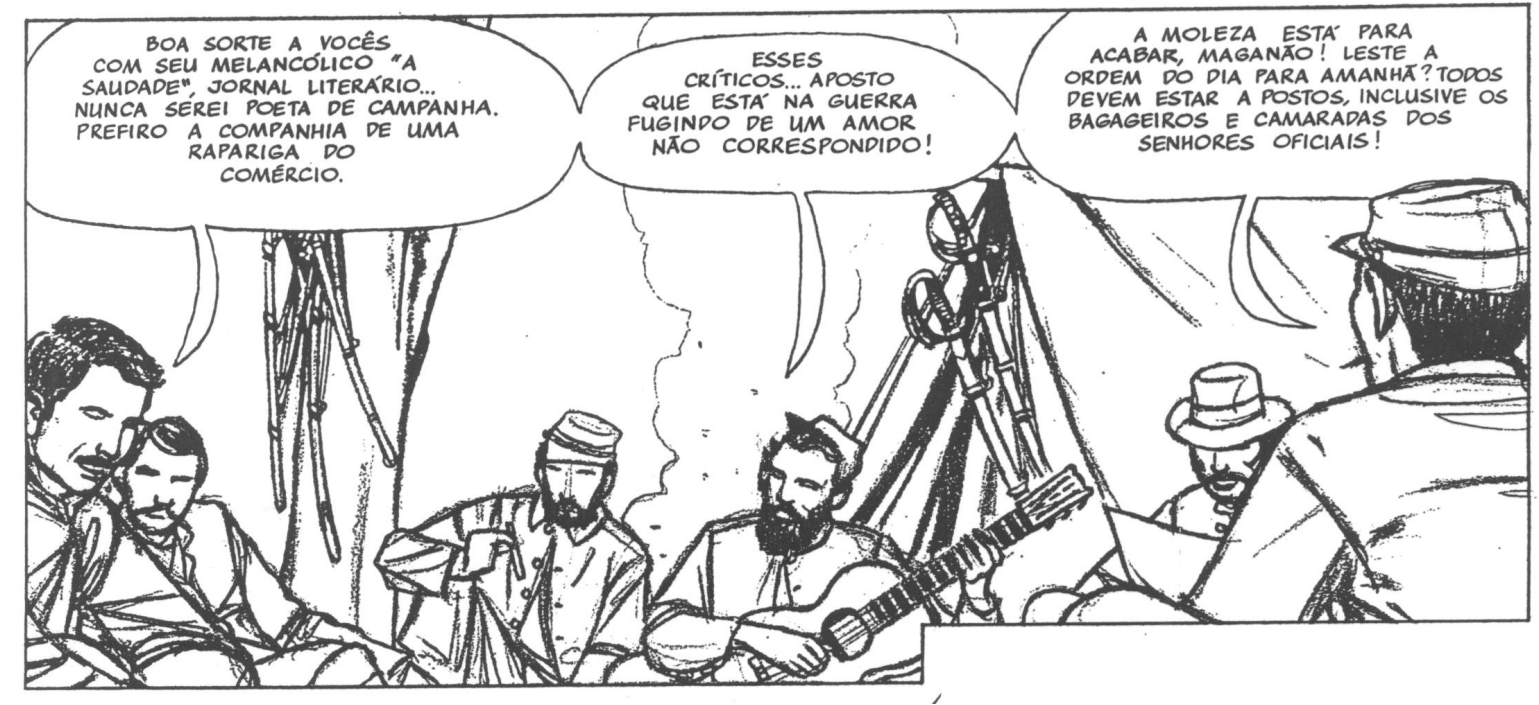

Fig. 35 (TORAL, 1997, pg. 32)

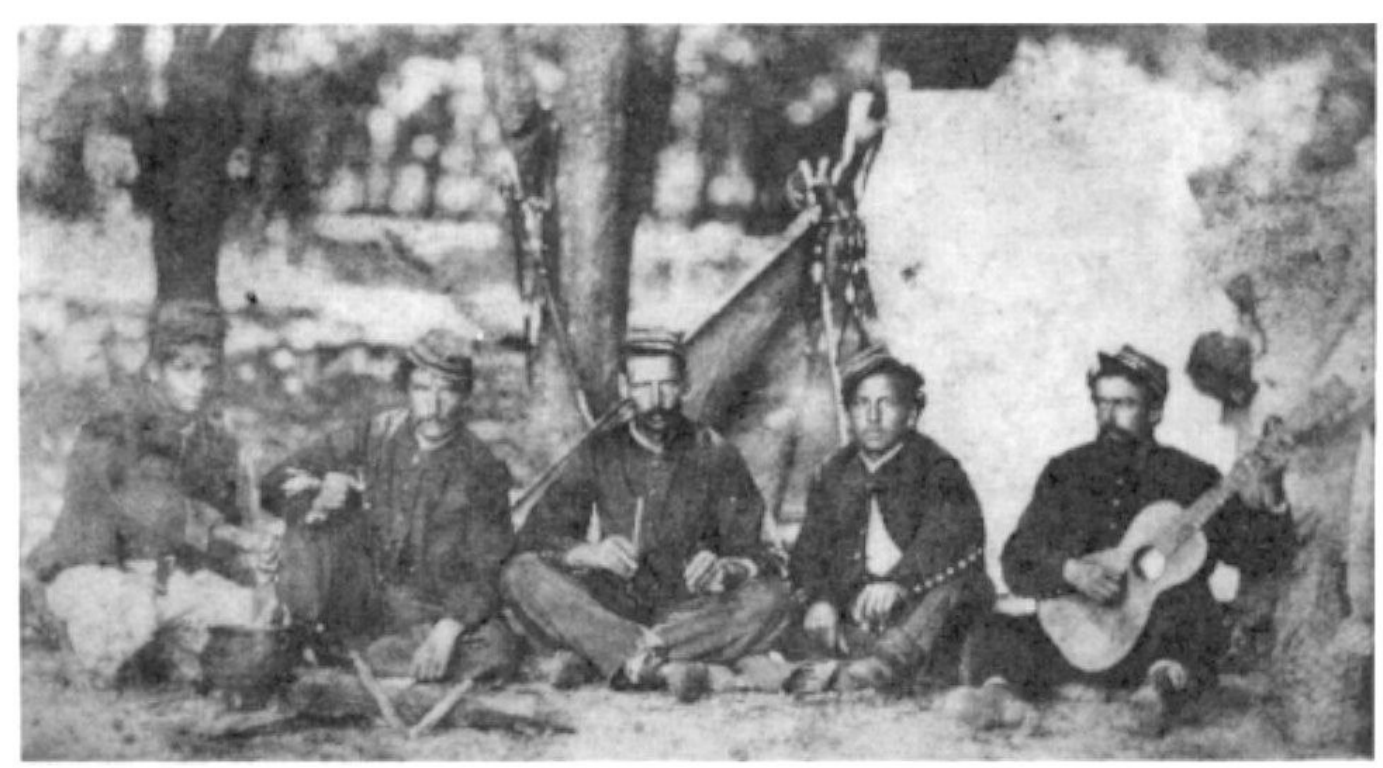

4. Oficiais argentinos em Tuiuti, 1867.

Fig. 36 (TORAL, 1999, p. 122) 


\subsection{Comunicação cômica do conhecimento histórico}

Outro tipo de experiência de quadrinho didático-histórico, diferente daquela de André Toral, é a da coleção Redescobrindo o Brasil, de meados dos anos oitenta, e dos quadrinhos do cartunista Spacca, especialmente sua obra D. João Carioca, que em certo sentido consiste em um aperfeiçoamento recente da experiência daquela coleção. Suas diferenças com relação à obra de Toral se dão principalmente na relação de trabalho entre o conhecimento histórico e sua formulação quadrinística, cujas tarefas são divididas pela especialização acadêmica e artística em um sistema de colaboração bilateral em que historiadores e quadrinistas são co-autores das obras em questão; e no âmbito da forma quadrinística propriamente dita, difere daquele pela escolha de um estilo cômico de representação histórica. A análise dessas obras será realizada em dois momentos: o primeiro será dedicado à coleção Redescobrindo o Brasil e se refere, portanto, ao período dos anos oitenta; o segundo avança até a primeira década do século XXI para se debruçar sobre a obra da historiadora Lilia Schwarcz em parceria com o quadrinista Spacca. 


\subsubsection{A coleção Redescobrindo o Brasil como cartunismo histórico}

A coleção Redescobrindo o Brasil é a mais representativa experiência que comunica conhecimentos históricos por meio da linguagem dos quadrinhos nos anos oitenta. Lançada pela editora Brasiliense - na época bastante dedicada à publicação de livros paradidáticos e de divulgação científica tais como nas coleções Tudo é História e Primeiros Passos -, sua proposta consiste em uma mescla de textos de síntese histórica comprometidos com o conhecimento histórico (cujo recorte temático é especialmente preocupado com o currículo escolar) escritos por historiadores de formação acadêmica - Lilia Moritz Schwarcz e Júlio José Chiavenatto - e ilustrados por dois dos cartunistas mais proeminentes da época - Angeli e Miguel Paiva. São três livros que cobrem períodos específicos da História do Brasil. Segundo a numeração dos volumes da coleção, que não diz respeito à cronologia histórica dos mesmos, são eles: o volume um, Da Colônia ao Império: um Brasil para inglês ver, de Paiva e Schwarcz; o volume dois, Cai o Império! República vou ver!, de Angeli e Schwarcz; e o volume três, Olha lá o Brasil! E finalmente Portugal nos descobriu..., de Paiva e Chiavenatto.

Os textos caracterizam-se por uma síntese narrativa de fatos e explicações históricas bastante próximas daquelas presentes em livros didáticos convencionais voltados para $\mathrm{o}$ público escolar, porém, com a diferença crucial de que seu tom é, como já mencionamos, humorístico. Com essa diferença há uma radical inversão de expectativas de gênero no que se refere ao texto didático tradicional que é convencionalmente sério, isto é, muito raramente incorre na liberdade poética de ordem cômica. O tom humorístico dos textos da coleção Redescobrindo o Brasil, entretanto, não desqualifica seus livros do ponto de vista do gênero do texto didático, pois a expectativa convencional de seriedade não é prerrogativa inescapável para a comunicação do conhecimento histórico, sendo essa última a principal expectativa funcional do gênero em questão.

Se por um lado a solenidade discursiva é regra do texto didático lido nas escolas, por outro lado a mesma regra não possui a mesma incidência no discurso oral do professor em sala de aula. A título de comparação podemos traçar a analogia de que muitas aulas expositivas, especialmente em cursos pré-vestibulares, adquirem a forma de uma stand up 
comedy, um gênero humorístico de oratória cada vez mais popular (a popularização internacional do gênero adquiriu grande impulso a partir dos anos noventa do século XX através do seriado televisivo norte-americano Seinfield). É muito comum que em seu discurso os professores de história se valham do humor para narrar ou explicar seus conteúdos sem que isso constitua uma deturpação da cientificidade disciplinar dos mesmos. Nesse caso o humor é considerado inclusive mais "didático" naquele sentido rasteiro do uso corrente da palavra, ou seja, trata-se de um elemento facilitador da comunicação do conhecimento histórico por envolvê-lo em uma fruição lúdica e, portanto, supostamente mais interessante.

Os desenhos caracterizam-se pela forma caricatural de representação. Há na relação autoral de produção dos livros uma proeminência da ilustração, isto é, os desenhos referem-se aos textos previamente compostos. Por essa razão o resultado é uma hibridização de linguagens em que a história em quadrinhos, entendida como uma linguagem em que texto verbal e visual são integrados em uma narrativa sequencial, faz aparições pontuais mas não conforma a totalidade de suas narrativas. O fio condutor das mesmas é em grande medida o texto verbal de caráter informativo em verve cômica.

Dentre os três livros, a forma mais interessante de condução dessa narrativa - que em todos os volumes é fragmentada em eixos temáticos - é, provavelmente, a do livro Cai o Império (...). Nele são utilizados quatro personagens estereotípicos - um esquerdista, um direitista, um jovem negro e uma jovem hippie - que são conduzidos pelos episódios do livro observando e criticando a história narrada. Os personagens, através de sua estereotipia, representam pontos de vista partidários de certa forma representativos de seus grupos sociais. Claro que nesse processo representacional por meio do estereótipo, assim como muitas vezes se dá na representação caricatural, o que ocorre é uma simplificação inevitavelmente reducionista da realidade representada.

A questão da simplificação surge, para além da forma quadrinística, no âmbito da formatação didática como um todo. Há na coleção Redescobrindo o Brasil uma visível intencionalidade por partes dos autores em adaptar certos conhecimentos históricos - no caso, aqueles padronizados pelo currículo escolar aliados aos seus desenvolvimentos científicos à época mais recentes - para o público escolar. Esse sentido de "adaptação de conteúdos" é muitas vezes lembrado como sendo o "procedimento didático" por excelência, quando na 
verdade trata-se de uma contingência de certas formatações didáticas para atender às necessidades de públicos específicos. Rüsen (2007, p. 89) se refere a essa mentalidade como "didática da cópia". Quanto a essa idéia reduzida de didática, o autor afirma que é "reflexo de uma concepção estreita de ciência", mas atribui-lhe ironicamente a vantagem da "consciência das simplificações de linguagem".

A escolha da comédia e da caricatura, por fim, não serve apenas para conferir ludicidade à fruição do conhecimento histórico. Serve antes disso para dar forma a um viés crítico do conhecimento histórico. O tratamento predominantemente irônico e sarcástico da matéria histórica presente nessa coleção, principalmente com relação à história política brasileira, é particularmente condizente com uma tendência da historiografia do período de abertura política pós-ditatorial comumente qualificada de revisionista por empreender com freqüência a contestação dos cânones da história oficial tão caros ao regime ditatorial civilmilitar brasileiro. O caso de Chiavenatto é exemplar, pois o historiador é lembrado particularmente por seu trabalho de "reescrita" da história da Guerra do Paraguai com grande simpatia pelo lado derrotado, o lado paraguaio, e, portanto, avesso ao militarismo nacionalista brasileiro. O viés desse historiador foi alvo de muitas críticas historiográficas posteriores por centrar sua revisão em questões de ordem mais política que de ordem científica, isto é, uma revisão empírica da historiografia oficial.

Se no âmbito do debate científico acadêmico esse revisionismo é, no mínimo, contestável em suas ênfases, do ponto de vista da divulgação popular do conhecimento histórico a ênfase crítica não é necessariamente deturpadora, contribuindo em grande medida para a reorientação política da consciência histórica nacional. Esse é, talvez, o maior mérito da coleção Redescobrindo o Brasil. Trataremos a seguir daquele que julgamos ser o recurso de linguagem mais original utilizado nesta coleção para dar forma ao conhecimento histórico: a alegoria. 


\subsubsection{Alegorias na coleção Redescobrindo o Brasil}

O uso de personagens alegóricos, que simbolizam idéias, instituições, etc. é um recurso dos mais recorrentes na caricatura política do século XIX. Trabalhamos aqui com uma noção genérica de alegoria. Benjamin (1985), em sua tese de livre-docência intitulada Origem do drama barroco alemão (e curiosamente recusada pela Universidade de Frankfurt), criticou certa concepção vulgar de alegoria confundida com a noção de símbolo. Atentou nessa crítica para suas confusões adjacentes que desconectam o nexo entre forma e conteúdo e entre o objeto físico e o metafísico. Esse último nexo é o mais interessante do ponto de vista da crítica benjaminiana por atentar para as origens teológicas dos conceitos de símbolo e alegoria. De todo modo, não estamos estudando o drama barroco alemão e sim o quadrinho histórico. Para nosso entendimento nos serve uma noção genérica da imagem alegórica como expressão de um conceito (BENJAMIN, 1985, p. 19), pois é através desse recurso que são figurados certos conceitos históricos.

Sua tradição já remontava à iconografia política anterior, que representava ideais políticos, como a república, a democracia, etc. na forma de musas, e essas remontavam ao papel da alegoria na mitologia clássica. Enviesadamente e de acordo com sua têmpera iconoclasta, a caricatura da imprensa ilustrada do século XIX encarregara-se de profanar tais ícones políticos. O expediente alegórico é bastante utilizado nos quadrinhos da coleção Redescobrindo o Brasil, e com relação a esse pormenor podemos situá-los na continuidade da tradição caricatural oitocentista.

A aparição de personagens alegóricos se dá, por exemplo, por ocasião da representação dos partidos liberal e conservador em Cai o Império. Tais instituições são representadas na figura de irmãos gêmeos de condição social notadamente elitista. A fraternidade univitelina representa caricaturalmente, isto é, acentua o fato de que na prática política as diferenças entre tais partidos eram mínimas uma vez que representavam os interesses de uma mesma elite. Nessa imagem alegórica instituições políticas assumem um aspecto visível em um primeiro momento. E no segundo momento um caráter dessas instituições frequentemente enfatizado pela historiografia - a saber, sua unidade de interesses 
classistas - é "carregado" pelo traço caricatural que os representa com a "cara de um" e o "focinho de outro".

Outra alegoria recorrente na coleção, menos original e mais convencional, é a que alude aos imperialismos nacionalistas britânico e norte-americano nas figuras do inglês vitoriano e do personagem alegórico internacionalmente conhecido como Tio Sam. É interessante notarmos de passagem o papel histórico da caricatura na ressignificação desse último personagem, que fora cunhado para fins de propaganda nacionalista norte-americana, mas cujo caráter simpático foi subvertido pela crítica caricatural em todo o mundo para ser transformado finalmente em vilão de ares prepotentes.

Outras alegorias podem possuir um caráter funcional no âmbito da própria linguagem quadrinística, como é o caso da representação figurativa do racismo cientificista do século XIX na figura 38. Para representar o conjunto de idéias em questão, Angeli lançou mão de clichês estereotípicos de representação da figura do cientista (como é o caso da expressão "eureca", dos tubos de ensaio e da "cobaia" enjaulada) juntamente com a representação mais fidedigna de um dos principais métodos do racismo cientificista, a antropometria (realizada por seu assistente). Aqui um conjunto de idéias é representado através da intromissão de objetos da cultura material que não estão historicamente relacionados a elas porque enfatizam sua pretensão científica. A representação visual de elementos da cultura material sem um compromisso tão fiel para com os rigores da pesquisa iconográfica é frequente na coleção. Esse tipo de uso (ou abuso) de elementos visuais historicamente descontextualizados levanta um impasse formal: por um lado, compromete o aspecto de historiografia visual da figuração (sugerido por Burke); por outro, possui uma função significativa no sentido de enfatizar um conceito através de convenções alegóricas.

Caso parecido se dá em outra passagem. Nela a explicação histórica de que o fim do escravismo colonial brasileiro está ligado predominantemente a interesses econômicos industriais é ilustrada por Angeli pela comparação de alegorias da cultura material [fig. 40]. Ali a figura do escravo é colocada entre a enxada e a máquina, elementos que representam dois sistemas de produção econômica, o escravismo e o industrialismo. A máquina, por sua vez, cospe sapatos em série na cabeça do escravo. No caso do sapato, temos um elemento cuja significação como símbolo de liberdade no pós-abolição se deu no próprio processo histórico 
em questão, uma vez que o costume senhorial vetava seu uso por parte dos escravos. Tal composição, em seu nonsense cartunístico que mescla elementos improváveis em um cenário etéreo obtendo dessa forma uma cena infactível e disparatada, parece estar mais próximo da representação alegórica que o exemplo anterior. Por meio da representação de elementos da cultura material que atuam como símbolos combinados conforme uma lógica histórica, alegoriza uma explicação causal da história assim materializando o imaterial, ou mais exatamente, concrecionando o abstrato. 


\section{2. 1. 2. Coleção de quadrinhos?}

Essa última ilustração alegórica é oportuna para problematizarmos a definição genérica dos livros da coleção analisada. Suas características de linguagem com recursos aos mais variados gêneros dos quadrinhos, da ilustração literária, do jogo, etc., fazem da tarefa de enquadrá-las em um gênero específico com base em sua estrutura formal bastante difícil. Vemos o problema complicando-se se tomarmos a definição de Paulo Ramos em sua análise da especificidade da linguagem dos quadrinhos segundo a qual caricatura e ilustração não são gêneros quadrinísticos por não constituírem narrativas (RAMOS, 2009, p. 20).

O problema aqui se refere ao fato de que ambos esses gêneros são utilizados no interior de uma narrativa predominantemente verbal em que a imagem atua na maioria das vezes como ilustração isolada do texto escrito, não atuando aí como elemento narrativo em relação sequencial com outras imagens. Ainda quando essa imagem sequencial aparece, geralmente por meio do recurso à tira cômica, ocorre que a mesma também atua no sentido de ilustrar uma idéia previamente verbalizada. Essa limitação formal que distancia tais obras do rótulo quadrinístico é, possivelmente, efeito colateral da própria proposta de produção das mesmas, em que há uma marcada divisão de tarefas na produção dos textos verbal e imagético.

Há ainda à dificuldade de classificação trazida por elementos extra-textuais aludida pelo mesmo autor (RAMOS, 2009, p. 19). No caso, refere principalmente às intenções autorais e expectativas de leitura. A coleção possui uma marcada intenção de ser, em seu conjunto, um livro de quadrinhos e o leitor assim o recebe. Essa marca pode ser deduzida do fato de estarem envolvidos na empreitada dois destacados artistas da cena quadrinística nacional. Embora em nenhum momento a coleção se auto-rotule enquanto história em quadrinhos, sua apresentação como um todo assim sugere.

Outro problema interessante surge quando da identificação de um público-alvo. Os temas emergem do currículo escolar, a linguagem é simplificada e lúdica. Não obstante, há uma série de elementos de seu conteúdo que hoje dificultariam sua aceitação irrestrita no 
ambiente escolar. Trata-se do teor de seu humor, que hoje seria considerado inadequado para o público escolar se levarmos em conta as polêmicas recentes que envolveram algumas obras de quadrinhos nesse ambiente. Na obra Cai a república (...) o tratamento da questão racial brasileira é tratado com ironia ambivalente no uso de termos considerados usualmente racistas. Em Olha lá o Brasil (...) existe um humor erotista, como na passagem que parodia a escrita da carta de Pero Vaz de Caminha, outro forte tabu cultural especialmente zelado no ambiente escolar. Fruto de um período em que o humor brasileiro não possuía rédeas e corria solto por todos os lados se comparado ao cerceamento que o mesmo vem adquirindo recentemente. Na maior parte dos casos, trata-se de contestações legitimas de grupos mais comumente atingidos pelo humor, como é o caso da população afro-descendente e do gênero feminino. Apesar de partirem de um ponto de vista mais identificado com o "homem branco", tais gracejos não podem ser peremptoriamente sentenciados como sendo machistas ou racistas. Não cabe aqui, entretanto, aprofundar essa problemática, que apesar de estar vinculada às tradições do humor na linguagem quadrinística, diz mais respeito ao problema das funções sociais da cultura histórica que de sua formatação.

O problema que melhor nos cabe é: afinal, a coleção Redescobrindo o Brasil é uma coleção de quadrinhos ou de literatura didática ricamente ilustrada? Cremos que a solução é um meio termo entre as duas. O que nos interessa mais detidamente que a identificação genérica é o reconhecimento do caráter experimental dessas obras que emprestam recursos de diversas linguagens, muitas delas propriamente quadrinísticas, com o objetivo de buscar uma forma de divulgação do conhecimento histórico, por assim dizer, mais informal e inovadora. 
CARA DEUM, FOCINHO DO OUTRO, COSTUMAM DIZER, ASSIMERAM OS LIBERAIS EOS CONSERVADORES. TANTO QUE CHEGARAM A SENTAR NO MESMO ASSENTO. DE 1853 ATÉ QUASE 1870 GOUERNARAM JUNTOS. FORAM ANOS FELIZES. FAZIAM UM PAR PERFEITO QUE ATE GANHOU O SUGESTIVO NOME DE CONCILIACAO. AS DIFERENGAS FORAM ANIQUILADAS EA LUTA PELD PODER HAVIA SIDO SUPERADA. FINAL FEUIZ?

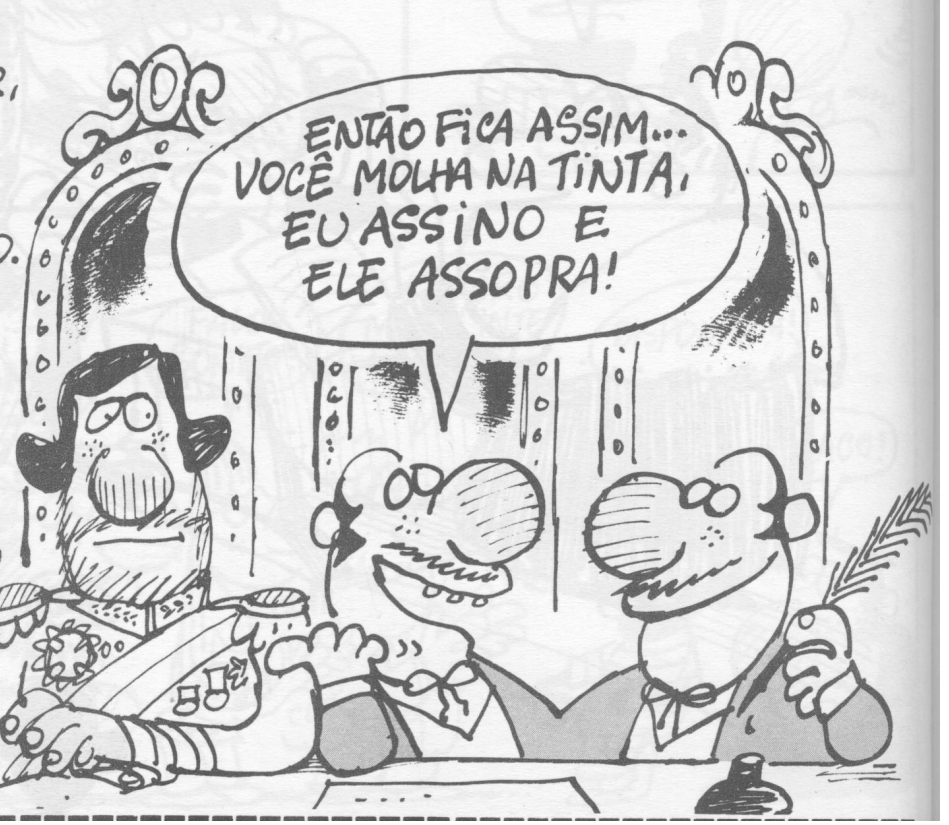

Figura 37 (ANGELI; SCHWARCZ, 1983, p. 18) 
EAGORA? OS RERUBLIEANOS TERIAM QUE FALAR EM IGUALDADE PERANTE UMA MASSA DE EX-ESCRAVOS COM DIREITO 'A CIDADANIA. ENTAO, AS TEORIAS SURGIRAM RAPIDINHO. COMEPAM A APARECER DISCURSOS CiENTÍFicos QUE, FUNDAMENTADOS GM"DADOS $E$ FATOS INQUESTIONAUUES", DEFENDIAM E PRETENDIAM PROUAR A DESIGUALDADE NATURAL DAS RACAS*
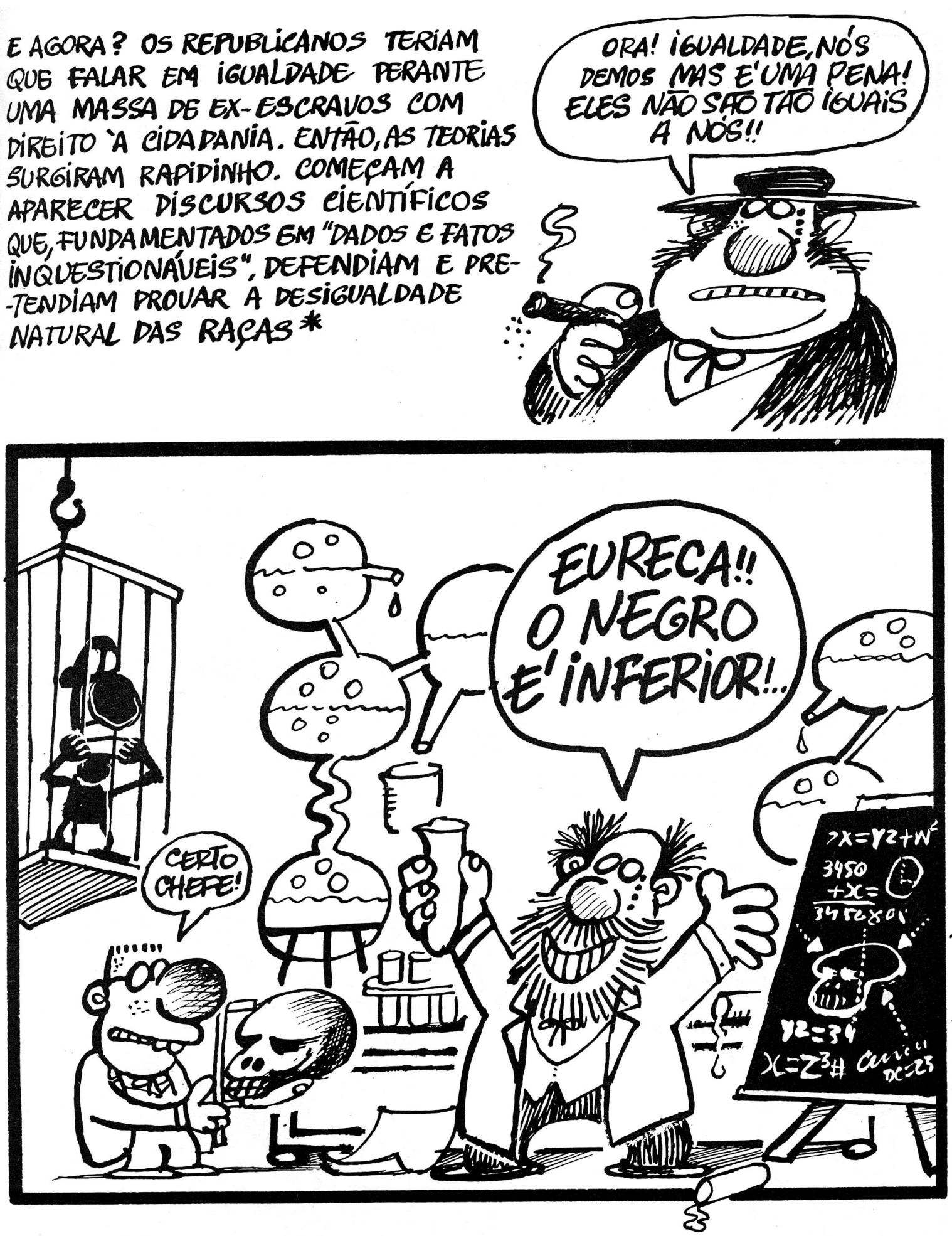

* Nina rodrigues, por exemplo, famoso médico baiano, afirmaua, na época, ser IMPOSSIVEL UM EX-ESCRAMO TER UM cOMPORTAMENTO CIVILIIZADO. 
D

\section{A VROUENNGPARPANOA}

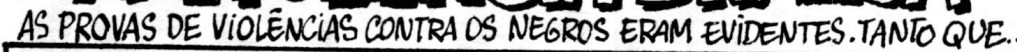

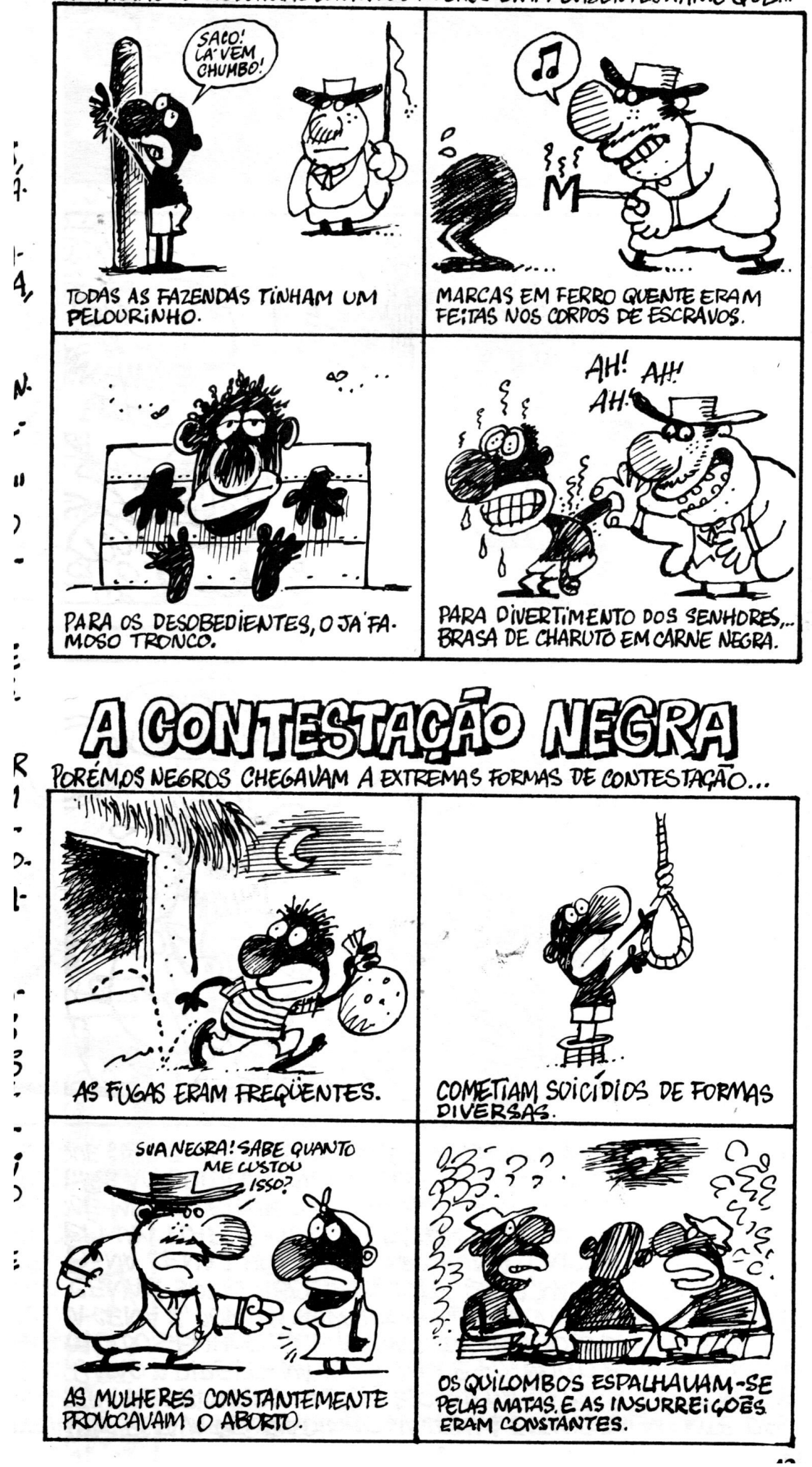

Figura 39 (ANGELI; SCHWARCZ, 1983, p. 43) 
ENQUANTO ISSO, OUTRA CONTRADIFÃO TAMBÉM CORRDÍA AS BASES DO IMPÉRIO...

CONSOME, NEGAOO!CONSOME! O CAPITALISMO INDUSTRIAL E A ESCRAVIDĀO INCOMPATIBILIZAVAM-SE. O ESCRAUO POR EXCELENCIA NĀO CONSUMIA, IMPEDINDO A FORMACÁO DE GRANDES MERCADOS CONSUMIDORES. POR ISSO,
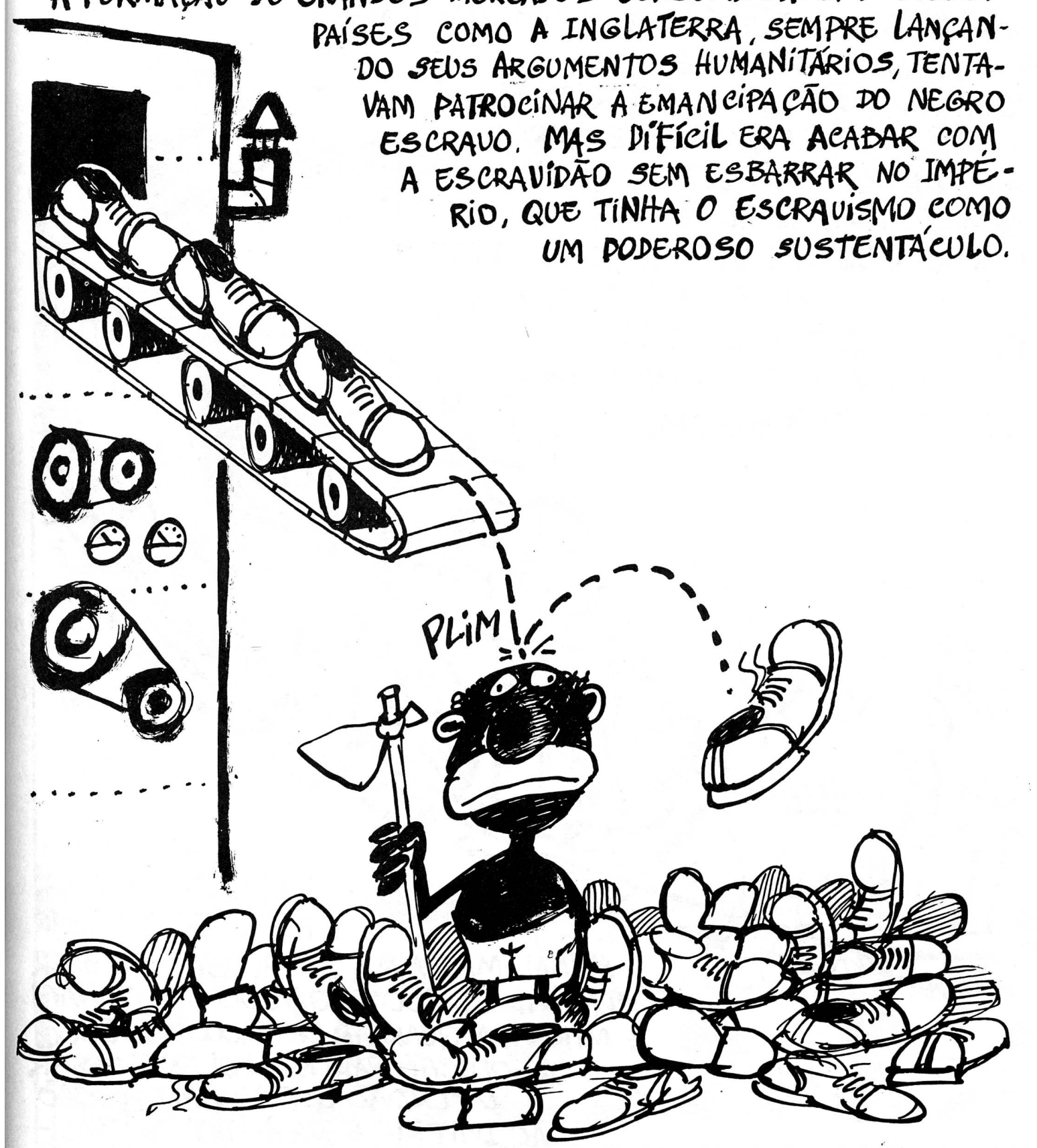

Figura 40 (ANGELI; SCHWARCZ, 1983, p. 55) 
PRONTO, O PODER TROCOU DE MĀOS E O POVO ASSISTIU A ESSE ESPETÁ́cULO MEIO INDIFERENTE E ACEITANDO QUASE TUDO COMO UM EATO CONSUMADO.
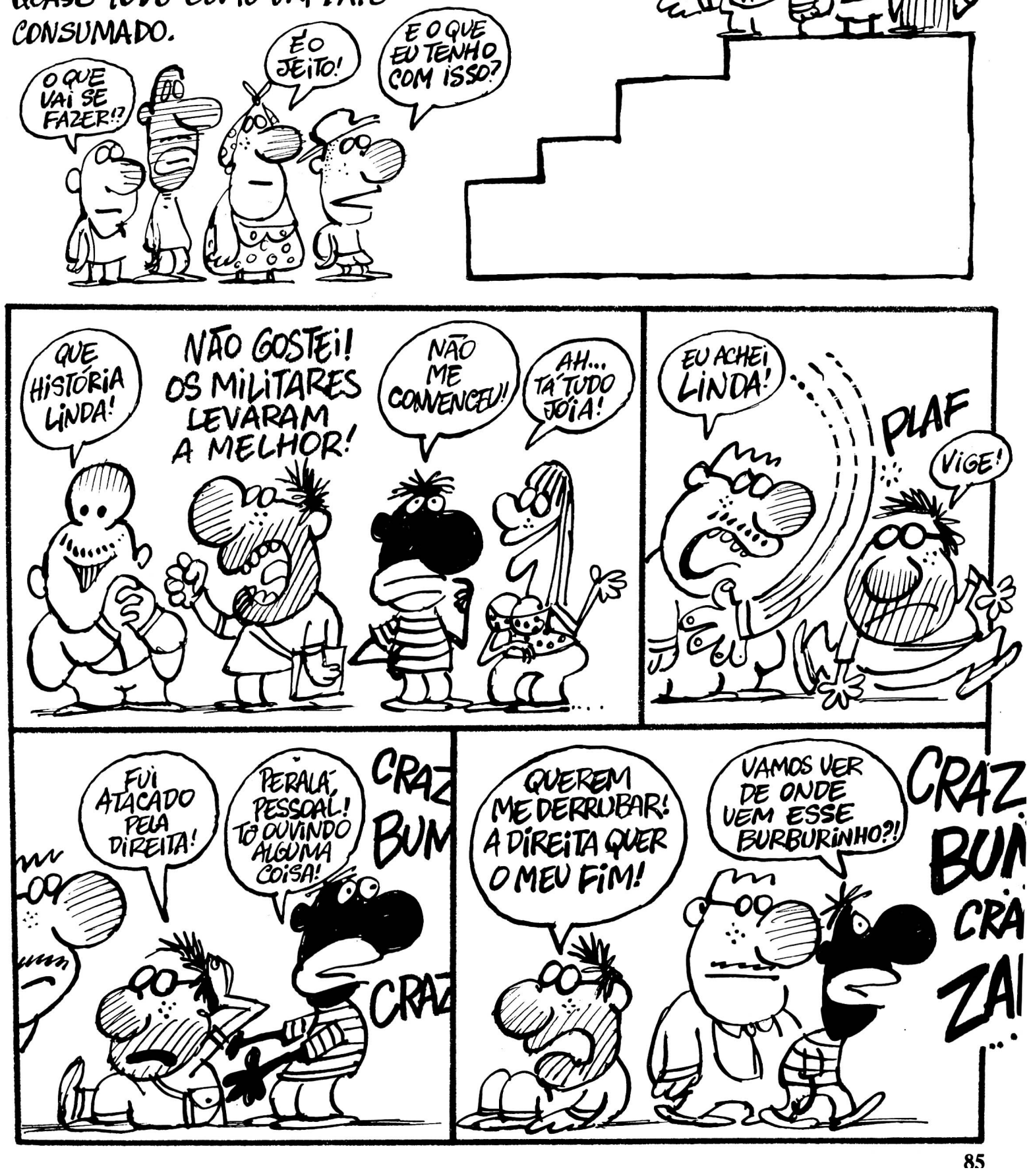

Figura 41 (ANGELI; SCHWARCZ, 1983, p. 85) 


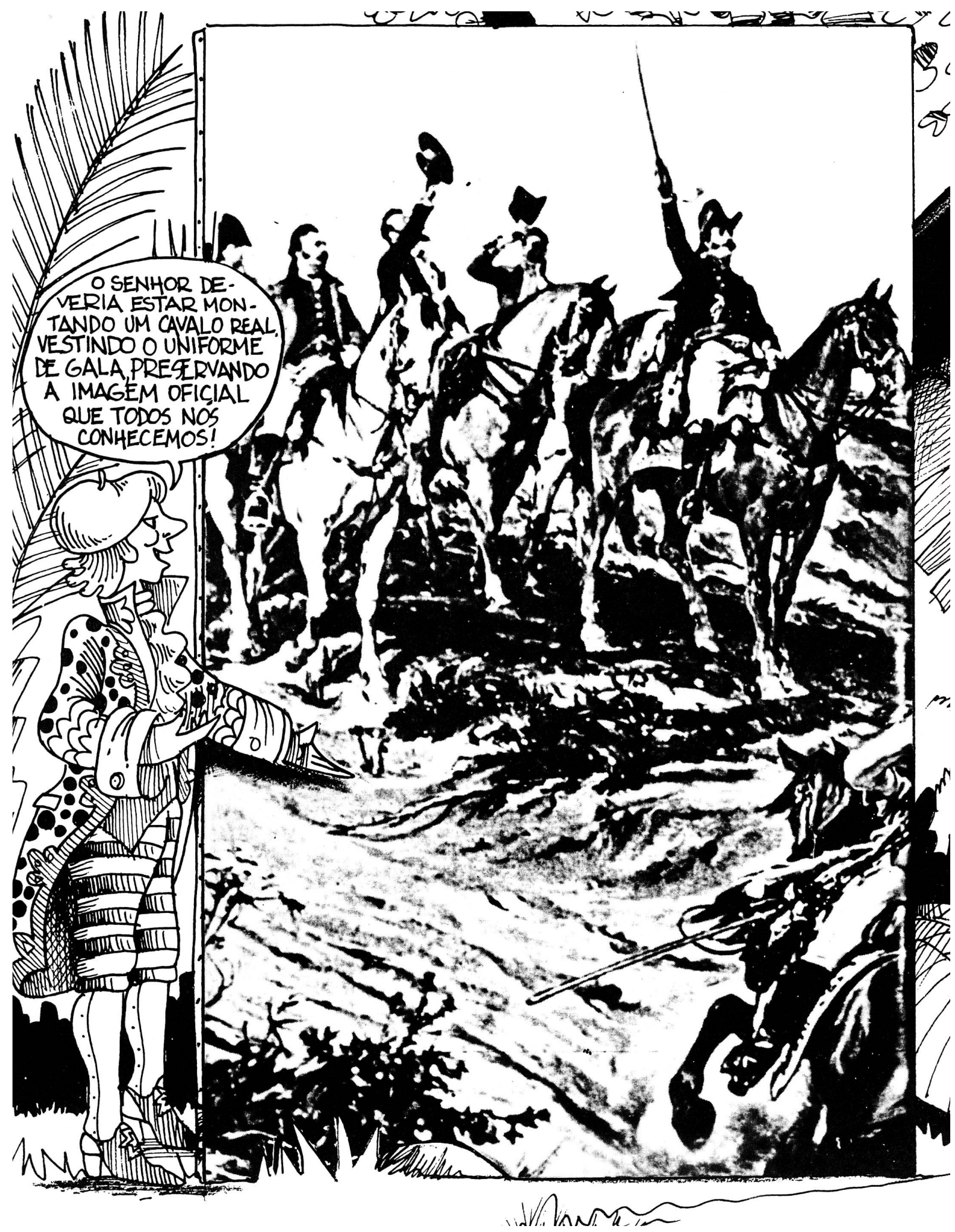

Figura 42 (PAIVA; SCWARCZ, [desc.], p. 8) 

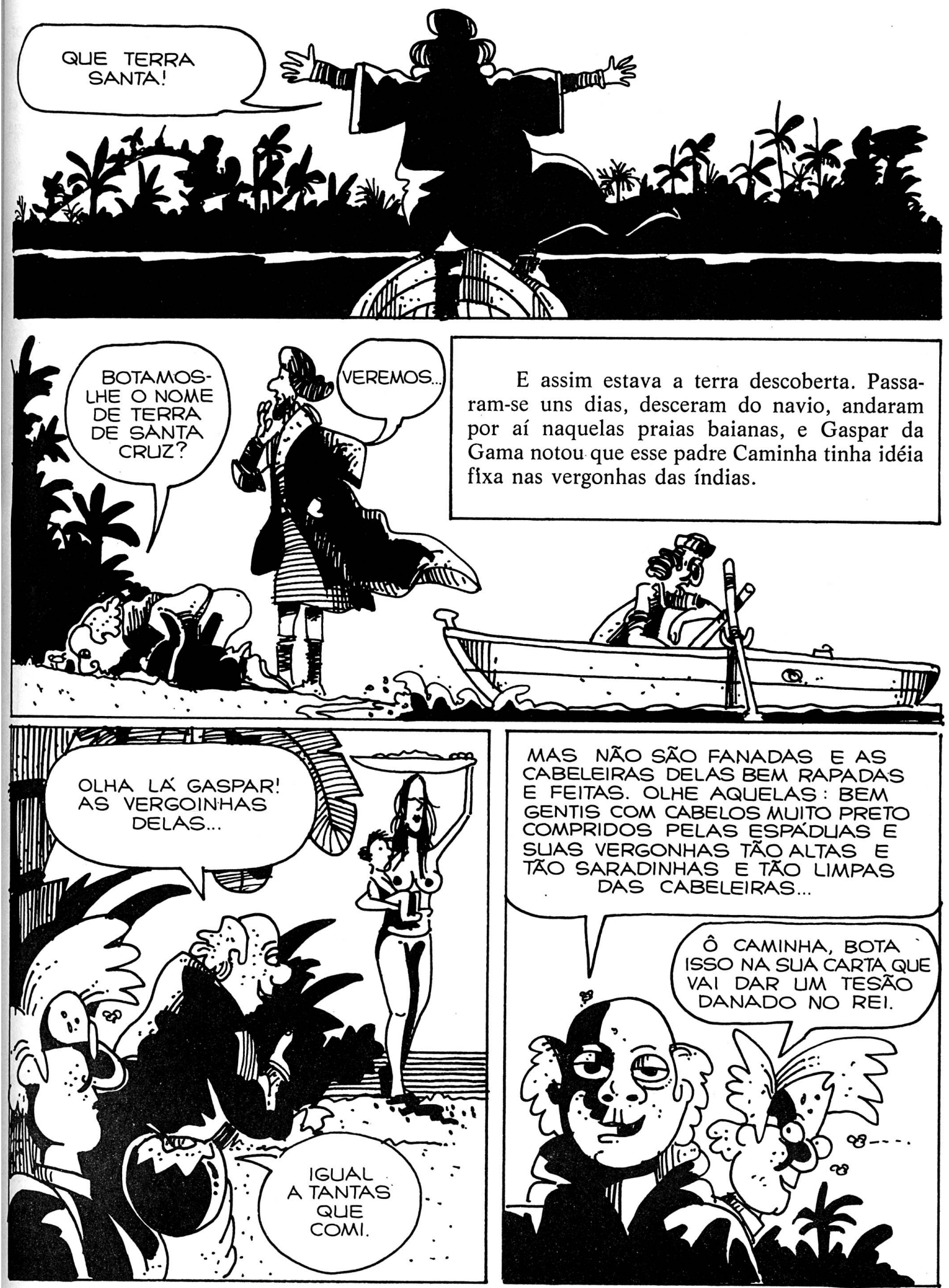

MAS NÃO SÃO FANADAS E AS CABELEIRAS DELAS BEM RAPADAS E FEITAS. OLHE AQUELAS: BEM GENTIS COM CABELOS MUITO PRETO COMPRIDOS PELAS ESPÁDUAS E SUIAS VERGONHAS TÃO ALTAS E TAOO SARADINHAS E TÃO LIMPAS DAS CABELEIRAS...

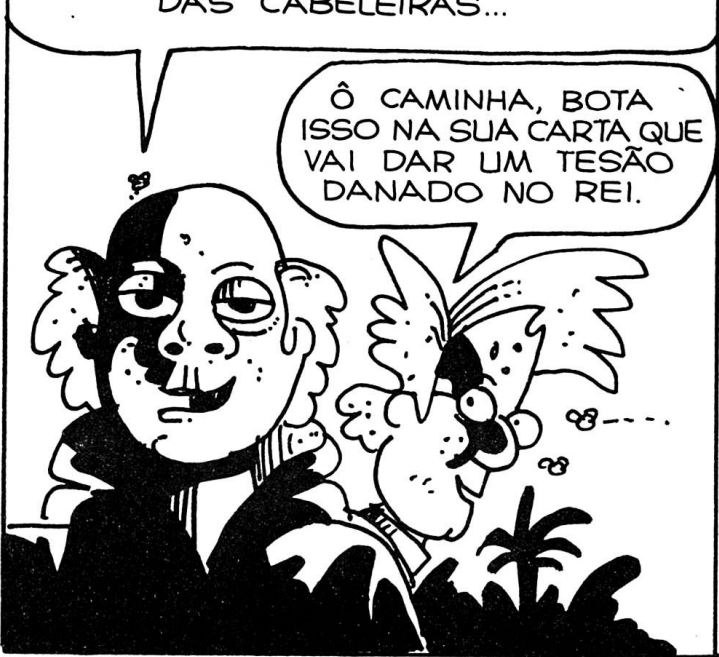

Figura 43 (CHIAVENATO; PAIVA, [desc.]. p 61) 


\subsubsection{João Carioca (...): o quadrinho histórico de Schwarcz e Spacca}

A obra de Spacca é marcada pela narrativa histórica centrada nos personagens históricos consagrados, os "grandes homens" (e mulheres), mas, contrariamente à historiografia tradicional que também faz dos mesmos seu tema predileto, o cartunista lhes representa pelo viés da caricatura. Além da obra D. João Carioca (...), que narra a transferência da corte portuguesa para o Brasil no início do século XIX e nos servirá de fonte analítica, Spacca também dedicou álbuns ao aviador Santos-Dumont, em Santô e os pais da aviação: a jornada de Santos-Dumont e de outros homens que queriam voar; e ao artista francês Jean-Baptiste Debret em Debret em viagem histórica e quadrinhesca ao Brasil.

O quadrinho D. João Carioca situa-se em um contexto comemorativo do centenário da vinda da corte para o Brasil, e inclusive estampa um selo com um perfil do monarca e os dizeres “D. João VI no Rio: 1808-2008”. Recebeu quase em seguida a seu lançamento uma versão em desenho-animado exibida no Canal Futura, emissora televisiva ligada a corporação midiática Rede Globo cuja programação é orientada por certa preocupação educacional. A versão animada parece destinar-se a atingir um público mais amplo através do veículo televisivo, já que em suas linhas gerais não se diferencia muito do quadrinho.

No que se refere ao estilo gráfico de Spacca, a comparação mais justa parece aquela que liga este cartunista ao desenhista Uderzo, responsável pelo desenho da série francesa Asterix. Além das aproximações no estilo de representação da figura humana, outro aspecto marcante de aproximação é a representação do movimento em que essas mesmas figuras são imbuídas de um dinamismo próprio apesar do congelamento quadrinístico. É curiosa a contradição entre a versão do quadrinho e a versão animada nesse quesito, pois, nesta última, devido a limitações na técnica da animação, os personagens não possuem a mesma vivacidade que possuem nos quadros estáticos do primeiro. 


\subsubsection{Da representação caricatural de personagens históricos}

A propósito do personagem do rei Dom João VI polemizou-se em uma publicação especializada de história sobre a questão da representação caricatural do personagem ${ }^{2}$. $\mathrm{O}$ alvo foi principalmente sua representação como um glutão ignóbil e desprovido de relevância política nas produções cinematográfica Carlota Joaquina e televisiva Quinto dos Infernos, série da Rede Globo. O artigo em questão advoga que tais representações deturpam o real significado histórico do personagem. O D. João de Spacca é, porém, de uma caricatura mais refinada que as anteriores. Nela são carregados os traços de indecisão política sem o apelo à imagem de total inépcia ou de hábitos pessoais grotescos como é o caso do rei "devorador de coxinhas" interpretado pelo ator Marco Nanini no filme mencionado.

Tomando o termo "caricatura" em seu sentido amplo mais próximo da etimologia original (FONSECA, 1999), que já aludimos no sub-capítulo referente à obra de Toral, podemos considerá-la como uma forma de representação gráfica que pode ser empregada como recurso formal para a construção de uma história em quadrinhos histórica. A noção de caricatura como uma formatação gráfica é diferente da noção mais restrita de caricatura entendida como gênero (RAMOS, 2009, p. 20), que se refere ao retrato de um quadro apenas (portanto não sequencial). Originalmente a caricatura surge como gênero do desenho (mais especificamente como esboços no estudo de novas possibilidades formais de desenho da anatomia humana), mas o uso do termo também foi ampliado em seus desenvolvimentos a partir de sua inserção na crítica de outras formas de arte, como a literatura ou o teatro, por exemplo. Tomou-se como fator determinante do termo a identificação de seu método representacional "deformador", que carrega intencionalmente aspectos parciais da realidade representada. O problema representacional no caso é: tal deformação quantitativa dos pesos e medidas de um dado objeto implicaria em uma metamorfose do mesmo, ou seja, transformaria qualitativamente sua substância?

Gostaríamos de aproveitar a oportunidade levantada pela polêmica para discutir

Sem coxinha de galinha. Luiz Carlos Villalta e André Pedroso Becho, 07/01/2008. Disponível em http://www.revistadehistoria.com.br/secao/educacao/sem-coxinha-de-galinha Acesso em: jul./2012 
brevemente a questão da representação caricatural de personagens factuais. O problema diz respeito às particularidades dessa forma de representação, responsável em grande medida por uma relação de imitação deformadora da realidade e de alteridade crítica e irônica para com o objeto representado. A deformação da caricatura não é necessariamente historicamente deturpadora, ou seja, não necessariamente incorre na deformação do sentido histórico do fato representado. A caricatura permite inclusive enfatizar os traços definidores de tal personagem ou qual fato histórico, tornando assim evidentes suas características mais importantes mas não necessariamente óbvias por um ponto de vista menos aguçado, como é o caso da proporcionalidade mimética do realismo naturalista. Nesse caso, cremos que a caricatura é bastante adequada à narrativa histórica sintética, na qual as ênfases possuem destacada função comunicativa.

O processo de composição dos personagens, bem como de outros elementos históricos como a composição dos cenários e da cultura material, é explicitado pelo autor ao final do livro em uma seção anexa ao final do álbum dedicada ao processo de produção da história em quadrinho - uma espécie de making of. [fig. 49 - 52]. Nessa seção fica claro, por exemplo, que para a composição dos personagens também contribuem, além da referência à iconografia original dedicada à monumentalização contemporânea dos mesmos, referências secundárias retiradas do cinema e sobrepostas no desenho [fig. 42]. Certa crítica à construção monumental da iconografia de época é empreendida de passagem quando da menção às diferentes versões de Dom Pedro I [fig. 15]. Nessa passagem Spacca explicita sua opção de referência por um esboço de Debret ao invés do retrato mais famoso do personagem feito por Simplício Rodrigues de Sá. Em outro retrato de referência, o de lorde Strangford, Spacca ironiza com a legenda: "Strangford 'real". Como se tratam de retratos realizados anteriormente ao advento da técnica fotográfica, a relação de verossimilhança da representação figurativa é de outra ordem. Daí advém também a maior liberdade do artista em se valer de outras referências para preencher as lacunas da documentação iconográfica, como é o caso da referência a atores do cinema que personificam um dado traço de caráter.

Os anexos à história em quadrinhos ainda incluem uma cronologia sumária do período em que se passa a narrativa e uma bibliografia de obras de referência, sendo a maior parte delas historiográficas. Na seção acima referida, alguns poucos documentos são postos ao lado dos esboços do quadrinho acrescidos de breves comentários. Assim como os anexos do 
álbum Adeus Chamigo (...) de André Toral, não constituem o que se pode chamar de uma ampla explicitação e aprofundamento das relações entre a pesquisa iconográfica e a formatação quadrinística das mesmas. Estão mais próximas de um complemento dedicado à curiosidade do leitor. Spacca, contudo, apresenta suas fontes situadas no contexto da produção quadrinística propriamente dita, e, dessa forma, lembra-nos do caráter de construção do processo de representação histórica, ao passo que Toral, por apresentar em anexo a seu álbum suas fontes documentais em estado bruto e um texto sóbrio de síntese historiográfica, confere maior peso ao caráter de verificabilidade e conseqüente expectativa de verossimilhança em uma representação dessa natureza.

Há, claro, entre os dois casos, o de Adeus Xamigo (...) e o de D. João Carioca (...), uma diferença no que se refere a fundamentação em pesquisa histórica, que no primeiro caso não esteve ligado exclusivamente a fins de sua formatação quadrinística. Nos dois casos a pesquisa em fontes secundárias (que são referenciadas em uma bibliografia) é somada a pesquisa iconográfica. Mais uma vez, nesse âmbito também diferem-se por ser a primeira de autoria individual e a segunda de autoria colaborativa. Diferentemente do que ocorre nas parcerias da coleção Redescobrindo o Brasil, entretanto, em que há uma divisão de tarefas mais demarcada pelos loci acadêmico e quadrinístico, na parceria entre Schwarcz e Spacca há uma maior responsabilidade do quadrinista na formatação global da obra. À primeira é creditada a pesquisa e supervisão, ao segundo também é atribuído o crédito da pesquisa juntamente ao do roteiro e dos desenhos. Presume-se que para escrever o roteiro o quadrinista aprofundou-se em pesquisa histórica geral, não se atendo aos aspectos visuais da história provenientes de uma pesquisa restrita à iconografia e à cultura material. Também notamos que, assim como na obra de Toral, a cultura material é historicamente informada também em seus usos e funções.

Já em comparação às obras da coleção Redescobrindo o Brasil, as diferenças na dinâmica de seu sistema colaborativo parece ter sido crucial na coesão dessa última história em quadrinhos em comparação com aquelas. Por certo que constituem experiências diferentes, sendo que em $D$. João (...) há uma maior aproximação do modelo de quadrinho histórico que esboçamos por se tratar de um romance gráfico. 


\subsubsection{A referência documental em $D$. João Carioca (...)}

Assim como na análise empreendida sobre o quadrinho de Toral em que observamos de que modo é formatada a crítica documental pelo autor, trataremos agora do mesmo aspecto na obra de Schwarcz e Spacca. O tipo de documento mais referido nesse último quadrinho é a pintura histórica. Essa referência se dá de formas diferentes das presentes naquela primeira obra. Uma das primeiras referências à pintura histórica é paródica [Fig. 44]. Nessa paródia se nota mais especificamente uma caricatura do estilo épico de pintura histórica. Spacca compõe um quadro segundo convenções formais da pintura da época e lança uma releitura irônica para com sua monumentalidade posada.

À exceção de uma referência direta, em que uma obra de época é reproduzida como um quadrinho em uma seqüência episódica [fig. 45], todas as demais serão apresentadas na forma de releituras. Na figura em questão, uma caricatura da cerimônia do "beija-mão" feita por um viajante inglês, o documento original ganha vida nos quadros seguintes, em que seus personagens adquirem voz. O episódio tem lugar nessa página que é a única em que a colorização sofre uma mudança com relação aquela padronizada no resto da história para se aproximar das cores aquareladas da caricatura original. Por certo que este tipo de tratamento toma a caricatura como ponto de partida plausível para retratar o fato. De toda sorte, a aparente referência não criticada a um documento, ou seja, sua apresentação como retrato fiel do fato, não é necessariamente pressuposta nesse uso do referente documental. Isso porque se trata justamente de uma caricatura, e, através de sua continuação, também caricatural, na narrativa que se segue de certa forma desresponsabiliza o método representacional do compromisso formal realista.

As pinturas tomadas como documentos são referenciadas com uma nota ao lado do quadro, uma espécie de nota de rodapé que identifica a matriz da releitura ali empreendida. As obras de época são geralmente situadas como ilustração dos fatos que pretenderam representar ou como quadros na sequência narrativa, tornando assim a crítica documental mais rarefeita. Esse é elemento interessante de comparação entre essa história em quadrinhos e a de André Toral, que pretendia fazer por meio dos quadrinhos uma reconstrução histórica fluída, "sem 
notas de rodapé” (TORAL, 1997, p. XV). Toral faz isso geralmente apresentando os documentos não como dados, mas como construtos.

Um caso dessa forma de apresentação em D. João (...) se dá na página 56 [fig. 46], em que, assim como no episódio envolvendo o pintor Victor Meirelles em Adeus Xamigo (...), é apresentado o contexto de produção do documento referido. Trata-se de uma página dedicada à apresentação da missão artística francesa no Brasil, e, no último quadro, em que é apresentada a releitura de uma gravura de Debret (artista da missão), a legenda empreende uma observação crítica sobre o "sotaque francês" de seu estilo. A representação do contexto de produção documental ainda se fará presente quando da apresentação do surgimento da imprensa no país [fig. 47]. A crítica do documento se dá nesse caso principalmente através da observância das relações de cumplicidade secreta entre o poder monárquico e o jornal. 


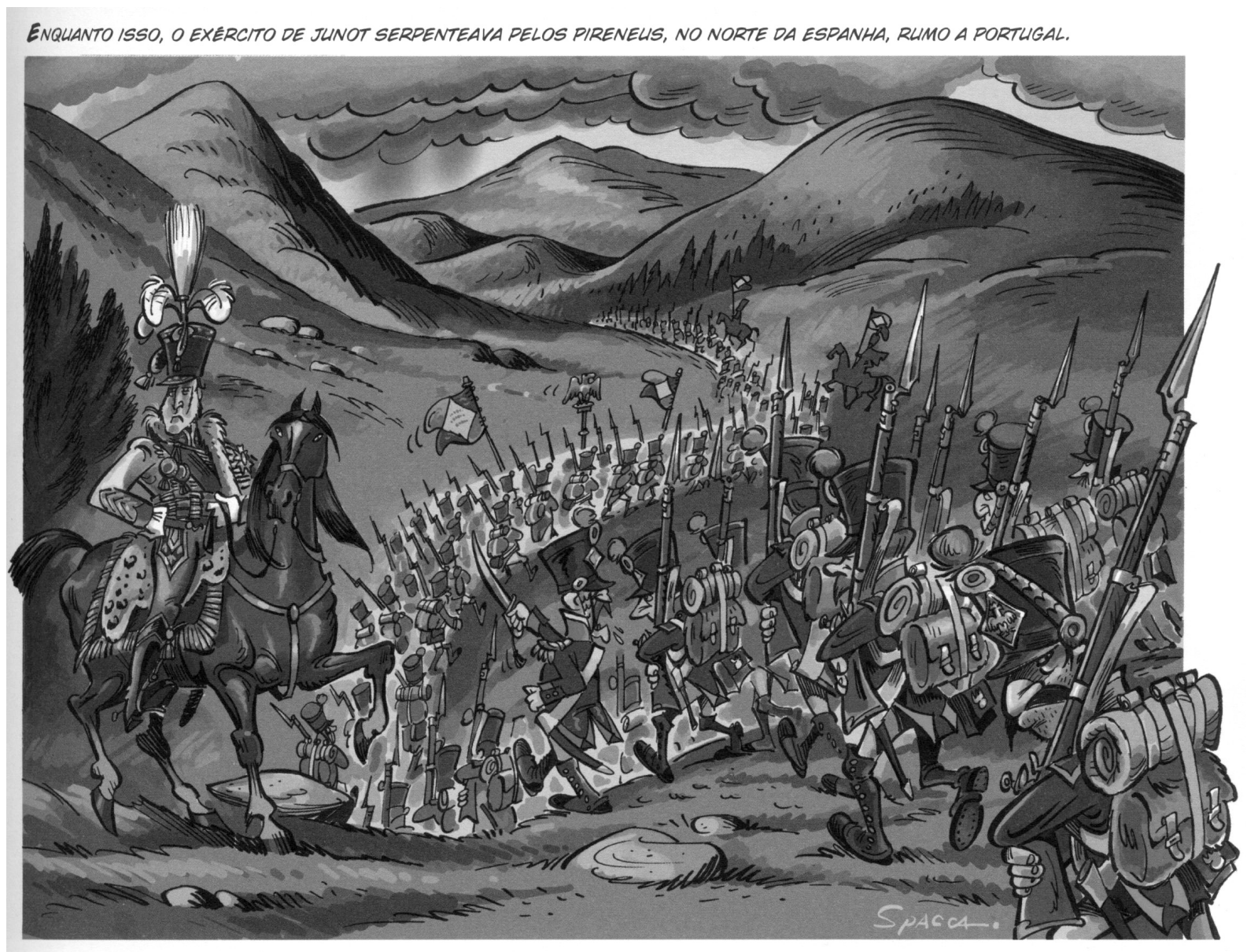

Figura 44 (SCHWARCZ; SPACCA, 2007, p. 15) 

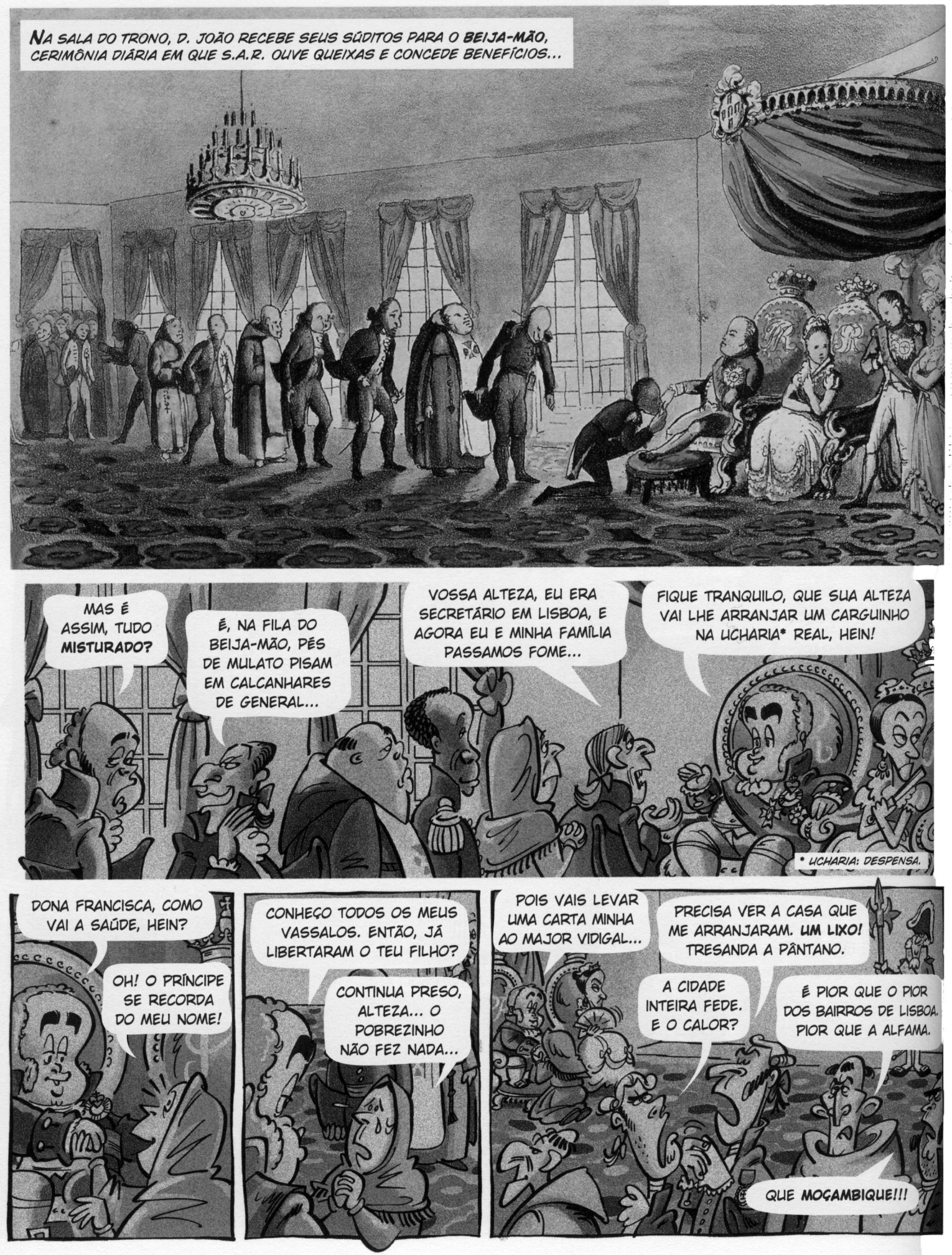

Figura 45 (SCHWARCZ; SPACCA, 2007, p. 32) 

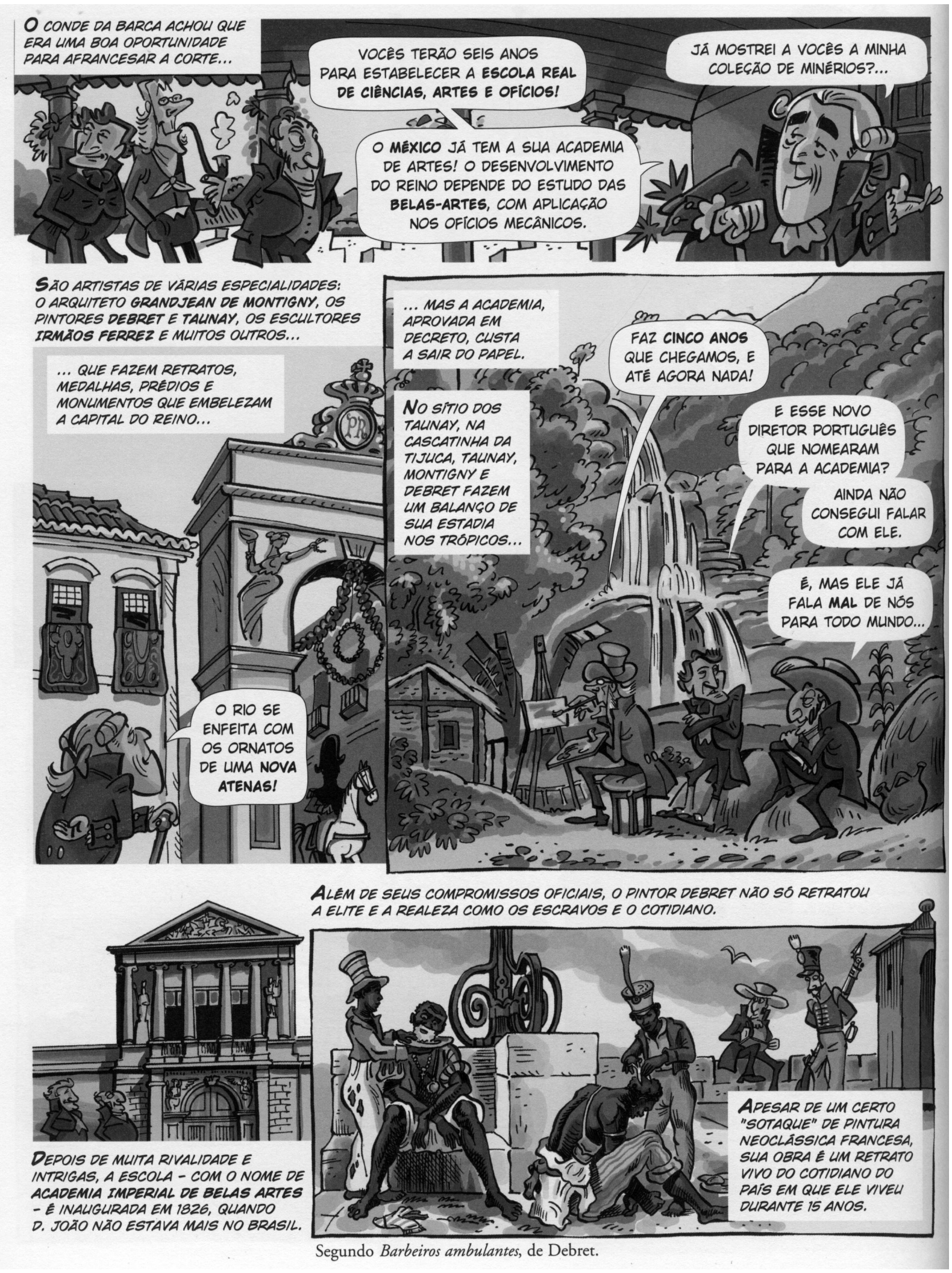

Figura 46 (SCHWARCZ; SPACCA, 2007, p. 56) 

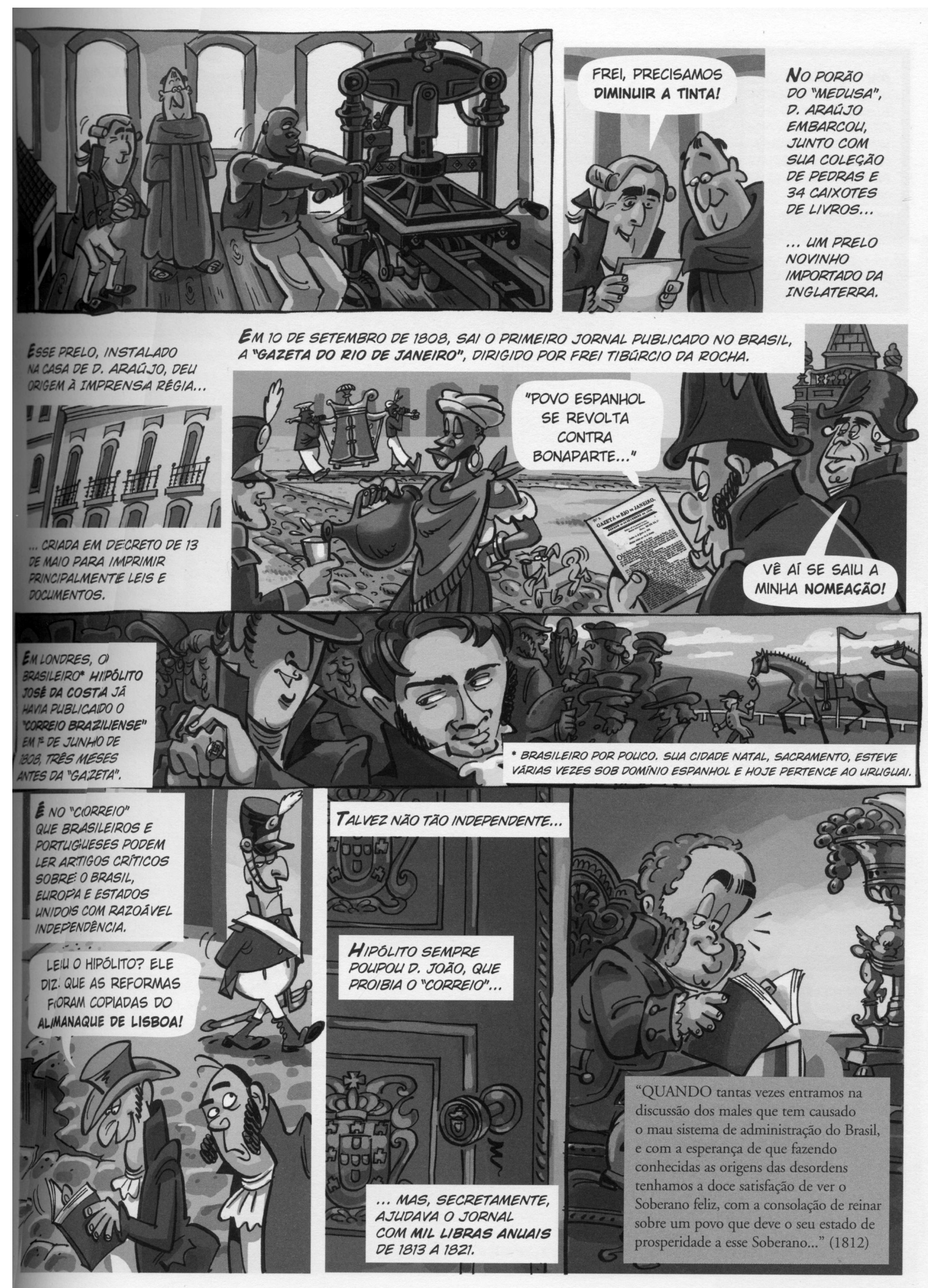

Figura 47 (SCHWARCZ; SPACCA, 2007, p. 35) 


\subsubsection{O problema do anacronismo}

Há diversas formas de incidência de anacronismos nos quadrinhos que se propõe à comunicar o conhecimento histórico. Geralmente são acidentes do descompromisso para com o rigor de erudição que seu conhecimento factual exige. Há alguns anacronismos, entretanto, que são intencionais. Sua função nesse caso é lúdica. Trata-se de uma brincadeira com o descompasso nas informações históricas, e é justamente dessa incoerência que surge o chiste anacrônico. Na imagem em questão [Fig. 48], D. João é saudado pelos baianos com uma expressão idiomática que hoje é muito utilizada na caricatura de sua regionalidade. Mesmo se a expressão já estivesse em uso no início do século XIX, esse uso estereotípico pode ser considerado um anacronismo, principalmente porque se trata de um tratamento informal que dificilmente se dirigiria a um monarca à época. Esse uso do anacronismo é muito freqüente em representações cômicas da história, sendo um dos recursos humorísticos mais recorrentes em séries como dos quadrinhos de Asterix ou das comédias históricas do grupo teatral britânico Monty Python. O fator importante a ser observado nesse caso de anacronismo de função anedótica é que para que o mesmo possua efeito cômico necessita ser reconhecido enquanto tal e, para tanto, requer certo conhecimento histórico por parte do leitor. Poderíamos quem sabe atribuir essa operação a uma consciência cômica da história, na qual, além de "fazer graça” da mesma, "acharíamos graça” também em suas ironias intrínsecas.

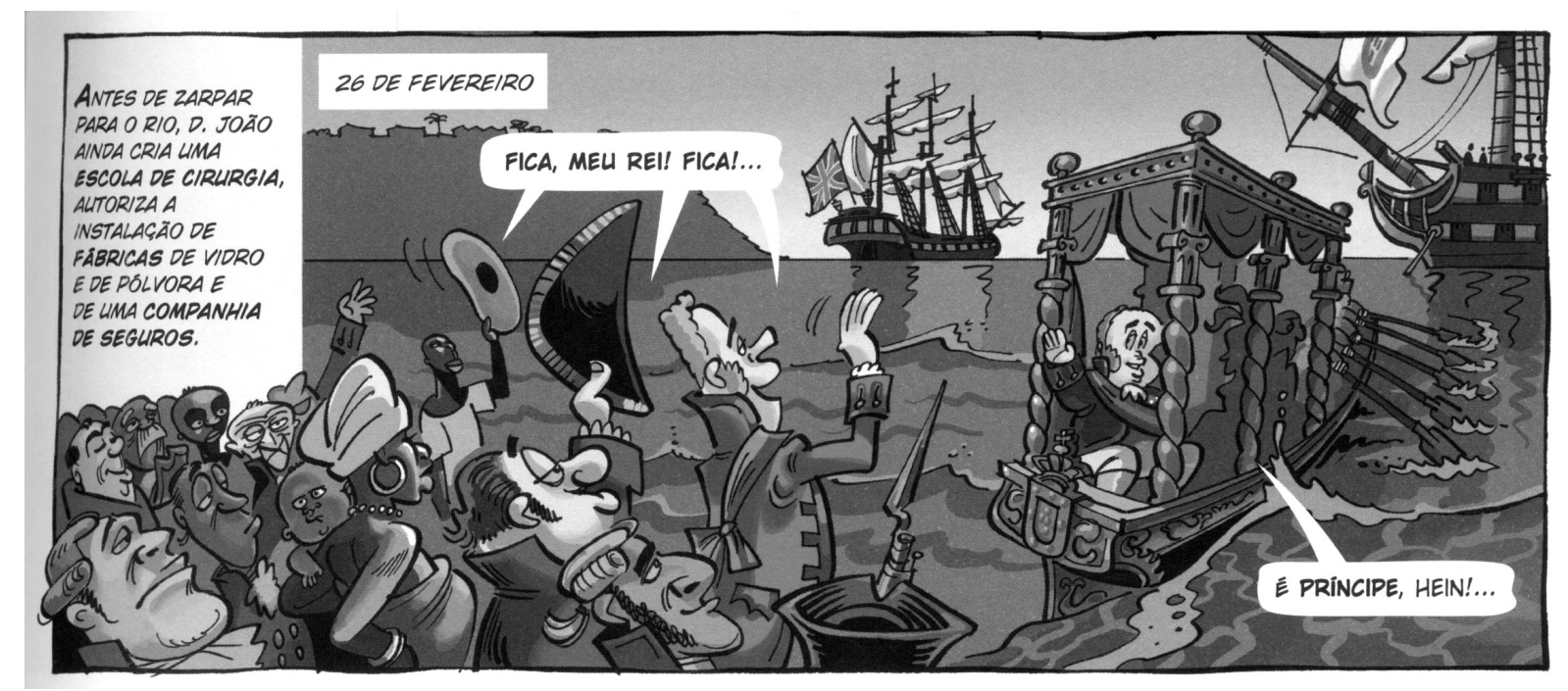

Figura 48 (SCHWARCZ; SPACCA, 2007, p. 27) 


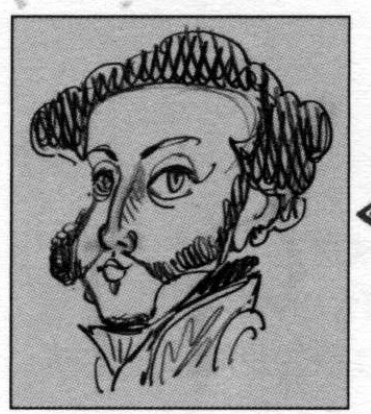

ESTE É O RETRATO MAIS FAMOSO DE

D. PEDRO, POR

simplício rodrigues DE SA'. MAS SEMPRE ACHEI ESTRANHO. (PARECE uM QuerubiM)

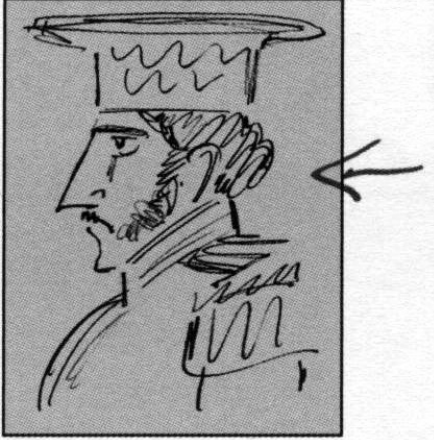

AcREdTo qLE ESTE ESBOGO FETO POR DEBRET, AO VIVO, SEJA MAIS FIE.

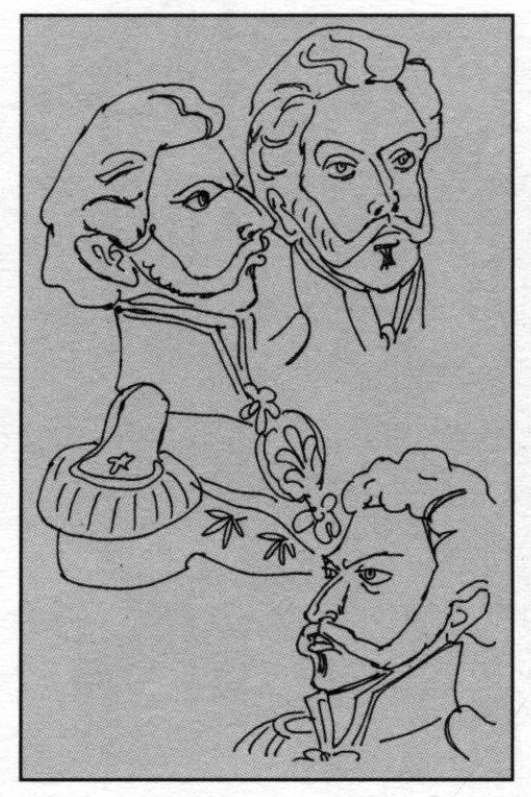

ESCULTURA DE MARC FERREZ গ nO MUSEU NACIONAL.

Figura 49 (SCHWARCZ; SPACCA, 2007, p. 90)

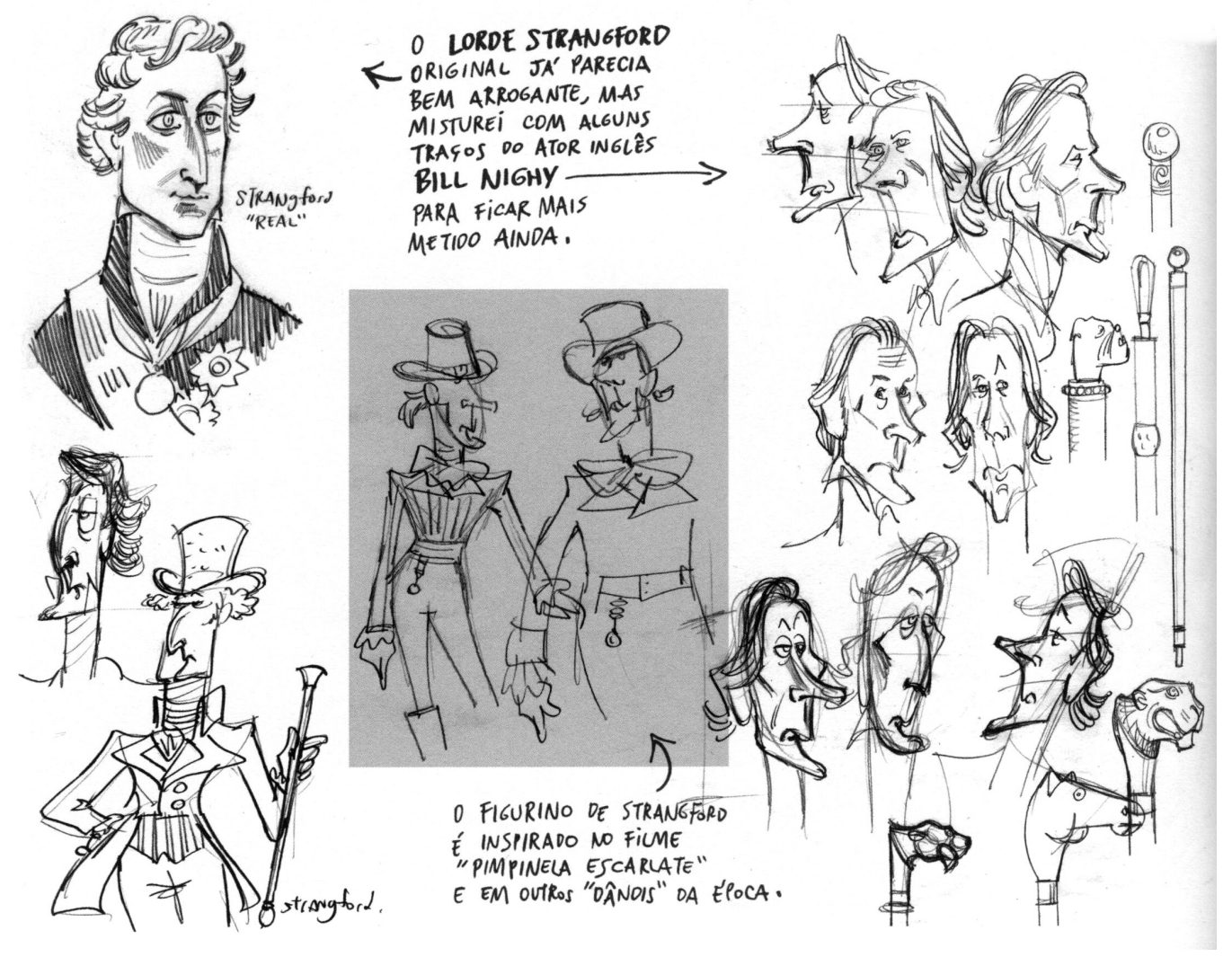

Figura 50 (SCHWARCZ; SPACCA, 2007, p. 82) 


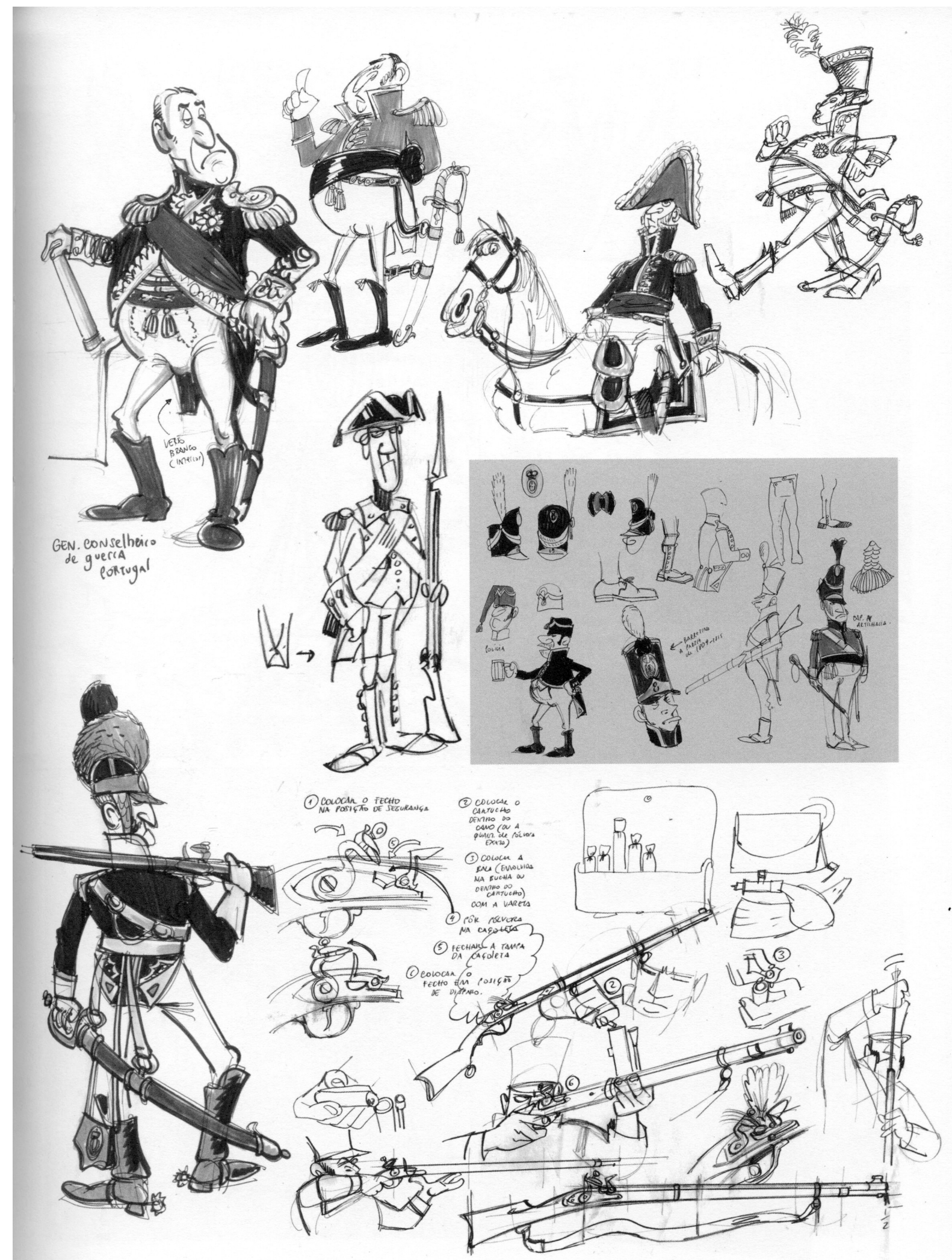

Figura 51 (SCHWARCZ; SPACCA, 2007, p. 87) 


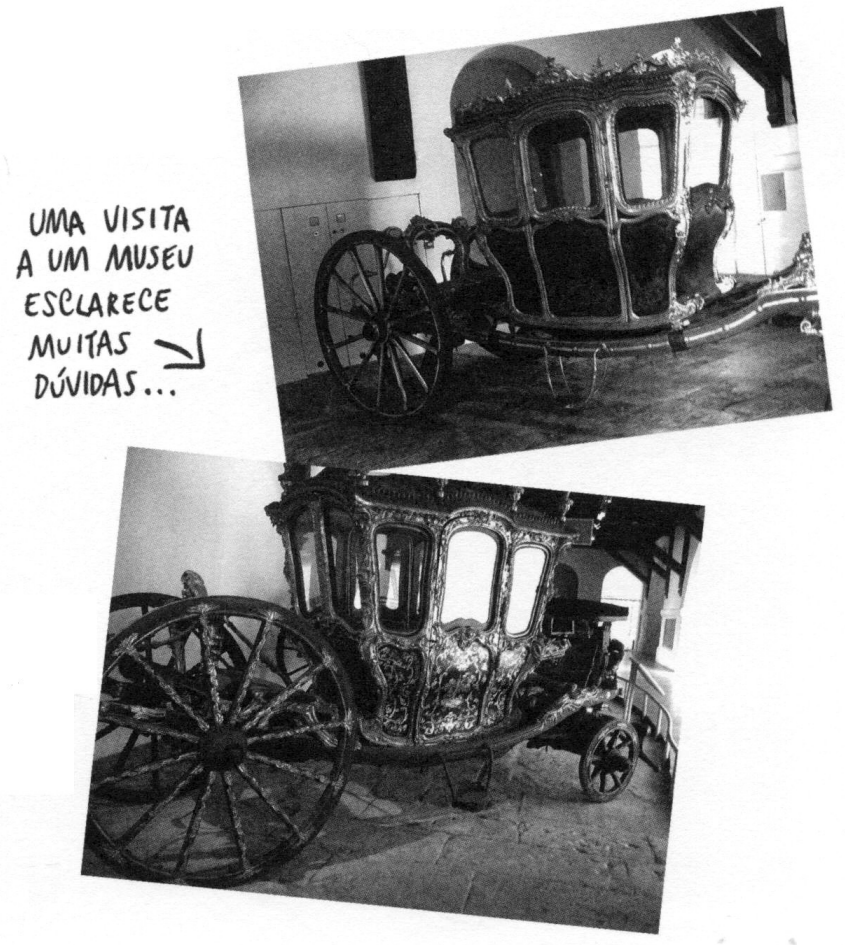

Figura 52 (SCHWARCZ; SPACCA, 2007, p. 89)

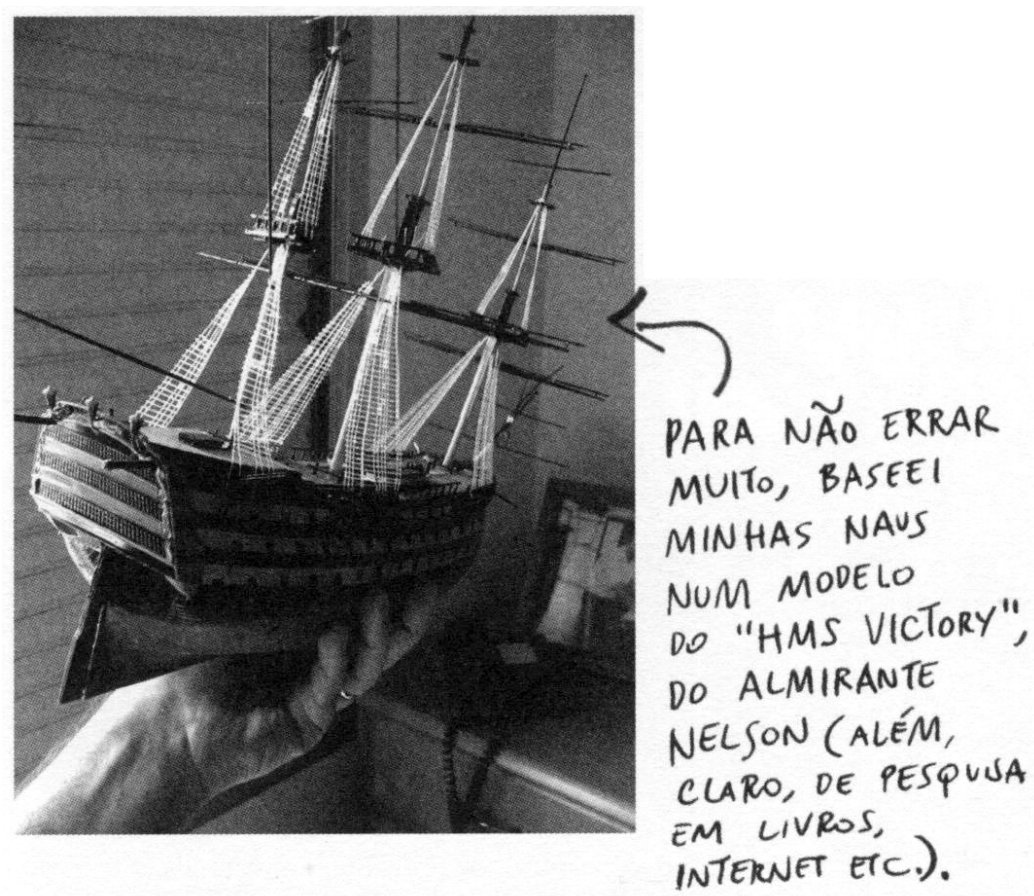

Figura 53 (SCHWARCZ; SPACCA, 2007, p. 88) 


\section{CONCLUSÃO}

O conhecimento histórico pode assumir as mais variadas formas quadrinísticas. Vimos que as histórias em quadrinhos vêm se inserindo paulatinamente na comunicação da cultura histórica brasileira, especialmente pela via escolar. Com políticas de fomento público a sua produção, é cada vez maior o acesso ao meio que já é uma forma de arte eminentemente comunicacional. Com sua maior inserção cresce também seu potencial comunicativo, isto é, de fazer uma cultura comum ao maior número de pessoas possível.

Vimos como os quadrinhos históricos se relacionam com outras formas de arte que visam à comunicação da cultura histórica. Essas formas que lhes antecederam, tais como o romance e a pintura histórica, seguem sendo um modelo para entendermos os quadrinhos tanto naqueles recursos formais compartilhados quanto naqueles que lhes são exclusivos. É a partir dos usos anteriores do adjetivo "histórico" para designar formas artísticas que representam a história que buscamos legitimar a configuração de um gênero quadrinístico específico.

As outras formas artísticas servem não apenas de modelo formal, mas também como fonte histórica. Esse é um dos grandes diferenciais do quadrinho didático-histórico, que, para comunicar conhecimentos históricos, antes de lhes dar forma quadrinística, precisa produzilos. Nesse âmbito surgem os problemas relativos aos campos de atuação da arte e da ciência na produção e comunicação do conhecimento. Nesse âmbito o locus acadêmico, por conta de sua especialização produtiva de conhecimento histórico, é de onde partem iniciativas que visam comunicar o conhecimento produzido. Os quadrinhos didático-históricos que estudamos são, nesse sentido, produtos científicos, artísticos e comunicativos que rompem fronteiras de difícil transposição.

Entre a pesquisa histórica e sua formatação quadrinística surge ainda uma série de problemas cuja identificação apenas iniciamos. Sua solução, porém, é das mais complexas e nesse quesito ainda há muito a ser pesquisado. São questões de ordem estética e epistemológica muito delicadas e envolvidas em muitas confusões. Tais confusões devem-se particularmente a diatribes teóricas as quais apresentamos apenas em suas linhas gerais. Problemas de forma e conteúdo; particularidade e universalidade; objetividade e subjetividade; factualidade e ficcionalidade, etc. estão além da alçada de nosso trabalho. 
Todavia, a identificação dos mesmos se faz necessária justamente para abrir caminho no sentido de melhores resoluções. Cremos, todavia, que o alcance de uma satisfatória superação de tais problemáticas transcende sua teorização e possui suas implicações mais delicadas justamente na prática didático-histórica. É na práxis comunicacional do conhecimento histórico, seja ela quadrinística, acadêmica, escolar, etc., que a clareza de seus impasses se faz mais necessária. Esse é, em grande medida, o objetivo da explanação teórica e da crítica didático-histórica que empreendemos. Se não demos conta de toda sua complexidade, esperamos ao menos ter lançado alguma luz sobre o acidentado terreno.

$\mathrm{Na}$ análise empírica dos quadrinhos que nos serviram de objeto pudemos observar maior ou menor grau de fundamentação em pesquisa histórica. Esta segue sendo uma tarefa que requer rigor metodológico. Tal rigor, entretanto, não se restringe à pesquisa positivista $\mathrm{e}$ colecionista, que se faria notar em uma certa erudição voltada a satisfazer à curiosidade na representação visual do passado. Este vai além da conhecimento positivo sendo superado pela crítica documental. Neste quesito encontramos no caso de André Toral um exemplo de como esta crítica pode se fazer presente na própria formatação quadrinística ao representar, mediante narrativa contextualizadora, os próprios usos e funções da cultura material e a construção social dos documentos enquanto monumentos.

A relação de produção dos quadrinhos didático-históricos, especialmente daquela mais próxima da produção científica do conhecimento segundo seus métodos institucionalizados, também pode se dar de diferentes maneiras. Vimos três casos diferentes nesse sentido, e em seus resultados podemos notar algumas implicações dessas diferenças no modo como são produzidas tais obras. Observamos, no caso da obra de André Toral, um autor simultaneamente historiador e quadrinista, que empreendeu tanto as etapas de pesquisa histórica quanto de sua formatação quadrinística. Já no caso das obras da coleção Redescobrindo o Brasil e D. João Carioca observamos um sistema de produção colaborativo entre as especializações artística e científica. Entre um sistema e outro, pudemos notar que a colaboração entre diferentes loci, como ocorre na coleção Redescobrindo (...), não se dá sem um certo prejuízo da forma quadrinística, especialmente no que se refere a uma de suas maiores especificidades que é a unidade narrativa no uso dos textos verbal e visual. Nas duas outras obras de quadrinhos históricos, em que a formatação quadrinística do conhecimento é centrada no trabalho do autor de quadrinhos, há uma melhor equação no uso de seus recursos linguísticos. 
Tivemos a oportunidade de observar também notáveis diferenças formais entre os casos estudados. Tais diferenças se referem justamente à variedade de formas que os quadrinhos podem assumir na comunicação didático-histórica. Tal variedade provém principalmente dos hibridismos que na formação da linguagem das historias em quadrinhos seguiu diferentes caminhos em diálogo com recursos de outras formas de arte. Adiós Xamigo (...) dialoga especialmente com o romance e a pintura histórica, não apenas na forma quadrinística mas também na pesquisa histórica. Dialoga com a literatura principalmente na continuidade de uma tradição quadrinística dedicada a narrativas aprofundadas, que possui atualmente no romance gráfico sua expressão mais destacada. A coleção Redescobrindo dialoga com a caricatura e com o cartunismo, remontando a uma tradição das mais embrionárias dos quadrinhos que é a da imprensa ilustrada. D. João Carioca, por sua vez, pode ser visto como uma mistura de ambos os casos, remetendo tanto à caricatura quanto ligando-se ao romance gráfico. Outra diferença notável nas formas de se representar a história em ambos os casos se dá na vinculação a gêneros ainda mais antigos no tempo: o trágico e o cômico. Talvez resida nessa diferença primordial no tom da narrativa histórica a função mais elementar de atribuição de sentido humano à história.

Tais particularidades formais possuem, portanto, implicações na própria percepção sensível e apreensão cognitiva do conhecimento histórico. Por meio do quadrinho histórico de Toral e de Schwarcz e Spacca podemos ver o passado em sua reconstituição vívida, saltandonos aos olhos desde a riqueza de detalhes que emerge da representação da cultura material ou fazendo-nos sentir mais intensamente como seus personagens podem ter experienciado certos processos históricos. Por meio do cartunismo histórico da coleção Redescobrindo o Brasil, a síntese esquemática do conhecimento histórico é ilustrada de forma que seus significados são carregados, no recurso à caricatura, de crítica política. Tais usos e funções da arte na comunicação histórica não são exclusividade dos quadrinhos. A forma como se efetivam é.

Concluímos, por fim, que os quadrinhos são uma forma das mais interessantes para comunicar o conhecimento histórico. Primeiro, por seu alcance social. Sua inserção na vida de milhares de brasileiros vem se realizando com cada vez mais intensidade, especialmente através de políticas públicas de inclusão do meio nas bibliotecas escolares. Segundo, por suas qualidades formais. A linguagem dos quadrinhos demandam uma leitura diferenciada e pode comunicar a história de forma simultaneamente visual e verbal. Esses dois fatores, em 
especial, apontam para a direção de uma promissora tendência ao desenvolvimento do gênero do quadrinho histórico e de suas potencialidades didático-históricas. Para tanto, entretanto, os sujeitos envolvidos nesse processo devem assumir as responsabilidades artísticas e científicas que lhes competem. Para que os quadrinhos possam comunicar cada vez mais e melhor o conhecimento histórico, arte e ciência devem estar em comum acordo. Tal comunhão pode, e muito bem, fazer-se nos quadrinhos. 


\section{BIBLIOGRAFIA}

ADORNO, Theodor. Teses sobre sociologia da arte. In: Theodor W. Adorno. São Paulo: Ática, 1986. (Coleção Grandes Cientistas Sociais, n. 54)

ADORNO, Theodor; HORKHEIMER, Max. Dialética do esclarecimento: fragmentos filosóficos. Rio de Janeiro: Jorge Zahar, 1985.

ALBIERI, Sara; GLEZER, Raquel. O campo da história e as "obras fronteiriças": algumas observações sobre a produção historiográfica brasileira e uma proposta de conciliação. Revista IEB, n. 48, 2009.

ANDERSON, Perry. Trajetos de uma forma literária. Revista Novos estudos, $n$. 77, mar./2007.

ANGELI; SCHWARCZ, Lilia Moritz. Cai o Império!: República, vou ver! São Paulo : Brasiliense, 1995

BARBOSA, Alexandre. Os quadrinhos no ensino de artes. In: RAMA, A.; VERGUEIRO, W. (Org.). Como usar as histórias em quadrinhos em sala de aula. São Paulo: Contexto, 2007.

BARBOSA, Alexandre. Histórias em quadrinhos sobre a História do Brasil em 1950: a narrativa dos artistas da EBAL e outras editoras. (Dissertação em Ciências da Comunicação) São Paulo: ECA/USP, 2006.

BENJAMIN, Walter. Alegoria e drama barroco. In: Documento de cultura, documento de barbárie. São Paulo: Editora Cultrix/Edusp, 1985.

BENJAMIN, Walter. Magia e técnica, arte e política: ensaios sobre literatura e história da cultura. São Paulo: Brasiliense, 1995.

BENJAMIN, Walter. The work of art in the age of its technological reproducibility, and other writings on media. Cambridge: Harvard University Press, 2008.

BONIFACIO, Selma de Fatima. História e (m) Quadrinhos: análises sobre a História ensinada 
na arte seqüencial. (Dissertação em Educação). Curitiba: UFPR, 2005

BURKE, Peter. Testemunha ocular: história e imagem. Bauru: EDUSC, 2004.

BURKE, Peter; MENESES, Ulpiano Bezerra (Org.). O imaginário e o poético nas Ciências Sociais. Bauru: EDUSC, 2005.

CARDOSO, Oldimar. Para uma definição de Didática da História. Revista Brasileira de História, v. 28, n. 55, 2008.

CHIAVENATTO, Júlio José; PAIVA, Miguel. Olha lá o Brasil! : e finalmente Portugal nos descobriu. São Paulo : Brasiliense, [198-]

CIRNE, Moacy. Para ler os quadrinhos: da narrativa cinematográfica a narrativa quadrinizada. Petrópolis: Vozes, 1975.

CIRNE, Moacy. Uma introdução política aos quadrinhos. Rio de Janeiro: Achiamé/Angra, 1982.

DORFMANN, MATTELLART. Para ler o Pato Donald. Rio de Janeiro: Paz e Terra, 1978

ECO, Umberto. Apocalípticos e integrados. São Paulo: Perspectiva, 1993.

EISNER, Will. Quadrinhos e arte seqüencial: a compreensão e a prática da arte mais popular do mundo. São Paulo: Martins Fontes, 2001.

FERRO, Marc. Cine y Historia. Barcelona: Editorial Gustavo Gili, 1980.

FONSECA, Joaquim T. Benicio da. Caricatura: a imagem gráfica do humor. Porto Alegre: Artes e Oficios, 1999.

GAGNEBIN, Jeanne Marie. História e narração em Walter Benjamin. São Paulo: Perspectiva, 2008. $2^{\mathrm{a}}$ ed.

GONÇALO JR. A guerra dos gibis.São Paulo: Cia das Letras, 2004.

GUAZZELLI, Cesar Augusto Barcellos. Visões do passado na história em quadrinhos. Revista Vidya. v. 19, n. 33, jan./jun. 2000, p. 141160.

GUAZZELLI, Eloar. Canini e o anti-herói brasileiro: do Zé Candango ao Zé - realmente - 
Carioca. (Dissertação em Ciências da Comunicação) São Paulo: ECA/USP, 2009.

HOBSBAWM, Eric. Sobre história: ensaios. São Paulo: Companhia das Letras, 1998.

JAMESON, Frederic. O romance histórico ainda é possível? Revista Novos estudos, v. 77, mar. 2007.

LE GOFF, Jacques. Memória e História. Campinas: Ed. UNICAMP, 1990.

LUKÀCS, György. Introdução a uma estética marxista: sobre a categoria da particularidade. Rio de Janeiro: Editora Civilização Brasileira, 1968.

LUKÁCS, György. The historical novel. Lincoln: University of Nebraska Press, 1983.

LUKÁCS, György. Marxismo e teoria da literatura. São Paulo: Expressão Popular, 2010.

PAIVA, Miguel; SCHWARCZ, Lilia Moritz. Da Colônia ao Império: um Brasil pra inglês ver... São Paulo: Brasiliense, [198-].

RAMOS, Paulo; VERGUEIRO, Waldomiro (Org.). Quadrinhos na educação: da rejeição à prática. São Paulo: Contexto, 2009.

RAMOS, Paulo. A leitura dos quadrinhos. São Paulo: Contexto, 2009.

RAMOS, Paulo. Álbum de André Toral mostra relação histórica com os indios. 2009. In: http://blogdosquadrinhos.blog.uol.com.br/entrevista/arch2009-04-01_2009-04-30.html

(Postado em: 30/04/2009; acesso em jul./2012).

RÜSEN, Jörn. História viva: teoria da história : formas e funções do conhecimento histórico. Brasília: Editora Universidade de Brasília, 2007.

SANTOS, Roberto Elísio dos; VERGUEIRO, Waldomiro. A pesquisa sobre histórias em quadrinhos na Universidade de São Paulo: análise da produção de 1972 a 2005. UNIrevista, v. 1, n. 3, jul. 2006 .

SCHWARCZ, Lilia Moritz; SPACCA. D. João Carioca: a corte portuguesa chega ao Brasil (1808-1821). São Paulo: Companhia das Letras, 2007.

SILVA, Marcos. Além das coisas e do imediato: cultura material, História imediata e ensino 
de História. Tempo, v. 11, n. 21, jul./2006, p. 82-96.

TORAL, André Amaral de. O Negócio do Sertão (como descolar uma grana no séc. XVII). São Paulo: Graphic Dealer Editora, 1991.

TORAL, André Amaral de. Adiós, Xamigo Brasileño: um estudo sobre a iconografia da guerra da Tríplice Aliança com o Paraguai (1864-1870). (Tese em História Social). FFLCH/USP, 1997.

TORAL, André. Adeus, chamigo brasileiro: uma história da Guerra do Paraguai. São Paulo: Companhia das Letras, 1999a.

TORAL, André Amaral de. A Guerra no Mercosul. Revista Superinteressante, v. 13, n. 9, 1999b.

TORAL, André Amaral de. Imagens em Desordem: a iconografia da Guerra do Paraguai. São Paulo: Humanitas/FFLCH/USP, 2001.

TORAL, André Amaral de. Os brasileiros. São Paulo: Conrad Editora do Brasil, 2009. TORAL, André Amaral de. Curtas e Escabrosas. São Paulo: Devir, 2011. VERGUEIRO, Waldomiro. Os quadrinhos nas aulas de história: uma empreitada que exige cuidado. Disponível em: http://omelete.uol.com.br/quadrinhos/os-quadrinhos-nas-aulas-dehistoria-uma-empreitada-que-exige-cuidados/. (Postado em: outubro de 2003; acesso em jul./2012).

VERGUEIRO, Waldomiro. A linguagem dos quadrinhos: uma alfabetização necessária. In: RAMA, A.; VERQUEIRO, W. (Org.). Como usar as histórias em quadrinhos na sala de aula. São Paulo: Contexto, 2004, p. 31-64.

VERGUEIRO, Waldomiro. História em quadrinhos: seu papel na indústria de comunicação de massas. (Dissertação de Mestrado em Ciências da Comunicação), São Paulo: ECA/ USP, 1985.

VERGUEIRO, Waldomiro. As histórias em quadrinhos no limiar de novos tempos: em busca 
de sua legitimidade como produto artístico e intelectualmente valorizado. Visualidades: Revista do Programa de Mestrado em Cultura Visual, v. 5, n. 1, 2007.

WILLIAMS, Raymond. Base e superestrutura na teoria cultural marxista. Revista USP, v. 65, mar./maio 2005, p. 210-224.

WILLIAMS, Raymond. Palavras-chave: um vocabulário de cultura e sociedade. São Paulo: Boitempo, 2007.

WITEK, Joseph. Comic books as History: the narrative art of Jack Jackson, Art Spiegelman, and Harvey Pekar. Jackson : University Press of Mississipi, 1989. 